AGUSTINA, JOSÉ R. "Fenomenología del employee crime: Bases para definir

Estrategias de prevención del delito intraempresarial".

Polít. crim. Vol. 5, No 10 (Diciembre 2010), Art. 3, pp. 352-409.

[http://www.politicacriminal.cl/Vol_05/n_10/Vol5N10A3.pdf]

\title{
Fenomenología del employee crime: \\ Bases para definir estrategias de prevención del delito intraempresarial
}

\author{
José R. Agustina \\ Profesor de Criminología y Derecho Penal \\ Universitat Internacional de Catalunya \\ (Barcelona, España) \\ jragustina@uic.es
}

\begin{abstract}
Resumen $^{1}$
Hasta hace apenas unos años, el impacto económico derivado de la delincuencia intraempresarial no era objeto de análisis de forma rigurosa y sistemática. Sin duda, el interés creciente por cuantificar el coste económico a escala nacional del delito de los trabajadores, de modo particular en las economías de Estados Unidos y del Reino Unido, ha espoleado la investigación criminológica sobre la delincuencia y la desviación dentro de la empresa y las organizaciones.
\end{abstract}

En el presente artículo se expone una radiografía general de la forma de ser o fenomenología de los delitos (y otras conductas desviadas) que se cometen en el contexto empresarial. La tesis de fondo es que un conocimiento en profundidad de las particularidades propias del employee crime, de las relaciones entre perfiles laborales y perfiles criminológicos, así como de los condicionantes situacionales que pueden facilitar la aparición de conductas ilícitas en la empresa, constituye la premisa básica que debe tenerse en consideración para definir adecuadas estrategias de prevención y control por parte del empresario.

\section{Palabras clave}

Delito intraempresarial, estrategias de prevención del delito en la empresa, criminlogía aplicada a la empresa, privacidad versus prevención del delito, límites ético-jurídicos en la prevención del delito.

\begin{abstract}
Just a little time ago, the economic impact deriving from crime within organisational business settings was not a matter of study, at least of a rigorous and systematic one. No doubt, the increasing interest for quantifying employee crime economic costs, particularly in American and British national economies, has promoted criminological research on criminality within business organisations. In this paper, a portrait of employee crime and other deviant conducts perpetrated within a company in a particular way arises because of the context. For defining crime prevention and control strategies in this field it is crucial to get radical knowledge on employee crime

\footnotetext{
1 Con algunas modificaciones, en estas líneas se condensa buena parte de lo ya expuesto en AGUSTINA SANLLEHÍ, J.R., El delito en la empresa, Atelier: Barcelona, 2010, obra que recoge, con las debidas adaptaciones, la introducción a mi tesis doctoral, defendida en la Universidad Pompeu Fabra en 2008 y dirigida por Jesús M. SILVA SÁNCHEZ.
} 
AGUSTINA, JOSÉ R. “Fenomenología del employee crime: Bases para definir Estrategias de prevención del delito intraempresarial".

phenomenology; the relations between occupational profile and crime profile; and the situational factors that may facilitate the appearance of crime within organisational settings.

\title{
Key words
}

Employee crime, insider crime, crime prevention strategies in business organisational settings, applied criminology on business, privacy versus crime prevention, ethical and legal boundaries in crime prevention.

\section{Introducción: perspectiva de análisis para definir adecuadamente las estrategias de prevención del employee crime}

\begin{abstract}
"What is the problem? The problem is occupational crime and other abusive employee behavior characterized by illegal, unethical, and irresponsible acts. Such behavior exists at all levels -from the highest-ranking levels of executive management to rock-bottom subordinate positions. And while private sector interests are often perceived as the most egregious violators, the problem is not unique to business. The reality is that our government and our most trusted institutions are not immune to the problem and suffer from the same behaviours". ${ }^{2}$
\end{abstract}

Hasta hace apenas unos años, el impacto económico derivado de la delincuencia intraempresarial (o dentro de la empresa y, en sentido lato, de las organizaciones) apenas era objeto de análisis, al menos de un estudio riguroso y sistemático. La Criminología había centrado sus esfuerzos en los delitos de sangre. La realidad intramuros que tenía lugar dentro de los límites de la empresa permanecía en la esfera privada por distintos motivos que, sin duda, guardan relación con la posición de fuerza del empresario. ${ }^{3}$ Sin duda, el interés creciente por cuantificar el coste económico a escala nacional del delito de los trabajadores, de modo particular en las economías de Estados Unidos y del Reino Unido, ha espoleado la investigación criminológica sobre la delincuencia y la desviación dentro de la empresa y las organizaciones.

En el presente artículo trataré de exponer una radiografía general de la forma de ser o fenomenología de los delitos y otras conductas desviadas que se cometen en el

\footnotetext{
${ }^{2}$ BLOUNT, E.C., Occupational Crime, 2003, p. 1.

${ }^{3}$ Para un análisis en profundidad de las causas puede verse AGUSTINA SANLLEHÍ, J.R., "Estrategias de reacción frente al delito. A propósito del delito intraempresarial", Revista de Derecho Penal y

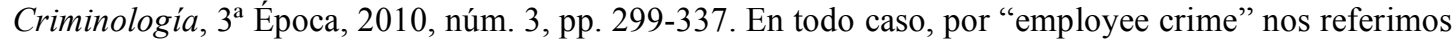
a aquellos delitos perpetrados por los empleados o trabajadores en el seno de la empresa de los que, en principio, no se beneficia la propia empresa, siendo por el contrario ésta misma la principal perjudicada, directa o indirectamente. A este respecto, por contraste es interesante resaltar la introducción en la reforma 5/2010 del Código Penal Español del nuevo art. 31 bis, en el que se incluyen conductas de los empleados que se incardinarían en la categoría de corporate crime: en éstos la conducta debe realizarse en provecho de la persona jurídica, siendo patente la diferencia entre employee crime y corporate crime, a pesar de que en ambos participen empleados o trabajadores.
} 
contexto empresarial. Un conocimiento en profundidad de las particularidades propias del employee crime, de las relaciones entre perfiles laborales y perfiles criminológicos, así como de los condicionantes situacionales que pueden facilitar la aparición de conductas ilícitas en la empresa, constituye la premisa básica que debe tenerse en consideración para definir adecuadas estrategias de prevención y control por parte del empresario. La identificación de sus causas y la descripción de sus manifestaciones propias persiguen construir una teoría general descriptiva que, ahondando en la naturaleza de los problemas y conflictos que surgen en la empresa cuando se produce un quebranto en las expectativas mutuas (entre trabajadores y empresarios o responsables), ayude en la tarea de prevenir, detectar y erradicar las conductas ilícitas en el contexto de nuestro estudio. Una mayor comprensión de las causas y factores del employee crime (desde un enfoque antropológico hasta un análisis situacional, pasando por la atmósfera particular de cada empresa) nos permitirá afrontar, en cada contexto particular, un enfoque preventivo a medida del perfil del trabajador, sus circunstancias y su entorno.

Con este trabajo se pone de manifiesto, una vez más, la importancia de un adecuado análisis criminológico como estrategia de prevención y resolución de conflictos. En la mayoría de los problemas dentro de las organizaciones, el Derecho penal llega tarde e irrumpe de forma desproporcionada en el interior de la empresa. El principio de ultima ratio no puede ser una invocación genérica que justifique la no intervención y lleve a no hacer nada ante injustos de bagatela. En efecto, sólo desde un enfoque complementario de las herramientas penales y criminológicas se puede llenar de contenido operativo ese principio limitador de la intervención penal.

\section{Entorno y delito en la criminalidad dentro de la empresa}

El punto de partida de estas reflexiones se sitúa en la empresa en cuanto contexto de relación y convivencia entre las personas. Las interacciones humanas que tienen lugar en el entorno empresarial generan, por sus propias motivaciones y particularidades, una delincuencia con unas características específicas, que de algún modo guarda relación con ese entorno. Tal delincuencia particular de la empresa, que surge y se desarrolla en la empresa y desde la empresa, refleja en su modus operandi-aunque pueda objetarse que lo hace de forma limitada- la lógica del mundo empresarial y los códigos de conducta que el modo de ser de la empresa imprime en quienes en ella se relacionan. ${ }^{4}$

En realidad, el análisis de cualquier fenómeno delictivo -la delincuencia empresarial no es una excepción a este respecto- no puede disociarse del contexto en el que el hecho criminal surge y se desarrolla. Una de las aportaciones más significativas de la Escuela de Chicago al estudio criminológico del delito consistió en resaltar la importancia de la específica valoración de los distintos ambientes en los que se desarrolla la vida social del individuo para comprender el significado de su

\footnotetext{
${ }^{4}$ Del modo de ser de la empresa (la cultura dominante en su seno, las pautas de organización, las expectativas profesionales de cada agente, etc.) se deriva en parte su modo de obrar ('operari sequitur esse ). Sin entrar en el análisis de la aplicabilidad de este principio tomista al ámbito empresarial, sin duda la descripción general del modo de ser de la empresa proporciona claves de explicación del delito que tiene lugar en su interior.
} 
AGUSTINA, JOSÉ R. “Fenomenología del employee crime: Bases para definir Estrategias de prevención del delito intraempresarial".

comportamiento. ${ }^{5}$ En tal sentido, los delitos perpetrados en el contexto de la empresa y las relaciones laborales -aunque pueda tratarse de delitos comunes no específicos del ámbito empresarial- reflejan unos patrones delictivos en parte sólo específicos del entorno en el que se desarrollan. El descubrimiento de tales patrones se logra en la medida en que se identifica la adecuada relación entre factores ambientales y delito, tarea no exenta de dificultades de todo orden.

En tal sentido, un factor significativo en el modo de interactuar entorno y persona en el ámbito empresarial se refiere a la dimensión organizacional de la empresa. Así por ejemplo, el hecho de tratarse de una corporación en la que trabaja un número importante de personas, frente a la pequeña y mediana empresa, tiene consecuencias directas en las oportunidades delictivas que se generan y en los mecanismos de control que -según los recursos financieros de cada empresa- se implementan en la vigilancia de los trabajadores, estructurando su espacio de actuación. La ausencia de controles y la atmósfera de anonimato, como se verá, son elementos criminógenos relevantes que están relacionados directamente con el entorno inmediato del trabajador. ${ }^{6}$

Evidentemente, dentro del contexto de la delincuencia empresarial también influyen otros factores individuales y sociológicos -las características individuales de las personas, su nivel económico, la formación recibida, su adaptación social-. Así, el tipo de delincuencia guarda una relación muy significativa con el status económico de la persona. Y la posición que ésta ocupa en la estructura económica determina las oportunidades, facilidades y posibilidades para cometer delitos específicos. ${ }^{7}$ En este sentido, se afirma que una persona de bajo nivel económico no puede ordinariamente cometer delitos de cuello blanco. No obstante, lo que se quiere resaltar en este momento es que, al margen de las consideraciones individuales que se puedan realizar desde distintas perspectivas, nuestro análisis del delito parte de la relevancia de los factores estructurales y organizacionales del entorno empresarial.

Sin embargo, también se debe advertir que, lógicamente, el contexto no simplifica ni homogeneiza la clase de delitos que tienen lugar en su campo de referencia. El fenómeno de la criminalidad empresarial es ciertamente muy amplio. En su seno, entre otras posibles clasificaciones, se pueden distinguir aquellos comportamientos dirigidos contra bienes jurídicos de la propia empresa, esto es, lo que puede denominarse la "criminalidad intra-empresarial" o ad intra (Betriebskriminalität), de aquéllos que constituyen delitos contra bienes jurídicos de terceros, esto es, la "criminalidad empresarial hacia fuera" o ad extra (Unternehmenskriminalität). ${ }^{8}$

\footnotetext{
${ }^{5}$ Vid. MClaUghlin, E., MUNCIE, J., The Sage Dictionary of Criminology, 2007, p. 39, donde resalta que la Escuela de Chicago, al poner el centro de atención en las causas ambientales del delito, puso en entredicho la creencia de que la criminalidad era el resultado de factores biológicos innatos así como patológicos (causas individuales).

${ }^{6}$ De acuerdo con los datos estadísticos de la U.S. Small Business Administration, la pequeña empresa representa el $99.7 \%$ del número de empresas en el mercado; tiene contratado alrededor del $50 \%$ de los trabajadores del sector privado; genera el $51 \%$ del producto interior bruto del sector privado; y en la última década ha contribuido con la creación de entre el 60 y el $80 \%$ de los nuevos puestos de trabajo.

${ }^{7}$ Vid. SUTHERLAND, E.H., Principles of Criminology, 1939, p. 177.

8 Vid. PASTOR MUÑOZ, N., La respuesta adecuada a la criminalidad de los directivos, 2006, p. 3. La criminalidad de empresa (Unternehmenskrimimalität), en palabras de Schünemann, comprende los delitos económicos en los que "por medio de la actuación de una empresa se lesionan bienes jurídicos e intereses externos, incluidos los bienes jurídicos e intereses propios de los colaboradores de la
} 
Podrían establecerse ciertos nexos de unión entre ambas, y estudiar si en algunos supuestos lo que al principio sólo tenía manifestaciones en la criminalidad ad intra ha derivado posteriormente en criminalidad ad extra. Habría que investigar si-como parece a priori más lógico- en el ámbito de la empresa los individuos tienden a cometer delitos primeramente en su más inmediato y cercano ámbito de actuación. ${ }^{9} \mathrm{Si}$ se verificase que la comisión de delitos ad intra viene facilitada, entre otros factores, por la ausencia de controles internos en la empresa, ello podría tener algún efecto criminógeno en la criminalidad ad extra. Es tan sólo una hipótesis que habría que contrastar empíricamente, pero por lo que aquí interesa, si se confirmara que la empresa que comienza teniendo criminalidad ad intra acabará produciendo delitos que revertirán en bienes jurídicos de terceros ajenos a la empresa, los efectos multiplicadores de la criminalidad intraempresarial deberían analizarse con sumo interés.

Por otro lado, cualquier delito que tiene origen en la empresa, aunque la víctima principal se sitúe más allá del ámbito interno de la misma -ya se trate de un cliente, un consumidor o un tercero-, tiene siempre efectos "ad intra". Es decir, en tanto que el patrimonio empresarial puede acabar respondiendo del daño cometido por uno de sus agentes, sobre el empresario recaen deberes de control. La empresa considerada como bien jurídico colectivo (concepción patrimonialista) y desde un punto de vista comunitarista (comunidad de personas) se resiente ante la comisión de un hecho delictivo que procede de su interior.

Pues bien, será el punto de vista propio de la "criminalidad intra-empresarial" o ad intra la perspectiva que principalmente adoptaremos en líneas subsiguientes. El motivo de acotar de este modo el campo de estudio se fundamenta en la intención de profundizar en las relaciones existentes entre confianza y control en orden a clarificar las posiciones de responsabilidad de cada uno de los intervinientes. Esta criminalidad ad intra se basa en un conjunto de reglas internas de obligación y responsabilidad que son el modo de relación entre los individuos que conforman la comunidad empresarial. La dinámica de tales relaciones se fundamenta en las expectativas de confianza y, concretamente, en el valor de la lealtad. El quebrantamiento de tales vínculos constituirá un flujo delictivo bi-direccional que pondrá en peligro la existencia misma de la empresa, ya sea por medio del delito del trabajador o del delito del empresario.

Sin embargo, conviene realizar una última e importante aclaración previa que nos conduzca a establecer una clasificación preliminar, distinción que será relevante a lo largo de las próximas líneas. En el seno de la criminalidad en la empresa, los delitos que se cometen por cualquiera de sus miembros tienen indefectiblemente al menos una víctima en todos los casos: la propia empresa. En efecto, la persona física del

empresa", mientras que la criminalidad en la empresa (Betriebskriminalität) se refiere a los comportamientos lesivos de "colaboradores de la empresa a la misma o a otros de sus colaboradores". (vid. SCHÜNEMANN, B., "Cuestiones básicas de dogmática jurídico-penal”, ADPCP, 1988-II, trad. Bruckner y Lascuraín, pp. 530-531).

${ }^{9}$ El estudio, en este sentido, de las correlaciones relativas a si el delincuente tiende a iniciarse en un lugar que conoce se relaciona y se puede ubicar en el contexto de las investigaciones en torno al concepto criminológico de espacio defendible (defensible space) y la geografía del delito (geographies of crime). vid., al respecto, MCLAUGHLIN/MUNCIE, The Sage Dictionary, cit. nota ${ }^{\circ}$ 5, pp. 115116 y $185-186$, respectivamente. 
AGUSTINA, JOSÉ R. "Fenomenología del employee crime: Bases para definir Estrategias de prevención del delito intraempresarial".

administrador o directivo -es decir, el garante que puede y debe ejercer, conforme al rol asignado a su cargo o a su posición en la estructura organizacional, el dominio del riesgo- puede considerarse en cierto sentido una víctima indirecta o, cuando menos, un sujeto pasivo del delito. Es más, en algunos escenarios delictivos en los que el delito del subalterno debiera haber sido evitado por el garante, éste puede llegar a convertirse -en virtud de la imputación de responsabilidad por omisión de sus funciones de prevención y control- en sujeto responsable por comisión omisiva imprudente. Por este motivo, el garante no sólo protege a la empresa sino a su propia persona, manteniéndose a salvo de imputársele una omisión negligente por su parte, respecto de las conductas de aquellas personas encomendadas a su cargo.

\section{Factores criminógenos en el entorno empresarial}

Desde una perspectiva general, sin referirse propiamente a un específico delito del trabajador (employee crime), algunos autores han distinguido tres posibles modelos para explicar el delito: ${ }^{10}$ (1) el modelo del delincuente racional (rational cheater model), que vendría a explicar la comisión del delito por parte del trabajador-como también el control delictivo por parte del empresario-, de acuerdo con el conocido cálculo coste-beneficio; (2) el modelo de la acción consciente (conscience model), defendido desde una perspectiva criminológica, que concibe el delito como la ausencia en la persona del delincuente del suficiente grado de preocupación o afectación por su actuación ilegal; y (3) desde el punto de vista psicológico, el modelo de la acción bajo el control del impulso (impulse control model), en la que la inmediatez de las ganancias que se obtienen al cometer el delito tiene mayor peso que el coste potencial de la pena de mayor duración. ${ }^{11}$

Sin embargo, la criminalidad empresarial posee particularidades propias que conviene tener presente. Como pusieron de manifiesto Marcus Felson y Ronald Clarke (1997), "something new is needed to bridge this gap", en referencia al escaso interés prestado hasta el momento por la literatura criminológica en el estudio de la relación entre delito y empresa. El nacimiento de un nuevo campo de investigación empírico en torno a la criminalidad en la empresa ha comenzado a despertar interés tanto desde el sector público, como desde el propio ámbito empresarial, sin duda por la conciencia cada vez mayor de las repercusiones de este tipo de delincuencia en la economía de la empresa y en el progreso de la sociedad. ${ }^{12}$

Se pueden enumerar diferentes razones por las que no conviene en absoluto despreciar la relevancia del entorno laboral para el análisis criminológico y criminógeno de la persona y su entorno (ofender/context relationship). ${ }^{13}$ En términos comparativos, el lugar de trabajo puede considerarse el contexto de relación en el que la persona adulta se desenvuelve durante más tiempo. En este sentido, es en el

\footnotetext{
${ }^{10}$ Cfr. al respecto, NAGIN, D.S., PATERNOSTER, R., REBITZER, J.B., SANDERS, S., TAYLOR, L.J., "Monitoring, motivation, and management: the determinants of opportunistic behaviour in a field experiment", American Economic Review N 92 (2002), pp. 850-873.

${ }^{11}$ Cfr. al respecto, RICKMAN, N., WITT, R., "The Determinants of Employee Crime in the UK", Economica $\mathrm{N}^{\circ} 74$ (2007), p. 162.

12 Vid. FELSON, M., CLARKE, R.V., Business and Crime Prevention, 1997, pp. 1-3, en donde justifican el interés objetivo por ese estudio: "crime is an essential topic for business because it threatens profits while interfering with business goals and relations to a larger society".

${ }^{13}$ WILLISON, R., "Understanding the perpetration of employee computer crime in the organizational context", Information and Organization $\mathrm{N}^{\circ} 16$ (2006), pp. 304-324.
} 
contacto diario con su entorno laboral y la cultura imperante en su lugar de trabajo donde el individuo adopta con facilidad -en ocasiones imperceptiblemente- pautas de conducta moralmente adecuadas o por el contrario desviadas. Tales referencias de valores se interiorizan de tal forma que pueden llegar a tener consecuencias difíciles de cuantificar aunque no por ello menos intensas y decisivas. El lugar de trabajo es, en este sentido, un significativo medio de socialización y de interiorización de códigos de conducta. Por otro lado, las particularidades y rasgos propios que caracterizan una profesión $\mathrm{u}$ oficio imprimen un influjo considerable en la personalidad del individuo, en sus hábitos de conducta y en sus precomprensiones, que pueden posteriormente manifestarse en una carrera delictiva (vid. infra la relación entre perfiles laborales y perfiles criminológicos).

Desde un punto de vista criminógeno, la ausencia de vínculos de integración social del trabajador respecto de la empresa, su falta de identificación con la compañía, la carencia de motivaciones positivas desde el punto de vista psicológico o emocional pueden considerarse una causa de su comportamiento delictivo. La empresa no deja de ser una comunidad de personas, una sociedad dentro de una sociedad, en la que a escala menor se aplican las teorías de los vínculos sociales (social bond theories). La importancia de los lazos personales e institucionales explica -de acuerdo con tales teorías- por qué algunos individuos cometen delitos mientras que la mayoría no lo hace. $^{14}$

A este respecto, una característica relevante en la descripción de las relaciones laborales entre los miembros de la comunidad empresarial se encuentra en la estructuración jerarquizada y el desequilibrio entre las distintas posiciones, en tanto se fundamentan en una manifiesta desigualdad entre las partes. Así, la posición de subordinación del trabajador respecto del empresario responde a una situación estructural de naturaleza económica, que tiene lugar en el microcosmos particular que es la empresa. En este sentido, es pacíficamente admitido que la existencia de comportamientos ilegales en el seno de la empresa se debe no tanto a la eventual predisposición personal de cada individuo, sino a factores estructurales como la división del trabajo, las relaciones jerárquicas o el sistema normativo interno. ${ }^{15}$ Es decir, en orden a explicar el delito en el ámbito empresarial es ciertamente relevante la posición que ocupa el individuo, el rol determinado que cumple dentro de la estructura organizacional.

Sin pretender simplificar en exceso la explicación del delito en la empresa -no se puede interpretar lo anteriormente expuesto como si la presión que ejerce la estructura empresarial fuera determinante en términos absolutos-, tampoco se puede desconocer la proclividad criminal que comportan determinados requerimientos de la producción. $\mathrm{O}$ el hecho de concentrarse en la persona del directivo facultades de decisión y disposición sobre los intereses de la empresa, terreno abonado para los abusos. ${ }^{16}$ Así, el trabajador goza necesariamente de ciertos espacios de confianza (por la propia imposibilidad de implementar un control omnicomprensivo), que pueden inducir a la

\footnotetext{
${ }^{14}$ BUSSMANN, K.-D., Causes of Economic Crime and the Impact of Values, 2003, p. 10.

${ }^{15}$ BAYlos GRAU, A., TERRADILlOS BASOCO, J., Derecho penal del trabajo, 1997, p. 40. Sin embargo, junto a tales factores estructurales se debería agregar siempre un factor personal adicional, como por ejemplo la sensación subjetiva de impunidad-independientemente de que esa percepción se apoye en una base real objetiva-.

${ }^{16}$ SÁNCHEZ ÁLVAREZ, M., Los delitos societarios, 1996, p. 34.
} 
AGUSTINA, JOSÉ R. “Fenomenología del employee crime: Bases para definir Estrategias de prevención del delito intraempresarial".

deslealtad, al abuso de la confianza otorgada. Como concluye Solivetti, no puede hablarse de sistema de coerción al crimen, mas no puede negarse la existencia de condiciones internas favorables a la génesis de actos ilícitos. ${ }^{17}$

Del mismo modo, factores organizacionales con incidencia en la motivación y psicología del trabajador pueden tener gran relevancia y ser un factor criminógeno contrastado. Así por ejemplo, una de las conclusiones de las investigaciones psicológicas sobre la delincuencia en la empresa revela la correlación entre una insuficiente justificación de recortes salariales (pay cuts) y el incremento de sustracciones en la empresa. $^{18}$

Tales peculiaridades de la relación laboral y de la organización empresarial no sólo explican la génesis del delito intraempresarial (dimensión criminógena), sino que también coadyuvan a entender la reacción contra la delincuencia: el funcionamiento de los procesos de criminalización (estrategias regulativas), la adopción de mecanismos de reducción de las oportunidades delictivas por parte del empresario (estrategias preventivas) y el estudio de las distintas posibilidades de reacción legal frente al delito (estrategias en la resolución de conflictos).

\section{Consideraciones en torno al análisis cuantitativo y cualitativo del delito intraempresarial}

La escasa investigación empírica y el menor interés criminológico en torno a los delitos en el lugar de trabajo (crime at work) responden a distintas causas. Tal vez, la misma confusión terminológica en torno al concepto de "white-collar crime" por parte de los penalistas y criminólogos sea un elemento expresivo de la ausencia del suficiente desarrollo y de la carencia de criterio en este ámbito delictivo. Con independencia de si se trata de una causa o una consecuencia del problema, la denominación empleada (delitos de cuello blanco) es cuanto menos desafortunada, y viene a oscurecer el conjunto de los delitos que supuestamente debería abarcar en su significado. ${ }^{19}$

Hasta hace apenas unos años, el impacto económico de la delincuencia intraempresarial no era objeto de estudio, cuanto menos de un estudio con carácter riguroso y sistemático, con pretensiones de alcance general. ${ }^{20}$ Entre los motivos de orden práctico, resalta la enorme dificultad -por no decir imposibilidad- de contabilizar con precisión la mal llamada delincuencia de cuello blanco (sobre la discusión terminológica y conceptual, vid. infra).

En los últimos años, la cuantificación económica del delito del trabajador en la economía de la empresa arroja unas cifras anuales cuyo impacto a escala nacional ha empezado a despertar preocupación, especialmente en las economías de Estados

\footnotetext{
17 SOLIVETTI, L.M., "La criminalità di impresa: alcuni commenti sul problema delle cause", Sociologia del Diritto No 1 (1987), p. 65.

${ }^{18}$ BUSSMANN, Causes of Economic Crime, cit. nota ${ }^{\circ} 14$, p. 10.

${ }^{19}$ Vid. FELSON, M., Crime and Everyday life, 2002 ( $\left.3^{\text {rd }} \mathrm{ed}\right)$.

${ }^{20}$ Así, en la actualidad comienzan a existir estudios empíricos con carácter continuado, siguiendo unos mismos parámetros y metodología. Vid., por ejemplo, "Economic crime: people, culture and controls", 4th biennial Global Economic Crime Survey, PricewaterhouseCoopers Investigations and Forensic Services \& Martin-Luther-University, 2007.
} 
Unidos y del Reino Unido. Sin embargo, a pesar del considerable interés que posee, en términos económicos, el análisis de la relación entre actividad económica y comportamiento delictivo -a fin de determinar las condiciones que favorecen su aparición-, la investigación sobre los delitos cometidos por los trabajadores en el seno de la empresa ha recibido escasa atención. El análisis global de costes debería reflejar las cifras que resultan tanto del "daño emergente" como del "lucro cesante", incluyendo también además de los daños directos derivados de la comisión de este tipo de delitos, aquellos "costes indirectos", como por ejemplo, los relativos a la monitorización de la actividad del trabajador $u$ otras medidas de control. El valor total resultante -con las limitaciones de los análisis que se han venido realizando- supone anualmente un impacto considerable para las economías norteamericana y británica. ${ }^{21}$

En Estados Unidos, la investigación llevada a cabo ya en 1989 por Dickens et al. reveló unas transferencias de la empresa a los trabajadores por medios delictivos por valor de $\$ 56$ billones. Más recientemente, en un estudio con datos del 2002, la Association of Certified Fraud Examiners (ACFE) atribuye el 87\% del valor de los delitos de los trabajadores a apropiaciones indebidas ('asset misappropriations'), con un coste medio de $\$ 80,000 .^{22}$ También en Estados Unidos, el estudio realizado por McGoey en 2005 atribuye la responsabilidad del 48\% de la disminución de los inventarios de los almacenes a hurtos de los trabajadores, con un coste directo de $\$ 15$ billones. ${ }^{23}$ Habría que añadir -en el sentido recientemente apuntado- el cálculo de costes indirectos derivados de la instalación de circuitos cerrados de videovigilancia $^{24}$ o el tiempo y otros medios empleados por el empresario en la resolución de los conflictos internos derivados. En Alemania -y desde Alemania- también se han realizado estudios en la materia, cuyos resultados arrojan de igual modo pérdidas económicas importantes. ${ }^{25}$ Los últimos datos disponibles, a partir de un estudio a nivel mundial, PricewaterhouseCoopers'2007 Global Economic Crime Survey, están basados en entrevistas llevadas a cabo en 5.400 empresas en 40 países distintos. Los datos globales establecen las siguientes pérdidas por empresa -teniendo en cuenta sólo los "costes directos"- $-:^{26}$

\footnotetext{
${ }^{21}$ RICKMAN/WITT, “The Determinants of Employee Crime”, cit nota n 11, p. 172.

${ }^{22}$ La ACFE delimita el concepto de "employee crime" en su estudio de 2002 definiéndolo como el deliberado uso desviado en beneficio propio por parte del trabajador de los bienes del empresario, citado en RICKMAN/WITT, "The Determinants of Employee Crime", cit. nota n 11, p. 161.

${ }^{23}$ Estudios citados en RICKMAN/WITT, "The Determinants of Employee Crime", cit. nota n 11, p. 161.

${ }^{24}$ Para un análisis del crecimiento de las cifras del sector de la video-vigilancia en los años noventa puede verse MCCAHILL, M., NORRIS, C., "Watching the workers: Crime, CCTV and the Workplace”, en: DAVIS, P., FRANCIS, P., JUPP, V., Invisible Crimes. Their Victims and their Regulation, London, 1999, p. 208.

25 Vid. referencias al último estudio de KPMG sobre delincuencia económica en Alemania en el FRANKFURTER Allgemeine ZeItUNG, "Wirtschaftskriminalität in Deutschland steigt", o en el SÜDDEUTSCHE ZEITUNG, "Wirtschaftskriminalität. Jede zweite Firma Opfer von Straftaten", ambos de 4 de julio de 2006. Vid. también, para conocimiento de cifras concretas, KPMG (1999) y PriceWaterhouse-Coopers (2003 y 2005); en el mismo sentido, el informe de Ernst \& Young (2003). Los estudios más recientes (por ejemplo, el informe de KPMG de 2006) siguen poniendo de relieve la tendencia al aumento.

${ }^{26}$ Cfr. "Economic crime: people, culture and controls", 2007, p. 8. En 2007, sobre un período de dos años, las empresas analizadas declararon unos costes indirectos (average management cost) de US\$ 550,356. La encuesta ofrece una visión en profundidad de las raíces y causas del delito económico (economic crime) y el modo en que éste incide a nivel mundial (con especial atención a los nuevos mercados emergentes).
} 
AGUSTINA, JOSÉ R. "Fenomenología del employee crime: Bases para definir Estrategias de prevención del delito intraempresarial".

"Average loss from fraud over two years per company in 2005:

US\$ $1,732,253$ Average loss from fraud over two years per company in 2007:

US\$ $2,420,700 ”$

En números absolutos, el importe total por pérdidas declarado por las empresas (total loss reported by respondents over two years) superó los US\$ 4.2 billion. El total estimado de pérdidas, incluyendo las pérdidas no detectadas de compañías con sistemas de control más débiles, se estableció en US\$ 5.7 billion. $^{27}$

Ante esta realidad, Davies y Jupp sostuvieron ya a finales de los noventa que las conexiones entre delito y trabajo habían sido sólo parcialmente examinadas en el ámbito de la Criminología. ${ }^{28}$ Una primera objeción que no se puede ocultar deriva de las dificultades inherentes a la difícil delimitación de la noción de lugar de trabajo (workplace), especialmente a partir de la revolución tecnológica, con la disociación entre lugar de trabajo y prestación laboral. Ciertamente, como han destacado algunos autores, es una tarea no exenta de problemas para el análisis, ${ }^{29}$ aunque ello no justifique la falta de la debida atención que se le ha dado al ámbito laboral como escenario delictivo.

Como señalan Rickman y Witt, las investigaciones sobre las relaciones existentes entre actividad económica y comportamiento criminal deberían centrarse en el abordaje de los factores determinantes o que pueden favorecer la comisión de delitos por parte de los trabajadores. ${ }^{30} \mathrm{Si}$ bien tratar de establecer tales factores determinantes de la delincuencia no permite reducir el comportamiento de los agentes implicados a variables econométricas, una aproximación al fenómeno delictivo desde la lógica económica y en el contexto empresarial puede aportar, más que en otros ámbitos, ciertas orientaciones esclarecedoras sobre las causas y la fenomenología delictiva. ${ }^{31}$

Reducir, interpretar o explicar las causas de la delincuencia en base a parámetros cuantificables siempre se topará con el problema de la libertad humana. Porque "imputar" significa "considerar un proceso como acción libre", tal y como afirmara

\footnotetext{
${ }^{27}$ Debe tenerse en cuenta que la unidad de medida "billion" equivale a mil millones.

${ }^{28}$ DAVIS, P., FRANCIS, P., JUPP, V., “Crime-Work Connections: Exploring the 'Invisibility' of Workplace Crime”, en DAVIS/FRANCIS/JUPP, Invisible Crimes, cit. nota ${ }^{\circ} 24$, pp. 55.

29 En ese sentido, existen muy diferentes formas de trabajo, así como muy variados contextos y escenarios en los que se puede desarrollar la actividad laboral. La dificultad en orden a unificar o estructurar un denominador común de lo que debe entenderse por lugar de trabajo ha quedado seriamente afectado por la irrupción de las nuevas tecnologías en la empresa y el tele-trabajo.

${ }^{30}$ RICKMAN/WITT, “The Determinants of Employee Crime”, cit. nota $n^{\circ} 11$, p. 172 . En este artículo analizan los resultados de un estudio empírico realizado, en el que se ha trabajado con un concepto extensivo de 'employee crime', abarcando el uso deliberado de los bienes del empresario en provecho personal del trabajador (ya se trate de hurtos de productos de la empresa, fraudes financieros o el uso no autorizado de equipos de la empresa para actividades no relacionadas con la prestación laboral): vid. p. 161.

31 La sociología del delito trata de establecer correlaciones causales. La psicología del delito, motivaciones personales. Ambas perspectivas pretenden explicar el fenómeno delictivo desde su perspectiva propia, pero ambas se topan en último término con la libertad humana como factor inexplicable. Lo que quiere señalarse es que, en el intento de hallar una explicación a por qué surge el delito, tal vez las variables econométricas y el cálculo económico tengan un mayor peso en el contexto de la empresa que, por ejemplo, en delitos sexuales o delitos contra la seguridad viaria. Mayor o menor peso no excluye que la posición económica del delincuente pueda tener cierta relevancia en el momento de realizar cualquier delito.
} 
Immanuel Kant: "imputamos [algo] si simpliciter es atribuido, esto es, cuando es concebido como procedente de la libertad". ${ }^{32}$ En ese sentido, tanto imputar como explicar las causas de un delito escapa a las leyes de la causalidad, razón por la cual puede ser objeto de reproche moral y jurídico.

Sin embargo, la racionalización y análisis de la inclinación por el delito en términos cuantificables y verificables presenta mayores facilidades en la criminalidad intraempresarial en tanto que (1) existe un mayor control y conocimiento en un ámbito reducido de la realidad social como es la empresa; (2) la inclinación al delito presenta una cierta similitud en función de la igualdad de posiciones y estándares de responsabilidad; y (3) el ámbito de la empresa permite un trabajo de verificación y falsación de hipótesis.

Desde este modo de análisis, Nick J. Dodd viene a identificar dos perfiles característicos del trabajador que comete un delito en la empresa, a partir del estudio de CCD (Corporate Crime Data Sample): el empleado problemático que genera problemas y aquél que no tienen nada que perder: “"Troublemaker' and 'Nothing to Lose' employee offenders". ${ }^{33}$ En este sentido, una importante fuente de información sobre el sujeto individual puede proceder del estudio de datos reales. Aunque algunos factores ya han sido objeto de investigación con cierta profundidad, tales como el género (Jones, 1972; Moretti, 1986; Terris, 1985), edad y estabilidad en el puesto de trabajo (Franklin, 1975; Hollinger and Clark, 1983; Hollinger et al., 1992; Robin, 1969; Robertson, 1993), presión económica (Dodd, 1998; Cressey, 1953), status (Greenberg, 1990Laird, 1950; Szwajkowski, 1989; Tucker, 1989), confianza (Cressey, 1953; Harrell and Hartnagel, 1976; Hollinger and Clark, 1983; Paul, 1982), integración o arraigo (Ditton, 1977; Hollinger, 1986; Hollinger and Clark, 1983; Mars, 1974; Murphy, 1993), rasgos de la personalidad (Murphy, 1993; Paajanen, 1988), no obstante, resulta difícil separar con nitidez y afirmar con determinación qué aspectos de tales factores que describen el perfil criminológico del trabajador proceden de los resultados de la investigación empírica disponible. Concretamente, la validez y fiabilidad de los rasgos de la personalidad ha sido puesta en entredicho debido a su falta de consistencia en el tiempo y el carácter temporal de ciertas actividades desviadas (Sackett, 1985; Sackett and Harris, 1985). ${ }^{34}$

Así, siguiendo un nuevo modo de aproximarse a la realidad del delito mediante un enfoque económico, introducido por primera vez por Becker (1968), ${ }^{35}$ los economistas se comenzaron a interesar por el estudio del comportamiento criminal, pero sin prestar demasiada atención en un primer momento a los delitos de los

\footnotetext{
${ }^{32}$ HRUSCHKA, J., Prohibición de regreso y concepto de inducción. Consecuencias, ("Regreßverbot, Anstiftungsbegriff und die Konsequenzen”, en ZStW 110 [1998], pp 581-610), trad. Pablo SÁNCHEZOSTIZ, en Revista de Derecho Penal y Criminología $N^{\circ} 5$ (2000), pp. 189-218 (en donde se cita KANT, I., AA, vol. XIX, p 157, 1. 20 y ss., refl. 6775).

${ }^{33}$ Cfr. al respecto, DODD N.J., "“'Troublemaker' and 'Nothing to Lose' Employee Offenders Identified from a Corporate Crime Data Sample”, Crime Prevention and Community Safety: An International Journal 2004, 6 (3), 23-32; vid. también, el estudio llevado a cabo por SPEED, M., "Reducing Employee Dishonesty: In Search of the Right Strategy in Managing Security", Crime at Work (Volume III), Leicester, 2003, Chapter 10, pp. 157-179.

${ }^{34}$ DODD, Ibid., 2004, pp. 24-25. Una de sus tesis consiste en que no se puede distinguir al trabajador que delinque del resto de sus compañeros de trabajo que no muestran comportamientos desviados.

${ }^{35}$ BECKER, G., "Crime and punishment: an economic approach", Journal of Political Economy $\mathrm{N}^{\circ} 76$ (1968), pp. 169-267.
} 
AGUSTINA, JOSÉ R. “Fenomenología del employee crime: Bases para definir Estrategias de prevención del delito intraempresarial".

trabajadores (employee crime). ${ }^{36}$ Posteriormente, Barnes y Lambell (2002) realizaron por vez primera un estudio en el ámbito de la criminalidad en la empresa, en el que se introducía la metodología propia de la Econometría. ${ }^{37}$ Sin embargo, su trabajo se fundamentó exclusivamente en las percepciones procedentes de las organizaciones empresariales, restando por tanto fiabilidad a las conclusiones obtenidas. No es hasta la reciente investigación llevada a cabo por Rickman y Witt (2005), cuando se empieza a trabajar empleando datos procedentes de los delitos registrados en el seno de las empresas -en su estudio, limitado al Reino Unido-. Su trabajo de campo aporta una información extraída directamente de la realidad, abarcando datos sobre los hurtos cometidos por los trabajadores, las políticas que pueden ayudar a combatirlos y los puntos de vista alternativos sobre las distintas motivaciones para cometer el delito. ${ }^{38}$ Finalmente, Bussman y Werle (2006) dan un paso más y realizan el primer estudio del delito en la empresa de carácter transnacional.

La investigación de Bussman y Werle se lleva a cabo mediante una encuesta global a más de 5.500 empresas, combinando información sobre las propias compañías, su victimización y sobre el descubrimiento y resolución de 2.900 incidentes relativos a este tipo de delitos. ${ }^{39}$ La relevancia del estudio se debe en gran medida al ámbito mundial de la encuesta y al volumen de la muestra de datos en los que se basa, revelando como resultado ciertos rasgos comunes en la perpetración y victimización del delito en la empresa, así como ciertas pautas homogéneas también en los modus operandi registrados.

Desde una perspectiva más reducida en cuanto al objeto de análisis, en el ámbito español, Landwell \& Pricewaterhouse Coopers ha presentado un informe bajo el título "Actos desleales de trabajadores usando sistemas informáticos e Internet". 40 Entre las conclusiones, se presenta - de forma similar a los Corporate Crime Data (CCD) $-^{41}$ un cuadro con las infracciones más habituales, acompañado de una descripción de algunos elementos más comunes relativos a la génesis $\mathrm{y}$ fenomenología del employee crime, tales como el modus operandi, las motivaciones del trabajador o las situaciones que han facilitado la comisión del delito o infracción.

\footnotetext{
${ }^{36}$ DICKENS, W.T., KATZ, L.F., LANG, K., SUMMERS, L.H., "Employee crime and the monitoring puzzle”, Journal of Labour Economics N 7 (1989), pp. 331-347.

${ }^{37}$ BARNES, P., LAMBELL, J., "Organisational Susceptability to Fraud: Does Fraud Strike Randomly or Are There Organisational Factors Affecting its Likelihood and Size?", Working Paper, Nottingham Business School, (2002).

${ }^{38}$ RICKMAN/WITT, “The Determinants of Employee Crime” cit. nota n 11, p. 161.

${ }^{39}$ BUSSMANN, K.-D., WERLE, M. M., "Addressing Crime in Companies. First Findings from a Global Survey of Economic Crime”, British Journal of Criminology N 46 (2006), pp. 1128-1144.

${ }^{40}$ De forma similar a los CCD, la finalidad principal del estudio es obtener conclusiones sobre los tipos de infracciones que se cometen con más frecuencia, la estrategia seguida por las empresas, el porcentaje de casos a los que se llega a un acuerdo, los sectores más afectados, las motivaciones que hacen que los trabajadores actúen de esta manera, la cuantía de los daños y la evolución cronológica de las infracciones. El estudio se realizó a partir del análisis de 393 casos en empresas españolas, desde el 1 de enero de 2001 hasta el 31 de diciembre de 2003 (vid. "Actos desleales de trabajadores usando sistemas informáticos e internet", Informe elaborado por Landwell-PwC, dirigido por Javier Ribas, responsable del Departamento de Derecho de las Tecnologías de la Información, Relaciones Laborales, $\mathrm{N}^{\circ}$ 21, Año XX, Quincena del 8 al 23 Nov. 2004, p. 1317, Tomo 2, Editorial La Ley (LA LEY 2355/2004).

${ }^{41}$ RICKMAN/WITT, “The Determinants of Employee Crime”, cit. nota n 11, p. 172, donde cita los estudios de BARNES y LAMBELL: vid. BARNES/LAMBELL, "Organisational Susceptability to Fraud", cit. nota ${ }^{\circ} 37$.
} 
Al tratarse de un listado de infracciones, no recoge conductas delictivas en sentido estricto, aunque en la práctica la línea divisoria entre delito, infracción $e$ irregularidad presenta contornos difusos: ${ }^{42}$

\subsection{Creación de una empresa paralela, utilizando activos inmateriales de la empresa.}

Consiste en la explotación en una empresa de nueva creación, de la propiedad intelectual, la propiedad industrial o el know how de la anterior empresa. Generalmente, el trabajador constituye la nueva compañía antes de solicitar la baja voluntaria y realiza un proceso de trasvase de información mediante soportes informáticos o a través de Internet. Es posible que el trabajador actúe de forma conjunta con otros compañeros de la empresa. Los hechos pueden tener relevancia penal a la luz del artículo 278 del Código Penal Español (en adelante, CPE) que tipifica el delito de descubrimiento y revelación de secretos de empresa.

\subsection{Daños informáticos y uso abusivo de recursos informáticos}

Los daños informáticos se producen generalmente como respuesta a un conflicto laboral o a un despido que el trabajador considera injusto. Consisten en la destrucción, alteración o inutilización de los datos, programas o cualquier otro activo inmaterial albergado en redes, soportes o sistemas informáticos de la empresa. Los casos más habituales reflejados en el informe son los virus informáticos, el sabotaje y las bombas lógicas, programadas para que tengan efecto unos meses después de la baja del trabajador. También es habitual el uso abusivo de recursos informáticos, especialmente el acceso a Internet. ${ }^{43}$ Los hechos pueden realizar el tipo penal del artículo $264 \mathrm{CPE}$ (delito de daños).

\subsection{Información confidencial y datos personales}

Consiste en el acceso no autorizado y posterior revelación a terceros, generalmente competidores o clientes, de información confidencial de la empresa. En algunas ocasiones, la revelación la realizan trabajadores que tienen un acceso legítimo a la información pero sobre los que pesa una obligación de reserva. En este capítulo también se contempla la cesión no autorizada a terceros de datos personales de trabajadores y clientes. Los hechos pueden tener relevancia penal a la luz del artículo 197, 199 y 278 CPE (descubrimiento y revelación de secretos de personas físicas o de valor empresarial), dependiendo del bien jurídico lesionado, en función de que la información afecte a la intimidad personal o a un secreto de empresa, y de si se el acceso a la información deriva del hecho de ser el responsable del fichero o de cualquier otra fuente de información.

\subsection{Amenazas, injurias y calumnias}

El medio utilizado habitualmente es el correo electrónico corporativo, aunque también se han utilizado cuentas anónimas, e incluso se ha suplantado la identidad de otro

\footnotetext{
${ }^{42}$ BLOUNT, Occupational Crime, cit. nota $\mathrm{n}^{\circ} 2$, p. 4, donde se refiere a un concepto multidimensional de "occupational crime" como comportamiento abusivo del trabajador para abarcar el problema en toda su naturaleza.

${ }^{43}$ Aunque el uso abusivo no es prima facie un comportamiento delictivo, vid. SNIDER, L., "Crimes against capital: Discovering theft of time”, Social Justice, Vol. 28, N³ (2001), pp. 105-120.
} 
AGUSTINA, JOSÉ R. “Fenomenología del employee crime: Bases para definir Estrategias de prevención del delito intraempresarial".

trabajador de la misma empresa. En el caso de las amenazas, se busca un beneficio material o inmaterial para el trabajador. Si el beneficio no se produce, el trabajador llevará a cabo la conducta anunciada en el mensaje amenazador. En el caso de las injurias y las calumnias, se busca desacreditar a la empresa, o a alguno de sus directivos. También se han producido insultos a clientes habituales o a clientes potenciales de la empresa con los que el trabajador tenía algún conflicto. ${ }^{44}$

El informe señala tres clases más de infracciones habituales: infracciones relativas a la propiedad intelectual e introducción de obras de la empresa en redes P2P; intercambios de obras de terceros a través de redes P2P; e infracciones relativas a derechos de propiedad industrial.

\section{Una aproximación antropológica al delito en el lugar de trabajo}

En términos descriptivo-generales, la mayoría de los delitos que tienen lugar en un entorno laboral son delitos normales, cometidos por personas normales, en las circunstancias normales de su lugar de trabajo. ${ }^{45}$ Es decir, son delitos de personas socialmente adaptadas ante ocasiones delictivas ordinarias.

Así pues, las personas normales están inclinadas a cometer delitos en circunstancias normales que representen una ocasión propicia. A partir de las tesis criminológicas de la "teoría de la actividad rutinaria" ("routine activities theory"), ${ }^{46}$ se comenzó a tratar de explicar el comportamiento delictivo como una función procedente de las características de la situación de la que emana el delito. Tales situaciones generan una oportunidad para que aquellas personas inclinadas a delinquir puedan beneficiarse mediante una acción ilegal. Según la "teoría de la actividad rutinaria", función, situación y oportunidad son, en este sentido, realidades interconectadas (vid. infra, al tratar sobre las distintas estrategias de prevención situacional).

Conviene anticipar que el núcleo de la aproximación teórica al delito de la "routine activities theory" consiste en que un delito se llevará a cabo cuando se encuentren tres elementos: (1) una específica situación (coordenadas de espacio y tiempo); (2) un objetivo (a target); y (3) la ausencia de vigilancia efectiva. La concurrencia de estas tres circunstancias ofrece al delincuente la oportunidad para cometer satisfactoriamente un hecho criminal. ${ }^{47}$

La base antropológica del pensamiento de Marcus Felson parte de una visión del ser humano que resalta su debilidad moral en el obrar (basic human frailty). El individuo, considerando esa fragilidad connatural, necesita la ayuda de la sociedad para refrenar las tentaciones inmorales y superar la presión negativa. El problema práctico estriba en cómo ayudar a la persona a dominar sus debilidades mediante una estructuración

\footnotetext{
${ }^{44}$ Las amenazas están tipificadas como delito en el artículo 169 y siguientes del CPE, las injurias en el artículo 205 y siguientes del CPE, y las calumnias están tipificadas como delito en el artículo 208 y siguientes del CPE.

${ }^{45}$ MARS G., Cheats at Work, 1982, p. 1. A este tipo de delincuencia ordinaria la denominó Ditton "part-time crime": vid. DITTON, J., Part-Time Crime: an Ethnography of Fiddling and Pilferage, London, 1977.

${ }^{46}$ COHEN, L.E., FELSON, M., "Social change and crime rate tends: a routine activities approach", American Sociological Review $\mathrm{N}^{\circ} 44$ (1979), pp. 588-608.

${ }^{47}$ MCLAUGHLIN/MUNCIE, The Sage Dictionary of Criminology, cit. nota ${ }^{\circ}$ 5, pp. 278-279.
} 
de la sociedad, reduciendo las tentaciones delictivas. Desde tal concepción, buena parte del comportamiento humano tiene un componente situacional: el comportamiento de la persona depende en parte de quién está presente, dónde y cuándo. ${ }^{48}$ En estas coordenadas existenciales, la prevención situacional no se considera una técnica de conducción determinista del obrar humano ni, necesariamente, responde a una concepción pesimista respecto del hombre. El realismo práctico de la teoría de Marcus Felson radica, sin más, en centrarse en aquellos mecanismos presentes en la vida ordinaria de las personas. Reducir las oportunidades delictivas significa restringir la libertad-para-el-delito, acotar el campo de posibilidades en el obrar desviado.

En base a esta teoría criminológica, el contexto laboral es susceptible, en ese sentido, de albergar situaciones y oportunidades que favorezcan la comisión de delitos por parte de los trabajadores. Para detectar tales situaciones y prevenir la generación de ocasiones, se requiere comprender las raíces de la conducta delictiva en el lugar de trabajo, a fin de establecer las estrategias preventivas adecuadas. Conviene, por tanto, investigar los patrones delictivos del employee crime: la relación existente entre los diferentes puestos de trabajo o tipos de trabajo y la correlativa inclinación a la delincuencia o tipos de delitos asociados a los mismos.

La referida normalidad del delito intraempresarial, no obstante, no es incompatible con la existencia de personas con perfiles psicopáticos en el entorno de la empresa. El fenómeno ha sido descrito por Robert D. Hare, quien introdujo las herramientas de diagnóstico de tales transtornos de la personalidad denominadas Psychopathy Checklist. Así, mediante instrumentos de análisis estandarizados pretende discernir cuándo y por qué hombres con educación, embutidos en carísimos trajes, cometen delitos de cuello blanco conducidos por una personalidad psicopática. ${ }^{49}$

Con todo, el conocimiento de la interacción entre la persona y su entorno laboral, en la medida en que puede obedecer a patrones de conducta generalizables generalmente no psicopatológicos-, aporta una perspectiva antropológica del delito en el lugar de trabajo. Desde una tal perspectiva antropológica, Gerald Mars realiza una aproximación a la criminalidad de las personas en su entorno laboral, tratando de establecer relaciones entre tipos de trabajo y tipos de delitos. ${ }^{50}$

En su modo de abordar una explicación del delito en el lugar de trabajo, Mars se inspira en la perspectiva general adoptada por Henry para explicar cómo funciona la sociedad. Su punto de partida radica en que no se puede comprender el modo de operar de la sociedad a menos que consideremos la vertiente informal de nuestras instituciones sociales. ${ }^{51}$ Así, en el contexto laboral se descubre todo un sistema de "recompensas informales", al margen de los canales formales de retribución de los trabajadores.

\footnotetext{
${ }^{48}$ Vid. FELSON, M., Crime and Everyday life, 1994, p. 16-19.

${ }^{49}$ Vid. HARE, R.D., Sin conciencia, 2003 (título original Without Conscience, 1993), pp. 137-162.

${ }^{50}$ En sus investigaciones se aprecia la novedad de intentar construir una antropología de los delitos en el lugar de trabajo, tratando de relacionar persona y entorno en el ámbito laboral: vid. MARS G., Cheats at Work, 1982.

${ }^{51}$ MARS, Cheats at Work, cit. nota ${ }^{\circ} 50$, p. 7, donde cita la obra de Henry: HENRY, S., Can I Have It In Cash? A Study Of Informal Institutions and Unorthodox Ways of Doing Things, London, 1981, p. 1 .
} 
AGUSTINA, JOSÉ R. "Fenomenología del employee crime: Bases para definir Estrategias de prevención del delito intraempresarial".

Consciente de la necesidad de conocer cómo operan esas "instituciones sociales informales" para llegar a comprender el funcionamiento global del sistema, Mars aplica esa misma lógica explicativa al funcionamiento de las personas en su entorno laboral. Mutatis mutandis, el rasgo central que caracteriza los puestos de trabajo desde tal punto de vista consiste en el modo en que las recompensas se distribuyen dentro de la empresa, particularmente en la naturaleza y fuente de esas recompensas informales que se dan normalmente en todo puesto de trabajo. ${ }^{52}$ Tal es la realidad fáctica en la empresa que describe Mars, una dualidad de sumandos que contempla el trabajador, y por la que se derivan compensaciones, ventajas y recompensas, ya sea en el limbo de la legalidad, adentrándose levemente en el ámbito de la antijuricidad en un sentido amplio, o ya más concretamente en el terreno propio de la tipicidad penal.

Un tal enfoque descriptivo, de carácter fáctico, al margen de la realidad normativa, de los libros de contabilidad o de los estándares socio-laborales, puede aplicarse también -aunque no se haga mención en la obra de Gerald Mars- a la actividad del empresario y, concretamente, al ejercicio de su poder de control sobre los trabajadores. En el reverso de la relación laboral, el empresario puede emplear en ocasiones mecanismos y formas de control al margen de la legalidad. Se llega entonces a utilizar un doble lenguaje: por un lado, se adoptan medidas de carácter laboral en la superficie visible de las relaciones de trabajo, y por otro, se opera de forma clandestina, al margen de la legalidad, realizando de forma subrepticia un control más incisivo, que no podría llevarse a cabo de otra forma, y que a la postre suministra una información de mayor valor para el empresario. Aunque las leyes laborales o penales impidan, por ejemplo, aportar en sede jurisdiccional pruebas obtenidas de forma oculta o ilícita que conculquen la dignidad del trabajador, ello no obsta para que se practiquen en la realidad determinadas formas ilícitas de control, permaneciendo en el ámbito de ese limbo jurídico. Al estar prohibidas esas prácticas nunca aflorarán a la superficie, pero se utilizarán por otras vías, una vez obtenido ese conocimiento.

Así, si mediante el control clandestino del correo electrónico de los trabajadores, o mediante la instalación de cámaras ocultas, se advierten determinados hurtos, ausencias prolongadas del puesto de trabajo, pérdidas de tiempo, ciertas opiniones en materia personal o laboral con incidencia en la afinidad personal con sus superiores por mencionar algunos ejemplos-, el empresario estará en condiciones de adoptar medidas de protección del patrimonio empresarial, podrá modificar su plan inicial de promoción del personal de plantilla, reasignará las funciones encomendadas sustrayéndolas de la esfera de dominio de trabajadores desleales-, o buscará con ahínco cualquier otro motivo justificado para un efectuar un despido procedente o, si el riesgo de daño detectado fuera importante, improcedente. ${ }^{53}$

\footnotetext{
${ }^{52}$ MARS, Cheats at Work, cit. nota $\mathrm{n}^{\circ} 50$, p. 7.

${ }^{53}$ Piénsese, por ejemplo, que en algunos casos en que el empresario descubre ilícitamente la deslealtad a la empresa de un trabajador, tras un cálculo de consecuencias, puede acabar decidiendo no renovarle el contrato sin motivo aparente. Una posible estrategia empresarial puede encaminarse a evitar a toda costa cualquier conflicto laboral aun teniendo posibles alternativas lícitas de acción -especialmente con trabajadores problemáticos-, buscando modos pacíficos de finalizar la relación laboral, a pesar de que aparentemente el coste de la medida sea menos beneficioso -por ejemplo, si en lugar de despedirlo, decide esperar al término natural del contrato para evitar represalias--
} 
Mars parte así de la observación del entorno laboral. El fuerte arraigo en el mundo de la empresa de una realidad informal explica y mantiene en funcionamiento el propio sistema. En muchos puestos de trabajo existen pequeñas trampas, recompensas paralelas, ventajas adicionales, comúnmente aceptadas por los trabajadores, que entretejen la vida diaria del entorno laboral. Existen tareas u oficios, carreras profesionales en su completitud, y hasta organizaciones enteras, que no podrían llevarse a cabo sin este tipo de recompensas ilícitas. De éstas depende todo el sistema salarial, en la medida en que las tiene en cuenta. Las pequeñas trampas penetran la cultura del mundo del trabajo, generando unas reglas de comportamiento específicas. Esta realidad fáctica existe y merece un examen detenido. El problema radica en dónde y cómo establecer los límites que separan una pequeña trampa de un hecho delictivo significativamente relevante. ${ }^{54}$

\section{Perfiles laborales, perfiles criminológicos}

En orden a establecer una clasificación de tipos de trabajos e inclinación al delito, ${ }^{55}$ Mars propone adoptar como patrón de análisis la perspectiva antropológica utilizada por Mary Douglas en su estudio sobre las sociedades no industrializadas. ${ }^{56}$ Ciertamente, la tarea de comparar y erigir reglas comunes, ya sea entre culturas o entre puestos de trabajo, requiere de un tertium comparationis. Clasificar requiere la búsqueda previa de tales elementos estructurales que vertebran y permiten la comparación. El objetivo que Douglas se propone es llegar a establecer una base para poder comparar las distintas culturas que han sido objeto de investigación por los antropólogos. Su punto de partida se fundamenta en el postulado según el cual todas las culturas pueden valorarse y clasificarse de acuerdo con dos dimensiones (individual y grupal). ${ }^{57}$

La primera dimensión la denomina 'grid dimension', refiriéndose al modo en que todas las culturas imponen unas determinadas categorías sociales sobre el conjunto de la población, estableciendo el comportamiento adecuado del individuo, así como el comportamiento del resto de ciudadanos hacia el individuo. Tal categoría social definida por la sociedad encerraría al sujeto conforme a la categoría social a la que pertenece -'grid' podría traducirse como cuadrícula o reja-. Aunque con una terminología distinta a Niklas LuhmanN, se está describiendo el modo de creación de expectativas sociales en base a roles, es decir, aquellas funciones específicas impuestas por la sociedad mediante la asignación y distribución de responsabilidades en un contexto determinado. La reducción de la complejidad de las interacciones humanas y la orientación de expectativas se facilita por medio de la asignación de tales etiquetas o indicadores externos a distintas posiciones sociales -ya sean tipos de profesión o puestos de trabajo-.

\footnotetext{
${ }_{55}^{54}$ MARS, Cheats at Work, cit. nota ${ }^{\circ} 50$, pp. 17-20.

${ }^{55}$ MARS emplea indistintamente a lo largo de su trabajo expresiones informales como 'cheats', 'fiddles', 'perks', que podrían traducirse por trampas o ventajas adicionales, aunque ello no obsta a que entre tales puedan incluirse auténticos delitos.

${ }^{56}$ MARS, Cheats at Work, cit. nota $\mathrm{n}^{\circ} 50$, p. 24, donde cita las obras de Douglas en que se menciona su teoría: vid. DOUGLAS, M., Natural Symbols, London, 1970; DOUGLAS, M., Cultural Bias, London, 1978; y, finalmente, DOUGLAS, M., ISHERWOOD, B., The World of Goods: Towards an Anthropology of Compsumption, Harmondsworth, 1978.

${ }^{57}$ Mars, basándose en el trabajo de Douglas, establece que "all cultures can be assessed and classified according to two dimensions -the first she calls grid and the second group" (vid. MARS, Cheats at Work, cit. nota $\mathrm{n}^{\circ} 50$, p. 24).
} 
AGUSTINA, JOSÉ R. “Fenomenología del employee crime: Bases para definir Estrategias de prevención del delito intraempresarial".

Así por ejemplo, desde una perspectiva sociológica general, el sistema de castas en la India se basa en un modo de distribución de roles especialmente fuerte e intenso -la vertebración social es, en este sentido, especialmente rígida en base a la marcada configuración de roles individuales-. En el plano ya más específico de las ocupaciones en el lugar de trabajo, Mars señala que en orden a valorar la fortaleza de la creación de expectativas en base a roles (grid dimension) se deben tener en consideración cuatro elementos: (1) autonomía, es decir, el grado de constreñimiento que las reglas ejercen sobre el tipo de trabajo -por ejemplo, en el caso de un guardia de seguridad el nivel de autonomía es realmente bajo-; (2) aislamiento respecto del resto de miembros del grupo: en la medida en que se estructuran y diferencian las personas en base a categorías profesionales, se establecen separaciones entre los individuos y se predeterminan sus funciones, el tipo de respuesta que se espera de cada uno, etc., estableciéndose un sistema de mayor rigidez estructural; (3) grado de reciprocidad, en el sentido de que la flexibilidad o rigidez de un puesto de trabajo guarda cierta proporción respecto del grado de dependencia mutua entre los puestos de trabajo relacionados -así, el jefe ostenta gran discrecionalidad para ofrecer flexibilidad a las personas que dependen de su trabajo, como su secretaria, sin que ésta posea recíprocamente esa capacidad-; (4) competencia, es decir, a mayor aislamiento generalmente corresponde menor competitividad. ${ }^{58}$

La segunda dimensión se construye en función del grado de influencia del grupo (group dimension). La cultura dominante puede minimizar o maximizar el control sobre los individuos por parte del grupo, fortaleciendo o debilitando los vínculos. La importancia preponderante del grupo sobre el individuo puede ser mayor o menor en función del tipo de sociedad.

Desde una perspectiva criminológica más general, la "teoría de la asociación diferencial" (differential association) puso de relieve el influjo que ejerce el contacto con determinados entornos y la asociación en determinados grupos sociales en la adquisición y mantenimiento de comportamientos delictivos. ${ }^{59} \mathrm{La}$ teoría explicativa articulada por Sutherland ofrece una visión integrada de la criminalidad desde la psicología y la sociología del delito, ${ }^{60}$ especialmente aplicable a la delincuencia en el seno de la empresa. ${ }^{61}$ Así, los postulados básicos de la teoría de la asociación diferencial son especialmente aplicables a algunas formas de criminalidad relativas al lugar de trabajo: (1) el comportamiento delictivo es objeto de aprendizaje: requiere una formación, no es una realidad genéticamente heredada (criminal behavior is learned); (2) tal aprendizaje tiene lugar a través del contacto o asociación con otros individuos (criminal behavior is learned in interaction with other persons in a process of communication); (3) el lugar principal donde se adquiere ese aprendizaje es en el interior de grupos personales de carácter reducido -por contraposición al influjo que puede ejercerse desde los medios de comunicación u otras altas instancias despersonalizadas-; (4) el aprendizaje incluye tanto el modo externo del delito, esto

\footnotetext{
${ }^{58}$ MARS, Cheats at Work, cit. nota ${ }^{\circ} 50$, pp. 25-26.

${ }^{59}$ SUTHERLAND, Principles of Criminology, cit. nota ${ }^{\circ} 7$, pp. 5-9, donde expone el proceso a través del cual una persona se llega a involucrar en conductas delictivas (genetic explanation of criminal behavior).

${ }^{60}$ MCLAUGHLIN/MUNCIE, The Sage Dictionary of Criminology, cit. nota ${ }^{\circ}$ 5, p. 130.

${ }^{61}$ Vid. al respecto, PIQUERO, N.L., TIBBETTS, S.G., BLAKENSHIP, M.B., "Examining the role of differential association and techniques of neutralization in explaining corporate crime", Deviant Behavior $\mathrm{N}^{\circ} 26$ (2005), pp. 159-158.
} 
es, las técnicas comisivas y modus operandi, como la actitud interna, motivación, impulso y racionalización que sustenta la conducta delictiva; (5) una persona se inclina por el delito (becomes delinquent) cuando a su alrededor el nivel de definiciones favorables a infringir la legalidad es superior a las definiciones no favorables en sentido contrario; ${ }^{62}(6)$ las asociaciones diferenciales pueden variar en función del grado de influencia en base a factores como la frecuencia, duración, prioridad e intensidad; (7) el proceso de aprendizaje de la conducta delictiva no se diferencia del aprendizaje de cualquier otro tipo de comportamiento -la seducción por el delito no se limita a un proceso de imitación-.

En cuanto a valorar el grado de encorsetamiento que implica la pertenencia al grupo, Mars propone también tener en consideración cuatro elementos: (1) el nivel de frecuencia en el número e intensidad de interacciones con otros trabajadores, ya sea compartiendo el mismo trabajo o en tareas relacionadas; sin embargo, la frecuencia de contactos en sí misma no implica una intensa influencia del grupo -así, una dependienta interacciona constantemente con clientes sin que se constituya por ese hecho grupo alguno-; (2) el carácter mutuo en un grupo de trabajo interconectado; (3) la fortaleza del grupo se incrementa en función de la expansión del ámbito o tipo de actividades que abarca la vida social del grupo -así, un grupo de trabajo que comparte la misma residencia proporcionada por la empresa-; un último elemento fácilmente apreciable en grupos de fuerte vinculación es (4) la presencia de unos contornos bien definidos. Sin embargo, la precisión de los contornos de pertenencia al grupo pueden pasar desapercibidos, o por el contrario mostrarse de forma externa, creando una mayor conciencia de identidad compartida.

En función de las variables utilizadas por Mars, relativas a las características del tipo de trabajo (grid dimension) y la integración en el grupo (group dimension), describe cuatro tipos de perfiles criminológicos en el lugar de trabajo. Su proclividad delictiva deriva de los rasgos que caracterizan a los siguientes tipos de trabajadores:

(1) Contornos difusos a nivel individual y vínculos débiles a nivel grupal (weak-grid and weak-group). En primer lugar describe a aquellas personas que ocupan puestos de trabajo caracterizados por una gran autonomía organizativa, con tendencia al individualismo en el modo de funcionar y un nivel alto de competitividad por el tipo de trabajo que llevan a cabo. El control que ejercen sobre otras personas es muy superior al que se lleva a cabo sobre este tipo de profesionales. En este tipo de puestos de trabajo, es especialmente valorada la iniciativa personal y el espíritu emprendedor, la discrecionalidad para negociar con autonomía. En un primer momento, Mars sitúa en este grupo de trabajadores (a los que denomina 'Hawks') a directivos de empresa, académicos que han alcanzado un cierto nivel de éxito profesional y a pequeños empresarios que han creado su propia empresa. Sin embargo, el perfil profesional que caracteriza a este tipo de profesionales no se limita a las categorías sociales de más

\footnotetext{
${ }^{62}$ De aquí procede el principio de la asociación diferencial: se refiere tanto a las asociaciones delictivas como aquellas contrarias al delito, y a su contraposición de fuerzas. La persona actúa como un delincuente al entrar en contacto con patrones de conducta delictivos y, en sentido inverso, al aislarse de patrones de conducta contrarios al delito. La tesis principal es que cualquier persona asimila inevitablemente las pautas culturales que le rodean a menos que otros modelos de conducta alternativos entren en conflicto, con independencia de que muchas de las experiencias recibidas por la cultura circundante poseen un carácter neutral -similar al aprendizaje del niño respecto a cepillarse los dientes-(vid. SUTHERLAND, Principles of Criminology, cit. nota $\mathrm{n}^{\circ}$ 7, p. 6).
} 
AGUSTINA, JOSÉ R. "Fenomenología del employee crime: Bases para definir Estrategias de prevención del delito intraempresarial".

alto nivel: en cierto modo, también entrarían aquel taxista que es propietario del automóvil que emplea para su trabajo, o el camarero que goza de cierta autonomía y experiencia. El carácter competitivo como rasgo dominante en esta clase de profesionales, junto a los débiles vínculos que se generan entre sus iguales, conlleva que las alianzas entre 'hawks' tiendan a cambiar con relativa frecuencia y que el clima que se respire entre los miembros del grupo esté dominado por la sospecha más que por la confianza mutua. ${ }^{63}$

De este modo, el carácter independiente, la tendencia dinámica a la búsqueda de nuevas oportunidades, la capacidad de adaptación, todas las características presentes en tales perfiles laborales inducen a este tipo de profesionales a abrirse su propio camino y a aprovechar las ventajas y la flexibilidad que define su puesto de trabajo. En parte, esta forma flexible de convivencia junto con las ventajas adicionales a una autonomía y ausencia de controles pueden explicar cómo y por qué funciona el sistema. ${ }^{64}$ Los 'hawks' están a menudo protegidos frente a cualquier forma de control, por razón de su status y de su statelessness -condición de apátrida, en cuanto a la ausencia de vínculos respecto de cualquier grupo- ${ }^{65}$ Mars describe algunas situaciones en las que un profesional de estas características puede ver peligrar su posición: cuando su jefe inmediato deja el cargo y tiene que renegociar de nuevo sus condiciones contractuales; cuando organizaciones que deberían basarse en el instinto emprendedor se ven aplastadas por una burocracia paralizante; o cuando un directivo es rebajado de nivel y se le retira de un cargo. En tales situaciones los 'hawks' no pueden explotar sus mejores cualidades y se ven capitidisminuidos. Sin embargo, saben sobreponerse y sortear los obstáculos que limitan su potencial, reafirmándose en otros campos en los que sí pueden gozar de libertad de movimientos. ${ }^{66}$

El tipo de trampas (fiddles) a las que recurren los 'hawks' son parte de la propia elasticidad que configura el tipo de puestos de trabajo. En este sentido, las inclinaciones a aprovecharse de las circunstancias mediante recompensas ilícitas son intrínsecas al tipo de trabajo, y no extrínsecas. Si a un 'donkey' (vid. al respecto, infra) le remueves las condiciones que le permiten aprovecharse del sistema y crearse ventajas paralelas o recompensas, no alterará su forma de trabajar: no suele ocurrir así cuando le quitas a un 'hawk' las recompensas paralelas en su trabajo. ${ }^{67}$

(2) Contornos bien delimitados a nivel individual y vínculos débiles a nivel grupal (strong-grid and weak-group). En segundo lugar, describe a aquellas personas que ocupan puestos caracterizados por el aislamiento y la subordinación ('donkeys'). El ejemplo paradigmático de este tipo de profesiones o puestos de trabajo son los 'skivvies', aquellos sirvientes personales en el ámbito familiar, que era común tener

\footnotetext{
${ }^{63}$ MARS, Cheats at Work, cit. nota ${ }^{\circ} 50$, p. 29.

${ }^{64}$ Estos factores pueden explicar por qué, por ejemplo, algunos cirujanos de prestigio permanecen en el Nacional Health Service, donde los salarios son formalmente más bajos, o algunos cerebros tecnológicos no siempre se van al extranjero: vid. MARS, Cheats at Work, cit. nota ${ }^{\circ} 50, \mathrm{pp} .42$ y ss.

${ }^{65}$ MARS, Cheats at Work, cit. nota ${ }^{\circ} 50$, p. 54.

${ }^{66}$ En el contexto de tal cambio de circunstancias, menciona dos casos prototípicos de la flexibilidad y adaptabilidad del 'hawk': la tendencia al pluriempleo (moonlighters) y las tensiones entre el control y el fomento de la creatividad de los trabajadores para evitar que se vayan a la competencia (breakaways): vid. MARS, Cheats at Work, cit. nota ${ }^{\circ} 50$, pp. 61 y ss.

${ }^{67}$ MARS, Cheats at Work, cit. nota ${ }^{\circ}$ 50, p. 65. Así, si se implementan mecanismos para prevenir que una dependienta de un supermercado no cometa pequeñas sustracciones de la caja registradora, esa medida no alterará la forma de trabajar de este tipo de trabajadores.
} 
en los hogares en el siglo XIX (Douglas, 1978). Los 'donkeys' se hallan en una paradójica posición entre una extrema fragilidad y un enorme poder. Pueden llegar a gozar de enorme poder en el sentido de que cuando se les rechaza - o no se les acoge debidamente- los efectos que pueden llegar a provocar podrían suponer un trastorno importante. Es relativamente frecuente que este tipo de trabajos generen resentimiento. Y por tanto, no es inusual que haya un alto nivel de rotación en tales oficios o que el trabajador busque otras alternativas para escapar de la desagradable realidad laboral en que convive mediante el recurso al absentismo o la enfermedad. También pueden darse diferentes formas de sabotaje, especialmente cuando los límites y controles son de naturaleza mecánica (Taylor y Watson, 1971). ${ }^{68}$

(3) Contornos bien delimitados a nivel individual y vínculos fuertes a nivel grupal (strong-grid and strong-group). En tercer lugar, se refiere a aquellos tipos de trabajo tradicionales en las clases trabajadoras (traditional working-class occupations), tales como los trabajadores en el sector de la minería o los estibadores portuarios. Estos grupos de trabajadores se basan en la mutua interdependencia y en la definición de funciones o roles estratificados (wolves). En ocasiones el trabajo y la vida en grupo se fusionan en instituciones omniabarcantes como la convivencia laboral en prisiones, hospitales o algunos hoteles. En tales entornos el control que ejerce el grupo sobre el individuo puede llegar a ser considerable, exigiendo la dedicación de tiempo y la definición de lealtades.

(4) Contornos escasamente delimitados a nivel individual pero vínculos fuertes a nivel de grupo, aunque sean a menudo latentes (weak-grid and strong-group). En último lugar, se refiere a aquellos tipos de trabajo que ofrecen una considerable autonomía y libertad de movimientos, pero en los que tal libertad está sujeta a un control burocrático por clases que lleva a uniformizar a los trabajadores, clasificándoles en distintas unidades $\mathrm{y}$, por tanto, generando un sentimiento colectivo. Los trabajadores se sienten miembros de un grupo junto a sus compañeros de trabajo para algunos propósitos determinados, mientras que actúan de forma individualista y movidos por la competitividad en otros (vultures). No gozan de la libertad de los 'hawks', ni del encorsetamiento asfixiante que atenaza a los 'donkeys'. Su pertenencia al grupo no tiene los efectos intrusivos y controladores propios de una manada de lobos (wolves). Entre tales tipos de trabajo se encuentran los agentes comerciales o lo representantes de negocios. Los repartidores ejemplifican bien el grado de unidad en las condiciones laborales y tareas profesionales y la discrecionalidad y considerable libertad de cada miembro en el día a día de su trabajo. ${ }^{69}$

Como conclusión, se puede afirmar en líneas generales que el conocimiento de la psicología individual y colectiva en torno a cada tipo de trabajo resulta de utilidad para definir las estrategias de prevención y adaptar el necesario control a las características y circunstancias particulares, encontrando el punto de equilibrio entre confianza y control.

Aunque no se puedan establecer reglas generales que definan el modo en que interaccionan -a efectos criminológicos- los rasgos personales y las características del entorno laboral, se pueden tratar de identificar algunos nexos de unión entre tipos

\footnotetext{
${ }^{68}$ MARS, Cheats at Work, cit. nota ${ }^{\circ} 50$, p. 31.

${ }^{69}$ Cfr. MARS, Cheats at Work, cit. nota ${ }^{\circ} 50$, pp. 32-33.
} 
AGUSTINA, JOSÉ R. "Fenomenología del employee crime: Bases para definir Estrategias de prevención del delito intraempresarial".

de trabajo y características de los delitos más comunes, sus condiciones y lugares de ejecución (fiddle factors and fiddle-proneness). ${ }^{70}$

Así, el empresario debería conocer ex ante con mayor profundidad la potencialidad delictiva del entorno en que coloca a cada trabajador. Ciertamente, desde el punto de vista jurídico-penal será difícil que pueda asumir parte de responsabilidad si puso su confianza en una persona que no la merecía (culpa in eligendo), o si al otorgarle sus funciones y capacidades - tal vez por un exceso de confianza- omitió un sistema de vigilancia o de reducción de la oportunidades delictivas (culpa in vigilando). Sin embargo, la relevancia penal no es el único análisis posible respecto de una negligente estrategia preventiva.

\section{6. ¿Hacia una teoría general del delito intraempresarial?}

La realidad criminológica en el entorno de la empresa ha sido fuente de discusiones en torno a las distintas definiciones y clasificaciones de delitos, causadas por diferentes perspectivas de análisis, que en ocasiones han oscurecido el debate doctrinal, dotando a éste de cierto carácter nominalista. Los intentos criminológicos para describir y explicar la delincuencia en el entorno empresarial tratan de abordar la génesis y fenomenología delictiva en la empresa. El contexto no determina el tipo de delito, sino que tal vez pueda ayudar a explicar sus causas y las modalidades en que se desarrolla. En realidad, en la empresa se cometen distintos tipos de delitos, tanto comunes como especiales. Las oportunidades criminógenas no configuran per se tipos penales específicos, sino que simplemente describen los patrones delictivos asociados al contexto, en este caso, el lugar de trabajo y la posición que en él se ocupa.

La construcción de una teoría criminológica relativa a la delincuencia en la empresa puede tratar de ser omnicomprensiva, y así pretender englobar toda clase de delitos y cualquier categoría de sujeto activo. Sin embargo, debe tenerse en cuenta que (1) los perfiles psicológicos y las motivaciones que caracterizan al personal directivo y a los trabajadores presentan en general grandes diferencias -independientemente de la posición-; y (2) en algunos delitos, el contexto delictivo es una circunstancia no relevante: el entorno laboral no da explicación ni facilita -en tales casos- la comisión de algunos delitos, sino que se trata de hechos delictivos no específicos del ámbito laboral cuya realización responde a factores fundamentalmente personales.

Históricamente, en 1939 Edwin Sutherland introdujo por primera vez el concepto de 'white-collar crime' (delito de cuello blanco) para describir la conducta delictiva realizada por personas de alto nivel social y respetabilidad, que utilizan la posición que ocupan ('occupational position') como medio para vulnerar la legalidad. ${ }^{71}$ Esta primera definición vino a generar controversia en torno a su carácter excesivamente restrictivo, siendo irrelevante la categoría o clase social del delincuente. ${ }^{72}$ En 1970 Edelhertz definió el delito de cuello blanco como un acto ilegal cometido de forma imperceptible mediante engaño o subrepticiamente, para obtener dinero $u$ otras

\footnotetext{
${ }^{70}$ MARS, Cheats at Work, cit. nota ${ }^{\circ} 50$, pp. 136 y ss.

${ }^{71}$ SUTHERLAND, E.H., White-Collar Crime, New York, 1949.

72 BOOKMAN, Z.F., "Convergences and Omissions in the Reporting of Corporate and White Collar Crime”, Yale Law School Student Scholarship Series, 2007, paper 43, p. 14.
} 
propiedades, para evitar realizar un pago o perder dinero o propiedades, o para obtener una ventaja personal o profesional. ${ }^{73}$

La doctrina ha tratado de dividir los delitos de cuello blanco en dos grandes categorías: 'occupational crime' y 'corporate crime'. Así por ejemplo, partiendo de la definición de Sutherland, Sally S. Simpson entiende el corporate crime como una subcategoría de white-collar crime. ${ }^{74}$

Gary S. Green trató de reemplazar el término white-collar crime mediante su particular concepción del "delito ocupacional" (occupational crime), considerando que el distintivo énfasis en el status del sujeto activo del delito diferenciaba al whitecollar crime del occupational crime. Define éste último como cualquier acto sancionable según la ley que se comete a través de la oportunidad generada en el curso de una ocupación legal. ${ }^{75}$ Así, la comisión de un occupational crime no se distingue por la clase social del delincuente, sino que puede perpetrarlo cualquier persona sin importar la profesión o condición social del sujeto - 'in all walks of life'-, siempre que utilice un trabajo legal como oportunidad para perpetrar el delito. ${ }^{76}$ En este sentido, tanto el delito del empresario como el del trabajador son diferentes tipos de occupational crime que tienen en común la utilización del puesto de trabajo como medio para delinquir.

Sin embargo, aunque la ocupación confiera la estructura desde la cual se comete el delito o facilite que aparezcan ciertas formas de criminalidad, de ello no se sigue necesariamente que la dimensión ocupacional sea el rasgo más distintivo de la figura de delito. En este sentido, se ha criticado la tipología de delitos ocupacionales propuesta por Green. ${ }^{77}$

David O. Friedrichs realiza una análisis crítico de la utilidad, coherencia y claridad conceptual de los nuevos conceptos de "occupational crime", "occupational deviance" y "workplace crime”: no sólo han contribuido a mantener la confusión ya existente en torno a la naturaleza del "white collar crime", sino que -en su opiniónla han intensificado. A su juicio, para una adecuada distinción conceptual que tenga utilidad en la teorización sobre el delito, las investigaciones empíricas y la formulación de políticas, se debería (1) conservar el significado original asignado a "occupational crime" por Marshall Clinard y Richard Quinney, como aquellos delitos cometidos por personas individuales en el contexto de una ocupación legítima, con una motivación económica y cuya realización ha sido posible específicamente en virtud de la posición que se ocupa; (2) restringir la utilización del término "occupational deviance" a las acciones desviadas respecto de las normas internas en un entorno ocupacional, incluyéndose las normas establecidas por el empresario y las

\footnotetext{
${ }^{73}$ EDELHERTZ, H., The Criminal Elite, New York, 1970.

${ }^{74}$ SIMPSON, S.S., Corporate Crime, Law, and Social Control, Cambridge, 2002, p. 7.

${ }^{75}$ GREEN, G.S., Occupational Crime, 1997, p. 15.

${ }^{76} \mathrm{Vid}$. GREEN, Ibid., in principio. Aunque el término white-collar crime es utilizado en ocasiones para describer este tipo de actividad illegal, Green aporta una definición más precisa y la mismo tiempo más genérica de occupational crime, que englobaría las siguientes cuatro subcategorías: "organizational occupational crime, state authority crime, professional occupational crime, and individual occupational crime”.

${ }^{77}$ FRIEDRICHS, D.O., "Occupational crime, occupational deviance, and workplace crime: Sorting out the difference", Criminal Justice, Vol. 2, No. 3 (2003), pp. 243-256, p. 246.
} 
AGUSTINA, JOSÉ R. "Fenomenología del employee crime: Bases para definir Estrategias de prevención del delito intraempresarial".

que provienen de los compañeros de trabajo; y (3) preferiblemente se debería restringir el término "workplace crime" para designar formas de criminalidad convencionales que tienen lugar en el lugar de trabajo -desde homicidios, violaciones, acoso sexual, hasta hurtos y robos- ${ }^{78}$

Por el contrario, la conducta individual se inserta en ocasiones en una estructura formal que puede cobijar, proteger y fomentar el hecho delictivo. Así, el acto ilícito puede beneficiar simultáneamente a su ejecutor material de forma individual (occupational crime) y, a su vez, a la empresa a la cual representa (corporate crime). ${ }^{79}$ Sin embargo, ¿qué diferencia un delito meramente individual de una conducta criminal con dimensiones corporativas? La línea divisoria entre "occupational crime" y "corporate crime" presenta en algunos casos contornos difusos, sin tratarse de una cuestión meramente semántica. ${ }^{80}$

En este sentido, una de las definiciones más elementales del "corporate crime" describe el delito de empresa como aquella conducta de una empresa, o de los trabajadores actuando en representación de una empresa, que está prohibida y castigada por la ley (Braithwaite). ${ }^{81}$

Como subraya Sally S. Simpson en esta definición de corporate crime resaltan tres ideas principales: ${ }^{82}$ (1) la no especificidad del tipo de ley que prohibe y castiga la conducta punible: en este sentido, Braithwaite parece aceptar el argumento de Sutherland relativo a que la ilegalidad cometida por las empresas y sus agentes se diferencia respecto de las conductas punibles de las clases socio-económicas inferiores en el posible recurso a la sanción administrativa; ${ }^{83}$ (2) tanto la propia empresa -como persona legal o jurídica-, como sus representantes, son reconocidos como posibles autores, aunque contra quién se dirija el proceso penal dependerá de la clase de acción cometida, las normas y la calidad relativa a las pruebas, la decisión del fiscal y el modo en que se ha desarrollado el delito, entre otros factores; ${ }^{84}$ (3) la motivación esencial que caracteriza al corporate crime: la ilegalidad no ha sido perseguida sobre todo por un beneficio individual sino para conseguir fines corporativos.

Así, a partir de la definición de Braithwaite, Sally S. Simpson retrata certeramente el espíritu que anima todo corporate crime mediante algunos ejemplos: con la finalidad de mantener un nivel de beneficios empresariales, controlar un mercado difícil de

\footnotetext{
${ }^{78}$ FRIEDRICHS, “Occupational crime”, cit. nota ${ }^{\circ} 77$, pp. 253-254.

${ }^{79} \mathrm{Si}$ por el contrario, el delito beneficia a la persona y perjudica a la corporación estaríamos ante un occupational crime.

${ }^{80}$ Así, BOOKMAN, “Convergences and Omissions”, cit. nota $\mathrm{n}^{\circ} 72$, p. 15.

${ }^{81}$ Corporate crime is the "conduct of a corporation, or of employees acting on behalf of a corporation, which is proscribed and punishable by law" (vid. BRAITHWAITE, J., Corporate Crime in the Pharmaceutical Industry, London, 1984).

${ }^{82}$ SIMPSON, Corporate Crime, Law, and Social Control, cit. nota ${ }^{\circ} 74$, p. 7.

${ }^{83}$ SUTHERLAND, White-Collar Crime, cit. nota $\mathrm{n}^{\circ}$ 71, p. 9. Así, en la definición de corporate crime no sólo se incluyen hechos que vulneran la legalidad penal, sino también ilícitos civiles y administrativos.

84 "Both corporations (as "legal persons") and their representatives are recognized as illegal actors. Which or whether each is selected as a sanction target will depend on the kind of act committed, rules and quality of evidence, prosecutory preference, and offending history, among other factors" (SIMPSON, Corporate Crime, Law, and Social Control, cit. nota ${ }^{\circ} 74$, p. 7).
} 
predecir, reducir los costes de la compañía o dejar a otra empresa de la competencia sin posibilidades de competir, una empresa puede contaminar el medio ambiente, involucrarse en fraudes financieros u otras manipulaciones, fijar los precios, crear y mantener condiciones de trabajo arriesgadas, producir a sabiendas productos que no reúnen las condiciones de seguridad. Y se concluye: "las decisiones directivas para cometer tales actos -o para ordenar o apoyar tácitamente que otros los lleven a cabopueden llegar a estar respaldadas por normas internas de protocolo ['operational norms'] y subculturas organizacionales". ${ }^{85}$

En tal contexto, las formas de control empresarial que, más allá de tratarse de un esporádico caso puntual por un motivo excepcional, llevan a someter a los trabajadores a una vigilancia desproporcionada, no transparente o, en definitiva, inhumana, pueden revestir con facilidad las notas que describen un "corporate crime". Sin embargo, como se ha mencionado recientemente, en algunos casos no será fácil establecer la línea que separa (1) una cultura empresarial absolutamente arraigada y refrendada por la dirección de la empresa; (2) una subcultura empresarial ciertamente arraigada pero parcialmente conocida, tolerada o impulsada; y (3) un acto aislado de un trabajador o directivo que no puede atribuirse en ningún caso a una decisión corporativa.

La casuística puede ser enorme. Ciertamente, no siempre las políticas seguidas en una empresa son aprobadas o conocidas por quienes tienen formalmente el poder de decisión. Por ejemplo, el director de sistemas informáticos que no consulta a quien debe el acceso al contenido de un correo electrónico. O el directivo que desarrolla una auténtica política de control -no se trata de actos más o menos aislados- de espaldas al Consejo de Administración.

Las consecuencias de distinguir la responsabilidad individual y la corporativa son determinantes. Si se dirige el proceso penal contra un directivo de la empresa no supone necesariamente el final del negocio de la compañía, pero sí que podría causarse un daño irreversible si la acusación se presenta formalmente contra la corporación. ${ }^{86}$

\section{Fenomenología del delito intraempresarial en el marco de las estrategias de prevención de la criminalidad}

A continuación trataremos de presentar una descripción pormenorizada de los elementos comunes que caracterizan los delitos cometidos en el interior de la empresa. El conocimiento analítico de la criminalidad intraempresarial nos permitirá -en un segundo momento- separar y abordar con mayor claridad algunos problemas imbricados en el deber de vigilar y prevenir que recae sobre el empresario. Una tal clasificación permite la delimitación de diferentes grupos de casos en orden a distinguir estructuras de imputación de responsabilidad en función del deber de control empresarial.

\footnotetext{
${ }^{85}$ COLEMAN, J.W., The Criminal Elite, New York, 1989, citado en SIMPSON, Corporate Crime, Law, and Social Control, cit. nota ${ }^{\circ} 74$, p. 7.

${ }^{86}$ En este sentido, causaron cierto revuelo las directrices que en 2003 dirigió el entonces Deputy Attorney General Larry Thompson a las compañías, señalando qué debían hacer para evitar que la corporación fuese formalmente acusada: vid. BOOKMAN, "Convergences and Omissions", cit. nota ${ }^{\circ}$ 72, p. 15.
} 
Así, desde un punto de vista analítico, las características generalmente descriptivas de la criminalidad en el interior de la empresa o criminalidad "ad intra" presentan los siguientes rasgos fenomenológicos: (1) En primer lugar, estamos ante lo que hemos denominado un delito intraempresarial, es decir, ante -en cierto sentido- un "conflicto interno", una realidad criminológica intramuros que, por la naturaleza de la agresión antijurídica, deviene una "infracción pública" (de ahí la contraposición entre lógica de la empresa y la lógica del Derecho penal), ${ }^{87}$ (2) el núcleo del hecho antijurídico generalmente se fundamenta en un quebranto de las expectativas de fidelidad, es decir, estamos ante un delito de deslealtad en el que una de las partes protagoniza un abuso de confianza; (3) el modus operandi del autor pretende ser imperceptible al control, siendo el delito transparente (invisible crime); ${ }^{88}$ (4) por esa misma razón, en numerosas ocasiones la gravedad o el montante del hecho es objeto de fragmentación por el autor -siendo el delito una suma de actos aparentemente insignificantes que, considerados de forma aislada, podrían parecer injustos de bagatela-; es decir, con frecuencia estamos ante un delito continuado en el tiempo; ${ }^{89}$ (5) por las consecuencias sociales y económicas que conlleva es un delito de extrema gravedad, a pesar de que el daño sea, en ocasiones, difícilmente objetivable o identificable -en cierto modo la empresa es un bien jurídico colectivo o un interés difuso, ${ }^{90}$ en los que el nexo que une acción y daño (social harm) es débil-.; ${ }^{91}$ y (6) finalmente, se trata de un delito sin víctima aparente o al menos difícilmente identificable -el "occupational crime" como delito del que se aprovecha de los puntos débiles del sistema (free rider)-. En tal sentido, al ser la empresa el sujeto principalmente perjudicado se viene a difuminar la relación agresor-víctima.

Aunque no se refiera exclusivamente al delito intraempresarial, Jupp et al. realizan una descripción del "invisible crime" que explica bien las causas y consecuencias de tal invisibilidad: (1) "no knowledge”: el escaso conocimiento individual o público del

\footnotetext{
${ }^{87}$ Obsérvese la antítesis entre la dimensión pública de la ofensa y la naturaleza privada del contexto: la lógica empresarial de la oportunidad, el pragmatismo, la flexibilidad y la eficiencia conducen a rechazar prima facie la intervención del Derecho penal porque este último se orienta según principios, valores y objetivos — principio de legalidad, el castigo del comportamiento grave, procesos formales, etc.- que son distintos y, en ocasiones, opuestos a los de aquélla (en este sentido BUSSMANN, K.-D. (2003), "Business Ethics und Wirtschaftsstrafrecht. Zu einer Kriminologie des Managements", MschrKrim, 86, p. 93; y PASTOR MUÑOZ, N., La respuesta adecuada a la criminalidad de los directivos, 2006, p. 6).

${ }^{88}$ En la definición y clasificación de tipos de 'invisible crime' o 'hidden crime' que propone JUPP et $a l$, el primer delito invisible al que hace referencia es aquél que comete el trabajador contra las organización para la que trabaja; el segundo, el cometido por las empresas u organizaciones contra sus trabajadores (vid. JUPP, V.R., DAVIS, P., FRANCIS, P., 'The features of Invisible Crimes', 1999; vid. JUPP, V. en: MCLAUGHLIN/MUNCIE, The Sage Dictionary of Criminology, cit. nota n 5, p. 203).

${ }^{89}$ Las actividades delictivas en este tipo de contextos fueron ya definidas mediante la noción de continuum por HARDING y JENKINS en The Myth of Hidden Economy (1989): vid. DAVIS, P., FRANCIS, P., JUPP, V., Crime-Work Connections: Exploring the 'Invisibility' of Workplace Crime, en DAVIS, P., FRANCIS, P., JUPP, V., Invisible Crimes. Their Victims and their Regulation, 1999, p. 59. En este sentido, se afirma que los delitos pueden generarse en el lugar de trabajo en las junturas entre lo legítimo y lo ilegítimo (p. 54), abarcándose diferentes tipos de actos ilícitos desde delitos hasta pequeñas trampas, generalizándose la corrupción (p. 59).

${ }^{90}$ SILVA SÁNCHEZ, J.M., La expansión del Derecho penal, 2001, pp. 25-26, donde cita la definición de bien colectivo de Alexy como aquél que "es imposible dividirlo en partes", es decir, "bienes nodistributivos" (vid. ALEXY, R., "Derechos individuales y bienes colectivos", en su obra El concepto y la validez del Derecho (trad. J.M. SEÑA).

91 A cerca de la compleja relación entre dañosidad social, delito e inmoralidad, vid. MCLAUGHLIN/MUNCIE, The Sage Dictionary of Criminology, cit. nota n 5, p. 402.
} 
delito invisible puede deberse a la complejidad de los hechos, a la ausencia de vigilancia o a que se perciba como algo normal sin existir conciencia acerca del carácter delictivo; (2) "no statistics": la ausencia de datos estadísticos, en tanto que la víctima no denuncia los hechos, ya sea porque no es consciente o porque se siente amenazada o intimidada -o teme perder el puesto de trabajo-; (3) "no theory": la investigación criminológica históricamente se ha centrado en delitos de naturaleza patológica, asociados a otros contextos (street crimes); (4) "no research": la dificultad de acceso a la información es un obstáculo insalvable para llevar a cabo una investigación -por el hermetismo informativo del mundo empresarial-; (5) "no control": la complejidad del delito, el carácter difuso de los posibles delincuentes, los confusos límites que separaran lo que es legítimo de lo que ya no lo es, conllevan la ausencia de controles formales o sistemáticos; (6) "no politics": la agenda política no se ve urgida por tal tipo de delincuencia sin víctimas; (7) "no panic": los delitos invisibles no generan pánico emocional y no se refleja una imagen especialmente perversa de los autores en los medios de comunicación social; si bien en algunas ocasiones se centra la atención en aquellos casos puntuales más escandalosos, se diagnostica el caso como algo excepcional y no como un problema estructural del sistema. $^{92}$ El conjunto de rasgos que caracterizan al "invisible crime" están estrechamente relacionados y se implican mutuamente en numerosas ocasiones. Sin embargo, al margen de que coincidan todos ellos en cada supuesto delito intraempresarial, constituyen un modo eficaz para valorar la invisibilidad del delito en un contexto determinado. ${ }^{93} \mathrm{Y}$, sin duda alguna, deberán aportar importantes matices a la hora de justificar la intensidad, extensión y tipología del control del empresario.

\section{Comprensión de las estrategias de prevención del delito dentro de la empresa: análisis de consecuencias}

Veamos ahora qué efectos se derivan de la actitud y estrategia del empresario frentre al employee crime. Conviene tener presente para ello que quien ostenta una posición de vigilancia o control puede ser declarado responsable civil por los daños ocasionados por las personas a su cargo. Con esta consideración en mente se puede comprender la lógica oculta o explícita de las estrategias de prevención del delito en la empresa.

Por tanto, ¿cuáles son las consecuencias sociales que resultan de las premisas sobre las cuales se resuelven las demandas de responsabilidad civil derivada de delito $?^{94}$ En realidad, lo que sucede es que el posible vínculo o relación de causalidad entre las premisas sobre las que se justifica la responsabilidad civil del empresario y la prevención del delito en la empresa pueden generar dos tipos de actitudes: (1) aportar

\footnotetext{
${ }^{92}$ Es paradigmática a este respecto la forma en que se ha tratado en los medios de comunicación el caso Jérôme Kerviel, el broker de Société Générale que originó al banco francés unas pérdidas de 4.900 millones de euros. Se tiende a relativizar la gravedad de la conducta individual y a realzar el carácter perverso de las corporaciones (vid. las noticias aparecidas a partir del escándalo, por ejemplo la publicada por El País el 06/02/2008: "Kerviel rechaza convertirse en el chivo expiatorio de Société Générale").

${ }^{93}$ MCLAUGHLIN/MUNCIE, The Sage Dictionary of Criminology, cit. nota ${ }^{\circ}$ 5, pp. 203-204.

${ }^{94}$ El título de este apartado lleva por nombre el encabezamiento a las interesantes reflexiones en la materia efectuadas por J.E. Eck en "Do premises liability suits promote business crime prevention?" en FELSON, M., CLARKE, R.V., Business and Crime Prevention, cit. nota ${ }^{\circ} 12$, pp. 125-150.
} 
AGUSTINA, JOSÉ R. "Fenomenología del employee crime: Bases para definir Estrategias de prevención del delito intraempresarial".

un nivel adecuado de protección frente a riesgos previsibles y/o (2) simplemente, pueden elevar los costes de la actividad empresarial. ${ }^{95}$

Sin embargo, tales actitudes aparentemente contrapuestas pueden convivir en la lógica empresarial. Es decir, el análisis económico del derecho -en este caso, el valor económico de los costes derivados de un daño y su probabilidad- pueden llevar al empresario a discriminar en qué clase de riesgos compensa la no inversión en medidas de prevención. ${ }^{96}$

El cálculo de costes del empresario examinará de forma racional tanto el riesgo o probabilidad de que se cometa un determinado delito -así, para un empresario inmobiliario, el índice y probabilidad de que las inquilinas sufran una violación puede ser más elevado que el riesgo de delitos contra el orden socio-económico-; como el riesgo de resultar responsable civilmente del daño -así, las probabilidades de que el jurado encuentre justificado que se trataba de un riesgo previsible frente al cual el empresario debía haber adoptado ciertas medidas de seguridad para evitarlo-. Este tipo de reflexiones conducen a Eck a poner en duda que la responsabilidad civil por daños derivados de un delito pueda tener efectos en las políticas de prevención empresarial: su validez es tan sólo una hipótesis que dependerá -en todo caso- del tipo de actividad empresarial, la regulación jurídica aplicable y los tipos de delitos más comunes, entre otros factores. ${ }^{97}$

Hemos visto en líneas precedentes que la responsabilidad por daños se fundamenta en el deber por parte del empresario de proteger a aquellas personas que se hallan en su esfera de dominio y organización -trabajadores, clientes o terceros-. En términos criminológicos, los delitos ocurren cuando los potenciales delincuentes encuentran potenciales víctimas en lugares en los que no existen medios de control debidamente dispuestos (capable controllers). ${ }^{98}$ Sin embargo, en este ámbito, pueden traerse a la consideración las críticas al escaso efecto disuasorio que -especialmente en algunos casos- pueden tener las penas de multa en "delitos de cuello blanco". 99

En definitiva, los modelos y criterios de decisión empresarial pueden tener en cuenta distintas variables y formas de aproximación. Así, Eck distingue entre individual risks -riesgos de victimización de un delito grave sobre aquellas personas que son los habituales usuarios del lugar-y place risks -el riesgo de que en un específico espacio físico tenga lugar un tipo de delitos en un período de tiempo determinado-. El primero se podría calcular de forma simple dividiendo el número de delitos en un lugar -la empresa, en este caso-durante un período de tiempo, entre el número total de usuarios -en el mismo lugar y tiempo, lógicamente- (Clarke, 1984, Sherman, 1989). El segundo, resultaría de la división del número de lugares de ese tipo en los que se han producido ciertos delitos, entre el número total de lugares con tales

\footnotetext{
${ }^{95}$ Vid. ECK, Ibid., pp. 125-126.

${ }^{96}$ Obsérvese además que el coste podrá repercutirse en el consumidor final del producto mediante una elevación de los precios. Especial atención han despertado tales consideraciones en el ámbito de la responsabilidad por el producto y la responsabilidad médica -medical malpractice- (vid. ECK, "Do premises liability suits", cit. nota ${ }^{\circ} 94$, p. 125).

${ }^{97}$ Vid. ECK, "Do premises liability suits", cit. nota n 94 , pp. 128-129.

${ }^{98}$ Vid. COHEN and FELSON (1979), entre otros (vid. ECK, "Do premises liability suits", cit. nota ${ }^{\circ}$ 94, p. 127).

${ }^{99}$ En general, vid. SIMPSON, Corporate Crime, Law, and Social Control, cit. nota ${ }^{\circ} 74$.
} 
características, durante el mismo intervalo de tiempo. A este respecto, aunque desde otro punto de vista, Brantingham y Brantingham (1995) distinguen cuatro tipos de lugares: (1) lugares criminógenos, es decir aquéllos que por sí mismos generan delitos (crime-generators); (2) aquéllos que atraen al delito (crime-attractors); (3) aquéllos que se consideran neutrales (crime-neutral locations); $\mathrm{y}$, finalmente, (3) aquéllos que repelen a los delincuentes (fear generators) ${ }^{100}$ En este sentido, el espacio virtual que representa el correo electrónico e Internet tiene un fuerte poder de atracción de la delincuencia.

Conviene realizar una última consideración respecto a los límites respecto de la legitimidad de las políticas empresariales de no eliminar las condiciones del daño previsible y asumir como un coste más el acaecimiento de ciertos delitos. El análisis de costes no puede obviar ciertos límites éticos y la obligación del empresario de poner los medios para evitar un delito. ${ }^{101}$

Así, la empresa de metro que, conociendo estadísticamente el acaecimiento de delitos graves en una estación, omite la instalación de cámaras de seguridad. O la empresa de ocio que contrata monitores sin la debida experiencia a pesar de que se producen determinados accidentes que podrían evitarse mediante la contratación de personal más cualificado.

\section{Estrategias de prevención general, especial y situacional frente al delito en la empresa}

De acuerdo con la perspectiva que he desarrollado extensamente en otro lugar, ${ }^{102}$ la actividad de prevención del delito en la empresa se ordena tanto a evitar daños y costes directos en el patrimonio empresarial, como a enervar las acciones de responsabilidad contra el empresario por daños ocasionados a terceros. Es así misión fundamental de las estrategias de prevención adelantar las "barreras de protección" de bienes jurídicos mediante la adopción de medidas de alejamiento de riesgos o de protección de bienes jurídicos que, previsiblemente, puedan verse amenazados. Conforme a reglas de experiencia se pueden extraer estándares de diligencia a partir de la observación de reglas de probabilidad, resultando de tal proceso la objetivación de deberes de cuidado. Así, según vimos, tales deberes objetivamente exigibles realizarían una "atribución de conocimiento" al sujeto responsable: éste debiera haber tenido en cuenta una pauta de cuidado objetivo para evitar un resultado perjudicial para la empresa -las más de las veces, de naturaleza delictiva-. Esa tal atribución de conocimiento, configurando un concepto normativo de obrar diligente, se erige en fundamento de atribución de responsabilidad $\mathrm{y}$, por tanto, en norma jurídica vinculante.

\footnotetext{
${ }^{100}$ Vid. ECK, "Do premises liability suits", cit. nota n 94, p. 130.

${ }^{101}$ Un ejemplo extremo basta para apreciar la necesidad de ciertos límites: el conflicto que tiene lugar al interponerse una class action, por la que un grupo de personas demandan a una compañía automovilística que, tras conocer que un defecto de fábricación de un modelo de coche iba a suponer la muerte de un porcentaje de ususarios, tras el correspondiente cálculo de costes, decide no retirar o reparar el producto defectuoso (vid. Class Action, 1991, dirigida por Michael Apted).

${ }^{102}$ Puede consultarse AGUSTINA SANLLEHÍ, El delito en la empresa, cit. nota $n^{\circ} 1$, libro que recoge en gran medida el texto del presente artículo.
} 
AGUSTINA, JOSÉ R. "Fenomenología del employee crime: Bases para definir Estrategias de prevención del delito intraempresarial".

En el ámbito civil, el Derecho de daños analiza el fenómeno de causación de un daño desde una perspectiva que se interesa ante todo en buscar un remedio ex post facto, estableciendo soluciones de naturaleza principalmente compensatoria. En la medida en que tales mecanismos de compensación se apliquen correctamente, pueden incentivar también comportamientos precavidos, pero en todo caso, el mecanismo de responsabilidad civil se pone siempre en funcionamiento cuando ya se ha producido el daño. En este sentido, no existe en la dogmática civilista una categoría similar a los delitos de peligro o de actividad: si no hay daño, no existe responsabilidad civil. ${ }^{103}$

En la dogmática jurídico-penal, en cambio, distintas categorías doctrinales se sirven de los deberes de prevención como fundamento preponderante de atribución de responsabilidad. Así, los "delitos de peligro" ilustran de forma paradigmática la distinta perspectiva de análisis del Derecho penal. Sin embargo, también otras categorías y conceptos utilizados en la teoría jurídica del delito, como la noción del "deber de examen previo", el "desvalor de la acción" o la estructura de la "actio libera in causa", se apoyan, con mayor o menor intensidad, en la falta de previsión del agente.

En esta nueva etapa caracterizada por la "cultura del control" en una "sociedad de riesgos" que ha experimentado una "revolución tecnológica", la exacerbación de los deberes de prevención y vigilancia pueden hacer retroceder en el tiempo los deberes de examen y escrutinio en orden a lograr una mayor previsibilidad de posibles riesgos. En este sentido, la mayor capacidad de conocimiento y control de la realidad aumenta, sin duda, las posibilidades de anticipación y prevención de riesgos, ya sean éstos dolosos o culposos.

Ciertamente, en algunos casos el empresario se puede enfrentar a "colisiones de deberes" en un momento dado (T2), en las que en aras de la seguridad se deban lesionar intereses de privacidad, concurriendo una situación extrema que viene a provocar un necesario balance de derechos, deberes e intereses que, si en un momento anterior (T1) se hubieran previsto determinadas medidas preventivas estandarizadas, se podría haber evitado.

Así por ejemplo, si el empresario omite establecer una política de restricción y control en el uso de Internet incumpliendo una hipotética normativa existente en la materia y conociendo que, entre sus trabajadores, dos empleados habían sido condenados en el pasado por delitos de pornografía infantil. Uno de sus trabajadores advierte al empresario de la sospecha fundada de que uno de ellos está accediendo a contenidos de pornografía infantil, por lo cual el empresario decide entrar sin previo aviso en el ordenador e inspeccionar su historial de navegación y su correo electrónico para, a continuación, ponerlo en conocimiento de la policía (vid. ciertas similitudes con Doe v. XYC Corp.).

La negligencia en T1 conduce causalmente a la colisión en T2. La estructura causal es similar a la de la doctrina de la actio libera in causa, pudiendo imputarse a un momento anterior la situación de necesidad justificante. Siguiendo este razonamiento,

${ }^{103}$ Sin perjuicio del derecho sancionador de carácter administrativo. Vid. al respecto, SILVA SÁNCHEZ, La expansión del Derecho penal, cit. nota ${ }^{\circ} 90$, pp. 84 y ss., en relación a su "teoría del Derecho penal de tres velocidades". 
se puede afirmar que el empresario ha vulnerado el derecho a la intimidad del trabajador por una falta de previsión anterior que puede ser lejana en el tiempo, pero que infringe un deber normativo grave (actio libera in causa).

Sin embargo, la omisión objeto del reproche penal -o de la imputación civil de responsabilidad- tiene que resaltar por poseer una relevancia objetiva respecto de ciertos estándares de previsibilidad. Así, distintos criterios pueden fundamentar la relevancia objetiva de la omisión en las políticas de prevención empresarial, entre otros, las distintas normativas aplicables y el contexto particular del caso concreto. La jurisprudencia puede también ir distinguiendo grupos de casos que limiten los deberes de previsión en función del sector de actividad y de la cultura social predominante, en tanto que "siempre se podría ser más diligente". En ocasiones, sin embargo, la omisión será relevante por la ausencia de una batería de medios que, analizados individualmente, no resultarían significativos.

En casos como el que se acaba de plantear, se debería distinguir la posible justificación penal de la conducta, la procedencia laboral del despido posterior y la viabilidad de la posible demanda civil por daños por lesión de la intimidad. El grado de negligencia del empresario, su nivel de inexcusabilidad, pueden coadyuvar a distinguir aquellos casos en los que aunque se entienda que no ha habido delito contra la intimidad, no se puede exonerar de responsabilidad al empresario por los daños ante una supuesta demanda civil del trabajador.

\subsection{Prevención general (corporate identity, e-policy, compliance, whistleblowing).}

9.1.1. Prevención general positiva: compliance, business ethics y la concienciación de pertenencia a una comunidad. El fenómeno de los whistleblowers.

\section{a) Concepción comunitarista de la empresa y corporate identity}

En apartados anteriores analizamos la importancia de que el trabajador se integre adecuadamente en el lugar de trabajo como medio indispensable de socialización (vid. supra). La ausencia de vínculos de integración social del trabajador respecto de la empresa, su falta de identificación con la compañía, la carencia de motivaciones positivas desde el punto de vista psicológico o emocional puede considerarse, a este respecto, un factor causal del comportamiento delictivo en la empresa.

Desde un punto de vista criminológico, el concepto de identidad corporativa (corporate identity) representa una estrategia efectiva de prevención del delito. ${ }^{104}$ Por el contrario, una atmósfera de anonimato y el distanciamiento del trabajador respecto de la organización aumentan las probabilidades de que emerjan comportamientos delictivos.

En ese sentido, todas aquellas medidas que coadyuven a la mejor integración o identificación del trabajador con la empresa redundarán no sólo en un descenso de las probabilidades de comportamientos delictivos sino en una optimización de los recursos y de la marcha económica de la empresa. El trato humano que reciben los

${ }^{104}$ En este sentido BUSSMANN, K.-D., Causes of Economic Crime and the Impact of Values: Business Ethics as a Crime Prevention Measure, Zurich, 2003, p. 10. NEUBERGER, O., Führen und führen lassen, $6^{\text {th }}$ ed, 2002, Weinheim, Basel. 
AGUSTINA, JOSÉ R. "Fenomenología del employee crime: Bases para definir Estrategias de prevención del delito intraempresarial".

trabajadores en la empresa se presenta, desde esta perspectiva, como un factor decisivo. Así por ejemplo, se ha comprobado que las personas en el entorno laboral consideran más importante cómo se les trata que los resultados que de hecho obtienen: "when people think about justice, what is most in their mind is their relationship with other people and with institutions". ${ }^{105}$

Los mecanismos de identificación que conduzcan a compartir riesgos, uniendo la suerte del trabajador y de la empresa mediante la participación en su propiedad (por ej., los sistemas de retribución mediante stock-options), aunque pudiera demostrarse que facilita tal identificación o previene el delito, no reúnen un componente humanizador que, a largo plazo, puede ser de mayor efectividad.

b) El fenómeno de los "whistleblowers" 106

El delito corporativo (corporate crime) y la desviación organizacional suscitan complejos problemas legales. Sin embargo, previamente se plantea un obstáculo inicial, cual es, el relativo a las dificultades inherentes a identificar la existencia misma del problema, cuando se ha producido algún tipo de irregularidad. Es en este punto donde los sistemas de whistleblowing pueden llevar a cabo un valioso servicio. No obstante, los denunciantes son a menudo "recompensados" por su rectitud e ingenuidad, recibiendo sanciones injustas en su lugar de trabajo.

En el Derecho de los Estados Unidos y otros países anglosajones se advierte así desde hace unas décadas la tendencia a fomentar la conducta de aquellos sujetos, denominados whistleblowers, dispuestos a revelar la comisión de actuaciones ilícitas en el seno de la empresa para la que trabajan. Aunque en la política criminal española todavía no se ha planteado seriamente la conveniencia de incentivar estas revelaciones como un medio de prevención o descubrimiento de delitos, algunos textos internacionales apuntan ya en esa dirección. ${ }^{107}$

Por tales motivos, en el Reino Unido, la Public Interest Disclosure Act 1998 (PIDA) pretende proteger a los "whistleblowers de buena fe" de las posibles represalias que puedan tomar sus empleadores. No obstante, en los inicios de este tipo de medidas legislativas protectoras, conviene examinar el fenómeno de los whistleblowers desde una perspectiva sociológica y jurídica: ¿cuáles son las motivaciones que hay detrás de los whistleblowers?; ¿cómo responden las empresas e instituciones a este fenómeno?; ¿puede la ley proteger adecuadamente a aquellos trabajadores que se deciden a denunciar?; ¿qué efectos tendrá este tipo de legislaciones en los sistemas de

\footnotetext{
${ }^{105}$ LIND, E.A., "Procedural Justice and Culture: Evidence for Ubiquitous Process Concerns", en Zeitschrift für Rechtssoziologie, 24-36.

${ }^{106}$ An employee who reports employer wrongdoing to a governmental or law-enforcement agency. • Federal and state laws protect whistleblowers from employer retaliation. [Cases: Master and Servant 30(6.35); Officers and Public Employees 66. C.J.S. Employer-Employee Relationship §§ 69, 78; Officers and Public Employees $\S \S 121,150-158$.$] : cfr. al respecto BLACK'S LAW DICTIONARY$ (8th ed. 2004), voz whistleblower.

${ }^{107}$ Los pros y los contras de tal opción, así como los problemas dogmáticos que plantea la actuación de estos sujetos, son objeto de análisis en RAGUÉS I VALLÈS, R., “¿Héroes o traidores? La protección de los informantes internos (whistleblowers) como estrategia político-criminal”, InDret $\mathrm{N}^{\mathrm{o}} 364$ (julio de 2006).
} 
whistleblowing, en las prácticas habituales y en la cultura de las relaciones laborales y de la sociedad en general? ${ }^{108}$

La trascendencia social y mediática del caso Enron, una de las compañías más importantes de Estados Unidos - concretamente la séptima empresa más importante del país- con alrededor de 80.000 empleados y una capitalización bursátil de 68.000 millones de dólares, supuso, sin lugar a dudas, un punto de inflexión y puso de manifiesto la importancia de las denuncias internas de los propios trabajadores como mecanismo para sacar a la luz irregularidades y fraudes en el interior de la empresa. Sin embargo, cuando en agosto del 2001 un directivo envió un informe interno al presidente advirtiéndole que se estaban produciendo irregularidades contables a gran escala en la empresa, desconocía por desgracia que el presidente de la compañía también estaba implicado. ${ }^{109}$

Así, según los datos del estudio realizado por PricewaterhouseCoopers sobre el delito económico a nivel mundial (vid. supra), la primera fuente por la que se descubren fraudes internos son los medios de detección denominados por el informe "corporate culture". ${ }^{110}$ Hasta un $43 \%$ de los fraudes salieron a la luz a partir de lo que se denomina tip-off (soplos anónimos): un 21\% corresponde a tip-off interno, un 14\% a tip-off externo y un $8 \%$ whislte-blowing system. ${ }^{111}$

En Estados Unidos, el $77 \%$ de las empresas tienen sistemas internos para recibir y gestionar soplos anónimos, frente a sólo el 34\% en Europa central y del este y el $32 \%$ en Europa occidental. ${ }^{12}$ En ese país, a raíz de experiencias como la del caso Enron, se impuso la obligación a las empresas cotizadas de poner en marcha un sistema de recepción de denuncias procedentes de los propios trabajadores. Sin duda, las diferencias existentes en la cultura anglosajona en torno al trabajo constituyen un factor importante. ${ }^{113}$

A este respecto, la naturaleza de la acción del trabajador que decide desvelar una irregularidad en su empresa puede revestir distintas particularidades. Así, puede

\footnotetext{
${ }^{108}$ GOBERT, J., PUNCH, M., "Whistleblowers, the Public Interest, and the Public Interest Disclosure Act of 1988", The Modern Law Review Limited, 2000 (MLR 63:1, January), p. 25.

${ }^{109}$ Vid. United States Court of Appeals, Fifth Circuit. U.S., Plaintiff-Appellee, v. Jeffrey K. Skilling, Defendant-Appellant. No. 06-20885. November 13, 2007. Para un entendimiento de cómo salió a la luz el caso Enron, vid. COFFEE, J.C., JR, Gatekeepers: The Professions and Corporate Governance, 2006, p.p. 35-36.

110 "Economic crime: people, culture and controls", 4th biennial Global Economic Crime Survey, PricewaterhouseCoopers Investigations and Forensic Services \& Martin-Luther-University 2007, con la participación del prof. Dr. Kai Bussman, p. 10. Las otras dos fuentes de conocimiento de los fraudes son los métodos de control de la propia dirección de la empresa (corporate controls), con un $30 \%$, y otros mecanismos más allá del dominio de la empresa, con un $24 \%$-siendo sólo un 3\% proporcionado por las autoridades públicas-.

111 "Economic crime: people, culture and controls", cit. nota $\mathrm{n}^{\mathrm{o}} 110, \mathrm{p} .10$.

${ }^{112}$ Vid. cuadro en "Economic crime: people, culture and controls", cit. nota no 110, p. 23.

${ }^{113}$ Como apunta Antonio Argandoña, director de la cátedra de Responsabilidad Social del IESE, existe una gran diferencia cultural entre Europa y Estados Unidos en el modo de valorar la denuncia, incluso anónima, y su forma de proteger al denunciante. En Europa, muchas denuncias no tienen un propósito ético (evitar los daños que el fraude produce a inversores, clientes o trabajadores), sino que responden a deseos de venganza de empleados resentidos, a chantajes fallidos o a empleados que acumulan pruebas buscando protección y las presentan cuando pese a todo son despedidos (vid. SALVADOR R., "Levantar la liebre y acabar cazado", La Vanguardia 17 de febrero de 2008).
} 
AGUSTINA, JOSÉ R. “Fenomenología del employee crime: Bases para definir Estrategias de prevención del delito intraempresarial".

revestir los caracteres de (1) una acción prohibida por el deber de secreto; de (2) una acción obligatoria cuya omisión puede entrañar algún tipo de responsabilidad jurídica; o de (3) una acción supererogatoria, ${ }^{114}$ con un índice elevado de riesgos o consecuencias negativas difícilmente previsibles.

(1) No parece que el trabajador pueda, en virtud de una obligación de guardar secreto, cometer en tales casos un delito especial de descubrimiento y revelación de secretos del art. $199 \mathrm{CPE}$, que castiga al que "revelare secretos ajenos, de los que tenga conocimiento por razón de su oficio o sus relaciones laborales". El deber de secreto no alcanza "al encubrimiento de irregularidades o fraudes" $" 115$ y se encuentra limitado por la libertad de información del trabajador como ciudadano. ${ }^{116}$ Sin embargo, la falta de nitidez en la línea que distingue una mera irregularidad y un delito puede generar una zona gris en la que, en virtud de la buena fe contractual, el trabajador no deba revelar una irregularidad menor por los efectos desproporcionadamente lesivos que pueda tener sobre la reputación de la compañía.

Sin embargo, el tipo penal del art. 199 CPE protege también el secreto del que es titular el tercero con el que se entra en contacto a través de la relación laboral "por razón de su oficio". 117 Especialmente en estos casos, se pueden dar supuestos de colisión de deberes entre el deber de secreto profesional y el deber de denunciar, en los que prevalezca el deber de secreto.

En este contexto, puede resultar enervada la prohibición de guardar secreto -por su contenido material-, en tanto que se puede sostener que no existe obligación de guardar secreto contrario al bien común. En Teología moral, Tomás DE AQUINO sostuvo un principio similar al afirmar que "no es lícito recibir secreto alguno contrario al bien común". 118

En la resolución judicial de un recurso contra el sobreseimiento de un sumario criminal en un caso de aborto, un Tribunal argentino enjuició la naturaleza de la prueba de cargo producida por la imputada al exhibir su propio cuerpo y confesar maniobras abortivas al profesional de la salud. Al margen de lo discutible de la cuestión, el caso plantea un importante conflicto de derechos e intereses. El Tribunal vino a estimar válida la prueba, sin resultar afectado el principio que prohíbe la autoincriminacion - principio que opera siempre y cuando ya se haya dado inicio a la actuación preventiva o judicial-. En el caso, se dilucidó también si existía obligación de denunciar por parte del médico, concurriendo justa causa de revelación -el conocimiento de la perpetración del delito de aborto, cuyo bien jurídico protegido es

\footnotetext{
${ }^{114}$ Desde la filósofía moral se ha acuñado la denominación de actos supererogatorios para designar aquel tipo de acciones que son moralmente elogiables a pesar de que su omisión, si bien hasta cierto punto criticable, no infringe ningún deber moral (NINO, C.S. "¿Da lo mismo omitir que actuar? Acerca de la valoración moral de los delitos por omisión”, Revista jurídica argentina La Ley, Buenos Aires, t. 1979-c, 1979, p. 801-817).

${ }_{115}$ ALONSO OLEA, M., CASAS BAAMONDE, M.E., Derecho del Trabajo, Madrid, 1995, p. 286.

${ }^{116}$ Como ha afirmado la STC 6/1988, de 21 de enero, "no puede argumentarse en contra del lícito derecho a la libre información la sola consideración de que, con sus manifestaciones públicas [...se cause...] un daño a la imagen y prestigio del empleador".

${ }^{117}$ Vid. MORALES PRATS, F., Comentarios a la Parte Especial del Derecho Penal, 2002, p. 327.

${ }^{118}$ DE AQUINO, T., Suma Teológica, II-II, q. 68, a.1, BAC, Madrid, 1946, tomo VIII, p. 535.
} 
la vida, bien superior al resto de bienes protegidos por el ordenamiento jurídico- ${ }^{119}$ Así, la denuncia médica no puede constituir, en tales condiciones, un delito de violación de secretos en virtud del principio preponderante de promoción del bien común. No obstante, precisa el Tribunal que si bien ante un delito de acción pública sí existe el deber de denuncia, por el contrario, ante un delito de instancia privada, el médico ni puede ni debe denunciar. ${ }^{120}$

"Entre la perspectiva de la mujer abortante ${ }^{121}$ y el principio del bien común observada así la problemática desde la necesidad de no dejar impune un hecho de tal naturaleza- que subyacen en la cuestión, en el caso, debe preponderar la obligación de denunciar porque hay justa causa de revelación, que estriba en el conocimiento de la perpetración del delito de aborto, cuya protección constitucional se alza como un interés prometido sobremanera. Si se quiere, en palabras de Tomás de Aquino, “....revelar los secretos en perjuicio de una persona es contrario a la fidelidad, pero no si se revelan a causa del bien común, el cual debe siempre ser preferido al bien particular. Y por esto no es lícito recibir secreto alguno contrario al bien común...” (Suma Teológica, II-II, q. 68, a.1, BAC, Madrid, 1946, tomo VIII, p. 535)". ${ }^{122}$

¿La no revelación del secreto puede tener en algunos casos consecuencias jurídicopenales? Concretamente, la cuestión es si se pueden plantear supuestos en los que no se trate ya de una omisión del deber de denuncia sino que, ante la posibilidad de evitar daños o delitos mediante su revelación, se pueda imputar responsabilidad por omisión del resultado lesivo con posterioridad. Se trataría de examinar en tales casos si existe una posición de garante en virtud de injerencia, ante un conocimiento accidental en el contexto de una relación de secreto profesional. Un abogado que conoce las intenciones futuras de su cliente de cometer un atentado con múltiples víctimas mortales. Un asesor fiscal que advierte accidentalmente que su cliente está implicado en el blanqueo de capitales procedente de una red de prostitución de menores. ${ }^{123}$

(2) En cuanto a la posible obligación de revelar los delitos o irregularidades internas, el conocimiento y la inacción por parte del trabajador respecto de la comisión de un delito invisible puede ser considerado una participación omisiva penalmente punible o un deber de solidaridad cualificado (vid. supra).

\footnotetext{
${ }^{119}$ Considérese a este respecto lo que advierte Jescheck, citando jurisprudencia alemana (RG DStr 1936, p. 179; BGH Dallinger MDR 1973, p. 369), al afirmar que, en virtud de su vinculación natural, el padre tiene el deber para con el hijo de evitar una acción abortiva por parte de la madre (vid. JESCHECK, H., WEIGEND T., Tratado de Derecho Penal, 2002, p. 670).

${ }^{120}$ En este punto, el Tribunal se fundamentó en el Código de Ética de la Confederación Médica de la República Argentina (art. 70) que, en cuanto a la obligación de denunciar delitos, establece que "el médico sin faltar a su deber, denunciará los delitos de que tenga conocimiento en el ejercicio de su profesión, de acuerdo con lo dispuesto por el C.P. [Código Penal]. No puede ni debe denunciar los delitos de instancia privada contemplados en los arts. 71 y 72 del mismo código".

${ }^{121}$ En estos casos, la mujer urgida por la necesidad de asistencia médica -por razón de un aborto provocado por ella misma o por un tercero con su consentimiento-, se enfrenta incuestionablemente a una grave situación dilemática: o solicita el auxilio médico para conjurar el peligro en que se halla y entonces se expone a la denuncia del hecho, al proceso y a la condena criminal, o se resigna incluso a la posibilidad de perder la vida.

${ }^{122}$ Cfr. resolución de la Cámara Nacional Criminal y Correccional, Sala VII, fallo de 17-04-2007 (G.N. s/Sobreseimiento, Aborto (Instr. 33/170).

${ }^{123}$ Vid. FRIED, C., "The Lawyer as Friend: The Moral Foundations of the Lawyer-Client Relation" 85 Yale Law Journal 1060 (1976).
} 
AGUSTINA, JOSÉ R. "Fenomenología del employee crime: Bases para definir Estrategias de prevención del delito intraempresarial".

La prolongación en el tiempo del conocimiento especial del trabajador que conoce una práctica delictiva en su empresa introduce una diferencia relevante con aquellos casos relativos a lo que se denominan conductas neutrales, en las que un profesional se limita a actuar dentro de su rol sabiendo que está cooperando materialmente con un hecho delictivo. La duración en el tiempo puede llegar a convertir una simple infracción de un deber de solidaridad cualificado (omisión del deber de socorro) en una participación a título de cooperador necesario o de cómplice por omisión.

En este sentido, entendemos que el factor temporal incorpora un plus de antijuricidad relevante en el desvalor de la mera conducta neutral. Así, el directivo de una empresa que conoce que uno de sus clientes alquila un apartamento donde se ubicará un importante alijo de drogas. La enfermera que trabaja al servicio de un médico que practica abortos ilegales con periodicidad. El empresario con conocimiento de causa de que uno de sus clientes habituales compra material explosivo actuando como intermediario de una banda terrorista.

(3) En tercer lugar, conviene resaltar que alertar que se está cometiendo un fraude en la empresa puede ser una conducta ética pero, al mismo tiempo, peligrosa para los intereses del trabajador, en tanto que se expone a las represalias de los perjudicados por su acción. En tales circunstancias, la amenaza de un mal -como puede ser la pérdida del puesto de trabajo u otras amenazas de mayor gravedad-puede atenuar la obligatoriedad de revelar e incluso convertir su acción de naturaleza similar a los actos supererogatorios.

"La omisión de un acto supererogatorio, o sea el abstenerse de realizar un acto heroico o generoso, no viola las reglas de conducta de nuestro sistema moral que prescriben ciertos deberes mínimos hacia terceros, pero la realización de ese tipo de actos mostraría al agente como satisfaciendo exigencias de un ideal subyacente de excelencia humana. Por el contrario, un individuo que se atuviera estrictamente al cumplimiento de sus deberes, negándose en cambio, a ejecutar todo acto que vaya más allá de lo que las reglas morales exigen, no sería una persona inmoral que desconoce derechos legítimos de los demás, sino un hombre poco virtuoso que no ha desarrollado suficientemente su carácter moral. De este modo, la negativa a incurrir en todo acto supererogatorio que beneficiaría a terceros tiene efectos análogos a la realización de actos moralmente indignos que no perjudican a terceros (como dedicarse habitualmente al juego); en ambos casos tiene lugar una especie de "autodegradación" moral del sujeto, y nuestra crítica hacia él no está basada en lo que nos ha hecho o dejado de hacer sino en lo que él es, en lo que él ha hecho de sí mismo". ${ }^{124}$

El significado y los efectos de instrumentos legales como la PIDA (Public Interest Disclosure Act 1988) deben valorarse a largo plazo, en la incidencia que tengan respecto de los cambios en la cultura del lugar de trabajo y de la sociedad en general. En la base de este tipo de iniciativas del legislador, se halla el reconocimiento del servicio público que pueden realizar los whistleblowers. El concepto normativo de whistleblower como "un trabajador de buena fe que decide denunciar una irregularidad" se encamina a transformar la imagen del trabajador como fuente de

${ }^{124}$ NINO, C.S. “¿Da lo mismo omitir que actuar?, cit. nota n” 114, pp. 801-817. 
Polit. crim. Vol. 5, № 10 (Diciembre 2010), Art. 3, pp. 352-409.

[http://www.politicacriminal.cl/Vol_05/n_10/Vol5N10A3.pdf]

generación de problemas (industrial troublemaker) hacia la personificación del ciudadano responsable, preocupado por el bien común y el interés general. ${ }^{125}$

\section{b) Prevención general negativa: control del entorno, medidas disciplinarias y e-policy}

En el contexto de la prevención, mediante sistemas eficaces de detección y sanción de los delitos, incidentes e irregularidades perpetrados en el entorno de la empresa se pueden cumplir funciones de lo que se denomina por la doctrina penal y criminológica "prevención general negativa". Sin necesidad de acudir a la vía penal, el empresario puede establecer así, en el ejercicio de su poder disciplinario, un listado de infracciones y sanciones que, a efectos intimidatorios, pueda garantizar un nivel de eficacia preventiva suficiente, eficacia que será progresivamente mayor en proporción al nivel de certeza y rapidez con que se adopten las medidas disciplinarias como respuesta reactiva. ${ }^{126}$

En este contexto, recientemente, se ha comenzado a regular a través de la negociación colectiva el uso de Internet y del correo electrónico en las empresas. ${ }^{127}$ Entre las disposiciones en los convenios colectivos se prevén ciertas sanciones disciplinarias al respecto, por infracción de la política de la empresa en esta materia. En algunos convenios se empiezan así a establecer verdaderos "protocolos de actuación", abarcando un amplio espectro de posibles conflictos internos en el seno de la empresa. En este sentido, conviene resaltar el anexo 3 del VII Convenio colectivo de la empresa Unidad Editorial, S.A. ${ }^{128}$ Sin perjuicio del análisis que se realiza más adelante, se tienen en cuenta un elementos ciertamente relevantes si se pretende utilizar, en caso de necesidad, los mensajes de correo electrónico y el historial de navegación como documento de prueba fehaciente. Así, a fin de poder identificar y probar la autoría deberían arbitrarse medidas específicas dirigidas a evitar que un trabajador pueda utilizar libremente y sin control el correo electrónico o el acceso a Internet -e incluso al propio ordenador- de otro trabajador de la empresa. ${ }^{129}$

Desde un punto de vista pragmático, la creciente necesidad, conveniencia y eficacia relativa a la implementación de políticas empresariales respecto del uso del correo electrónico e Internet como medio de evitar la más que probable responsabilidad del

\footnotetext{
${ }^{125}$ GOBERT/PUNCH, "Whistleblowers, the Public Interest", cit. nota $n^{\mathrm{o}} 108$, p. 54.

${ }^{126}$ En cuanto a la relevancia del carácter automático e inmediato de la respuesta por parte de la empresa, vid. Stopping insider attacks: how organizations can protect their sensitive information, Security and privacy, IBM, September 2006, p. 9.

127 Para una visión detallada de la tipología de convenios hasta el momento y la evolución del fenómeno negocial en este ámbito, vid. GALÁN DURÁN, C., La reciente negociación colectiva en el ámbito del uso de Internet y del correo electrónico en las empresas, 2007, pp. 231-296; vid. también, al respecto, MORATO GARCÍA, R.M., "El control sobre Internet y correo electrónico en la negociación colectiva", Relaciones laborales, $\mathrm{n}^{\circ}$ 2, 2005.

${ }^{128}$ El contenido del anexo se emplea en distintos apartados de la cuarta parte como referencia y, como anexo a las conclusiones, donde se realiza un comentario a algunas de sus disposiciones (vid. BOE de 31 de octubre de 2005).

${ }^{129}$ Sea o no un uso premeditado que pretenda suplantar al trabajador, la ausencia de garantías podría hacer ineficaz la prueba documental aportada. En este sentido, vid. GALÁN DURÁN, La reciente negociación colectiva, cit. nota $\mathrm{n}^{\circ} 127$, p. 273 . A este respecto, como se señala en la importante STS 26-09-2007, El hecho de no establecerse clave de acceso personalizada -unido a la localización del ordenador en un despacho sin llave- aunque no suponga por sí mismo una aceptación por parte del trabajador de un acceso abierto a la información contenida en su ordenador, suscita "otros problemas [...] sobre la dificultad de la atribución de la autoría al demandante" (FJ 4, in fine).
} 
AGUSTINA, JOSÉ R. "Fenomenología del employee crime: Bases para definir Estrategias de prevención del delito intraempresarial".

empresario por un uso inadecuado de tales instrumentos por parte del trabajador ha dado lugar a un detallado ámbito de regulación. ${ }^{130}$

\subsection{Prevención especial: proceso de selección y deberes especiales de vigilancia}

En cuanto a las medidas de "prevención especial", el empresario debe ejercer un nivel de diligencia razonable en el conocimiento personal previo de sus trabajadores, de forma que puedan evitarse aquellos riesgos objetivamente previsibles que se deriven de sus condiciones personales en relación con el tipo de trabajo que se le va a requerir -antecedentes, predisposiciones, perfil psicológico-. Sin duda, los patrones objetivos de diligencia en la prevención delictiva pueden variar en función del carácter relevante que presenten unos determinados perfiles laborales en una sociedad hodie et nunc.

Así por ejemplo, en la sociedad norteamericana existe una especial sensibilidad social hacia el abuso de menores, ${ }^{131}$ de forma que se justifican sin excesivos aspavientos medidas intrusivas en la privacidad de los agresores sexuales en aras de las medidas de prevención social frente a tales riesgos y, en particular, a fin de facilitar las medidas de autoprotección de las propias víctimas.

Es decir, parece razonable que el empresario deba realizar un examen objetivo de adecuación de sus trabajadores, tratando de prevenir los riesgos previsiblemente más frecuentes derivados de la prestación laboral que se va a encomendar a cada empleado. En este sentido, la información requerida por el empresario para tal examen objetivo de adecuación del trabajador, se dirigiría a garantizar la ausencia de una indebida propensión criminal del candidato o, en el caso de haberla, asegurar que se suplirán los posibles déficits riesgosos con las oportunas medidas adicionales. Tales medidas podrían venir exigidas por la Ley o ser consecuencia de la diligencia media con la que debería contratar a sus trabajadores cualquier empresario razonable. El criterio jurisprudencial se acercaría, en este sentido, al parámetro objetivo ex ante del hombre medio en las circunstancias del autor, siendo en este caso las que rodean a un empresario medio en un determinado sector de actividad.

Desde un punto de vista ex post facto, ¿cuándo la información sobre el trabajador puede ser exigible al empresario? Es ciertamente un lugar común afirmar que "el poder se basa en la disposición de información" y, en ese sentido, la información otorga el poder de adecuar la conducta diligente a los riesgos conocidos ex ante.

En relación con los deberes positivos de prevención especial y el deber de control de trabajadores peligrosos por parte del empresario, la OIT, en el Repertorio de Recomendaciones Prácticas del documento "Protection of workers' personal data" (1997), estableció una serie de consideraciones que sugieren limitar un progresivo aumento de las medidas de control empresarial. Entre los elementos a tomar en cuenta en el balance entre prevención y seguridad podrían invocarse ciertos principios limitadores de la discrecionalidad empresarial en la petición de datos personales, en

\footnotetext{
130 Vid. FLYNN, N.L., The E-Policy Handbook, 2001, especialmente -por lo que respecta a las posibles formas de responsabilidad empresarial-, pp. 33-46; LEAHY, Monique C.M., "Employer Liability for Employee Misuse of Internet”, 105 American Jurisprudence Trials 1, Noviembre 2007.

${ }^{131}$ Tal vez como contrapeso a su decidida defensa del derecho a producir y consumir pornografía como estandarte de la libertad de expresión, pilar fundamental del orden constitucional norteamericano.
} 
tanto que "la recolección de datos sólo debería autorizarse con carácter excepcional y únicamente en la medida en que [...] tengan una relación directa con una decisión en materia de empleo".

A este respecto, la OIT precisa en el mismo documento una serie de casos que podrían justificar sólo de modo excepcional una solicitud de información por parte del empresario. Entre tales, se encuentra la petición de datos referidos a la vida sexual de los trabajadores. Así, cuando:

\begin{abstract}
"se trate de una acusación de acoso sexual, puede necesitarse una recolección de datos de ese tipo. Si hubiera procedimientos y obligaciones legales concernientes a una acusación de acoso sexual y si el empleador pudiera tomar medidas sobre la base de una investigación -por ejemplo, mediante un procedimiento disciplinario-, podrían recolectarse los datos necesarios para esa investigación. Esos datos deben estar en relación con la acusación y no ser utilizados más que para ese fin."
\end{abstract}

Respecto a la petición de antecedentes penales, "el acopio de datos debería limitarse exclusivamente a los que guarden una relación manifiesta con el puesto de trabajo". Si se trata, por ejemplo, de un empleo que se refiera al cuidado de niños, la persona interesada por ese puesto de trabajo que hubiese estado condenada por haber abusado de un menor de edad debería tener la obligación de declarar esta circunstancia. De modo análogo, en el caso de un conductor profesional podría exigírsele que diese a conocer las sanciones penales de que hubiera sido objeto por haber conducido en estado de embriaguez. El documento de la OIT concluye en este punto recomendando que los datos de este tipo "deberían obtenerse directamente del interesado, para tener la seguridad de no recabar sino la información pertinente". Por tanto, salvo que exista un motivo justificante, se recomienda un principio de general aplicación: "no se debería permitir que los empleadores pidan a los trabajadores que presenten una copia de sus antecedentes penales". ${ }^{132}$

Sin embargo, conviene distinguir los casos en que (1) la petición de datos es legítima, en el sentido de que no carece de justificación o es manifiestamente desproporcionada; de aquéllos en los que (2) la petición de datos por parte del empresario es preceptiva, en el sentido de que en caso de haber omitido un examen de idoneidad o ausencia de peligrosidad del trabajador puede ser causa suficiente de imputar el resultado lesivo al empresario.

En este contexto, se podría justificar la legitimidad, conveniencia e incluso obligatoriedad de ejercer ciertos controles periódicos sobre el posible consumo de drogas (drug testing) en aquellos trabajadores directamente responsables de la vida de terceros: personal de cuerpos policiales, pilotos de aviación, controladores aéreos, conductores de transporte escolar. ${ }^{133}$ No obstante, la ausencia de un examen médico de las condiciones físicas del candidato o el hecho de no haber recabado cierta información relevante podrían tener carácter inexcusable en caso de cometerse un

\footnotetext{
${ }^{132}$ Vid. Repertorio de recomendaciones prácticas en materia de Protección de los Datos Personales de los Trabajadores, Oficina Internacional del Trabajo (Protection of workers' personal data), Ginebra, 1997, epígrafe 6.5 .

${ }^{133}$ ETZIONI, A., The limits of privacy, 1999, pp. 7-8.
} 
AGUSTINA, JOSÉ R. “Fenomenología del employee crime: Bases para definir Estrategias de prevención del delito intraempresarial".

delito imprudente que se pudo evitar mediante el seguimiento de medidas de prevención estandarizadas.

La pregunta clave en este punto es si puede el empleador presuponer que si el candidato omite declarar un motivo objetivo de riesgo -que aumenta considerablemente las posibilidades de causar daños a terceros o le incapacita de algún modo para ese puesto de trabajo-, ello le autoriza para considerar idóneo al trabajador, sin asumir riesgos. No cabe duda a este respecto que, en caso de que el empresario haya establecido ciertas medidas positivas de carácter rutinario -a fin de recabar aquella información del candidato-, será más difícil inculpar al empresario por contratación negligente.

Entre otras distintas formas de imputación del resultado lesivo, la jurisprudencia norteamericana ha elaborado sobre la base de la ya mencionada "teoría de la negligencia empresarial en la contratación" en orden a examinar aquellos casos en los que el empresario puede ser declarado responsable civilmente por un daño causado por uno de sus trabajadores (vid. al respecto, lo señalado supra).

De este modo, la jurisprudencia norteamericana viene fundamentando los deberes empresariales en la previsibilidad, en tanto factor previo necesario en donde basar el correspondiente deber. Así, en Federico v. Superior Court (1997) se estableció que el deber del empresario respecto de no ser negligente en la contratación se infringe "sólo cuando el empresario conoce, o debiera conocer, elementos de hecho que alertarían a una persona razonable de que la contratación de un trabajador presenta riesgos indebidos de lesionar a terceras personas a la luz del específico tipo de trabajo que se le va a encomendar". ${ }^{134}$ A tales efectos, la negligencia empresarial en la contratación depende de la probabilidad de que un trabajador actúe de una determinada forma lesiva, sin ser relevante si la acción del trabajador es inocente, negligente, intencional o delictiva. ${ }^{135}$ "En suma, la piedra angular de la teoría de la negligencia en la contratación radica en que existiendo un riesgo de que el trabajador actúe de una determinada manera, efectivamente actúe de tal forma conforme a ese riesgo". ${ }^{136}$

No obstante, se puede interponer la acción por daños derivados de un delito del trabajador -o una mera conducta lesiva, como se acaba de apuntar-, fundando la demanda en cualquier tipo de negligencia empresarial a lo largo de la relación contractual, habiendo tenido lugar en el momento de la contratación, en la debida formación del trabajador, en la necesaria supervisión o en la retención indebida de un trabajador inadecuado (cause of action for negligent hiring, training, supervising, or retaining of an unfit employee).

En cuanto a los principales factores que tienen en cuenta los tribunales al decidir un caso de posible negligencia en la contratación, éstos se pueden sintetizar en los siguientes: (1) el nivel de diligencia observado por el empresario en la adopción de decisiones relativas al personal; (2) la limitación en razón de a quiénes obliga el deber de diligencia; (3) qué característica específica concurre en el trabajador que manifieste su incompetencia y el grado de evidencia con que aquélla se puede llegar a

\footnotetext{
${ }^{134}$ Cfr. Federico v. Superior Court (1997) 59 Cal.App.4th 1207, 1214.

${ }^{135}$ Cfr. Evan F. v. Hughson United Methodist Church (1992) 8 Cal.App.4th at p. 836.

${ }^{136}$ Cfr. Doe v. Capital Cities (1996) 50 Cal.App.4th at p. 1055.
} 
apreciar; (4) si la propia incompetencia del trabajador fue la "causa próxima" del daño alegado por el demandante; (5) si existe vinculación entre el empresario y el demandante. ${ }^{137}$ Un criterio adicional -relevante especialmente en casos delictivos- es el relativo a (6) si el empresario puede ser responsable directo por negligencia en la contratación o retención del trabajador cuando conocía o debería haber conocido la peligrosa proclividad relativa al trabajador (employee's dangerous proclivities). ${ }^{138}$

Además, es extremadamente relevante el hecho de que el empresario puede ser declarado responsable por "negligencia en el mantenimiento en el puesto de trabajo" a pesar de que podría no serlo bajo los criterios -más restrictivos en cuanto al ámbito objetivo- de la doctrina "respondeat superior". ${ }^{139}$

Con todo, la pretendida previsibilidad y los posibles deberes de informar a terceros pueden tener efectos desproporcionados en innumerables ámbitos -no sólo el de la contratación de los trabajadores- si no se delimita jurisprudencialmente su alcance.

Así, en University of Maryland Eastern Shore v. Anthony F. Rhaney (Jr.Md.Spec.App.2004. Cit. in diss. op.), el demandante, tras ser agredido (assault) por su compañero de habitación en el college donde residía, interpone acción civil por daños contra la Universidad por negligencia, alegando que no se le había revelado que su compañero de habitación tenía un perfil peligroso con propensión a la violencia. En segunda instancia el Tribunal sostuvo que la Universidad no infringió su deber de cuidado (duty of care) respecto del estudiante agredido por el mero hecho de que no exigiera al agresor que residiera por su propia cuenta fuera del campus universitario. Las pruebas respecto de la peligrosidad previa en la conducta del agresor fueron insuficientes para establecer que el daño fuera previsible.

Los parientes de un trabajador que fue asesinado por un compañero de trabajo demandaron al Estado por omitir el seguimiento de tal trabajador en régimen de libertad vigilada (parole), y al Ayuntamiento por contratar a tal trabajador omitiendo advertir a la víctima de sus peligrosas propensiones (Cal.App.1986. Cit. in case quot. in disc., subsec. (a) cit. in disc.). No obstante, el Tribunal mantuvo que ni el Estado ni el Ayuntamiento estaban vinculados por un deber legal respecto de la víctima. Por el contrario, sostuvo que aunque el Ayuntamiento fue negligente en no haber advertido a la víctima -que le había presentado un informe de haber sufrido acoso sexual- de las peligrosas propensiones de su compañero de trabajo -en relación a sus anteriores condenas por violación, secuestro y agresión sexual-, no obstante, subrayó que, cuando una relación especial entre el demandado y un tercero origina un deber por parte del demandado de ejercer un control sobre éste, la advertencia a previsibles víctimas es sólo una entre muchas otras formas mediante las que el demandado puede liberarse de su deber. Podría ser razonable para el demandado reducir su libertad de movimientos o, por el contrario, controlarlo directamente o tratar de ejercer influencia sobre él (Duffy v. City of Oceanside, 179 Cal.App.3d 666, 224 Cal.Rptr. 879, 882).

\footnotetext{
${ }^{137}$ Vid. WOSKA, W.J., "Negligent Employment Practices", 42 Lab. L.J., 603-04 (1991).

${ }^{138}$ Vid. Gaines v. Monsanto Co., 655 S.W.2d 568, 570 (Mo. Ct. App. 1983), sobre la responsabilidad del empresario por el asesinato de una secretaria a manos de un empleado en base a que conocía o debía haber conocido las condenas previas por violación y robo de trabajador.

${ }^{139}$ Cfr. al respecto, SCALES, M., "Employer catch-22: the paradox between employer liability for employee criminal acts and the prohibition against ex-convict discrimination", George Mason Law Review, Winter 2002, p. 3.
} 
AGUSTINA, JOSÉ R. “Fenomenología del employee crime: Bases para definir Estrategias de prevención del delito intraempresarial".

\subsection{Prevención situacional (broken windows y hot-spots)}

\subsubsection{La prevención situacional del delito en la empresa}

Como señalaron con acierto Marcus Felson y Ronald V. Clarke, la mayoría de las teorías criminológicas han prestado atención de forma preponderante a la persona del delincuente, planteándose por qué ciertos individuos tienen una mayor inclinación al delito. Ante esa excesiva focalización de la investigación criminológica, el punto de partida de sus "teorías de la prevención situacional del delito" encuentran su fundamento en que comprender la causación del delito no requiere remontarse a factores distantes que se encuentran fuera del alcance de la práctica diaria -la educación recibida, la configuración genética del delincuente, los procesos psicológicos o sociales-, sino en entender que el comportamiento humano individual es producto de una interacción entre persona y entorno físico. ${ }^{140}$ En las características relevantes de cada escenario delictivo se configura el entorno que ayudará al individuo a convertir las inclinaciones delictivas en acción. ${ }^{141}$ Por tanto, la prevención situacional del delito interviene en aquellas causas que el delincuente encuentra o busca en las circunstancias inmediatas del hecho delictivo. ${ }^{142}$ Así, el desarrollo de conceptos tales como "oportunidad" (opportunity), "actividad rutinaria" (routine activities) y "toma de decisiones racional" (rational decision-making) han tenido un profundo impacto en el desarrollo práctico de la prevención situacional de la delincuencia (Clarke, 1992). ${ }^{143}$

Como es lógico, el problema estriba en lo impredecible de la libertad humana y la desigualdad de los antecedentes que cada persona trae consigo hasta el momento de la oportunidad delictiva. El análisis empírico sobre las reglas de interacción entre las propensiones individuales al delito y las características criminógenas del escenario se enfrenta así a escollos difícilmente superables. ${ }^{144}$ Sin embargo, en el marco de la distinción entre condición y causa se afirma que la oportunidad -más que otras causas- es necesaria y, por consiguiente, tiene tanto o más derecho a ser considerada

\footnotetext{
${ }^{140}$ La prevención situacional del delito es una teoría de gran alcance, al concebirse como una tarea cuya responsabilidad debe ser asumida por toda la sociedad, y no únicamente por las agencias de control social formal o del sistema judicial: vid. MEDINA ARIZA, J.J., "El control social del delito a través de la prevención situacional", Revista de Derecho Penal y Criminología, núm. 2 (1998), pp. 281-323. Valorar la incidencia de la oportunidad como causa delictiva -junto a variables personales y sociales- supone una nueva visión de las políticas de prevención: vid. FELSON, M., CLARKE, R.V., “Opportunity Makes the Thief”, Police Research Series, Paper 98, London, 1998, p. 34.

${ }^{141}$ Vid. FELSON/CLARKE, “Opportunity Makes the Thief”, cit. nota no 140, p. 1.

${ }^{142}$ Vid. MCLAUGHLIN/MunCIE, The Sage Dictionary of Criminology, cit. nota ${ }^{\circ}$ 5, p. 383.

${ }^{143}$ MCLAUGHLIN/MUNCIE, The Sage Dictionary of Criminology, cit. nota ${ }^{\circ}$ 5, p. 280; CLARKE, R.V., Situational Crime Prevention: Successful Case Studies, New York, 1992.

${ }^{144}$ Vid. FELSON/CLARKE, "Opportunity Makes the Thief”, cit. nota no 140, p. 2, donde se alude a las objeciones éticas que presenta la experimentación mediante la creación de tentaciones delictivas, así como a la complejidad de los análisis estadísticos sobre el discernimiento de causas individuales. Conviene referirse también a las dificultades inherentes para establecer correlaciones causales en el estudio de conductas humanas y su relación con la libertad (vid. II., primera parte). Sobre la legitimidad moral de las técnicas de prevención situacional puede verse las críticas de Von Hirsch (1996) (vid. MEDINA ARIZA, El control social del delito, cit. nota n ${ }^{\circ} 140$, pp. 313-317) y el análisis de las cuestiones éticas sobre la video-vigilancia (vid., II.2., tercera parte).
} 
una "causa última", ${ }^{145}$ aunque, en atención al posible "efecto desplazamiento", quizá convendría referirse a la oportunidad como condición de posibilidad.

A la luz de este nuevo enfoque de acercamiento práctico al delito y su entorno, Felson y Clarke describen una cierta convergencia entre las tres nuevas teorías -o "enfoques", ${ }^{146}$ en realidad- relativas a la oportunidad delictiva: (1) tanto respecto del primer enfoque, denominado teoría de la actividad rutinaria (routine activity), como del segundo, (2) la teoría del patrón delictivo y del tercero, (3) la perspectiva de la elección racional.

La "teoría de la actividad rutinaria" tuvo su origen como explicación de los delitos depredatorios (Cohen y Felson, 1979). Partía de la base de que para que tales delitos tengan lugar se requiere la convergencia en el tiempo de tres elementos esenciales -ya anteriormente mencionados-: un posible delincuente (en una situación determinada), un objetivo apropiado y la ausencia de una vigilancia adecuada (de acuerdo con un concepto natural de vigilancia). ${ }^{147}$ En este sentido, de conformidad con el análisis adelantado por Gerald Mars (vid. supra), se podría tratar de aplicar esta perspectiva situacional a los distintos perfiles laborales de los trabajadores. De esta forma, se podría trazar una estrategia preventiva particularizada en función de los factores criminógenos, tanto generales - de cada tipo de trabajador y sus funciones en la empresa-, como situacionales -de acuerdo con la ubicación de los posibles objetivos y las carencias concretas en la vigilancia-. Si existe algún sector especialmente propicio y fecundo en el que pueda tener especial influjo la teoría de la actividad rutinaria éste es sin duda el de la delincuencia intraempresarial. No sólo como teoría que aporta una explicación fenomenológica respecto de dónde surge el hecho delictivo, sino porque conduce a descubrir la causación criminógena de conductas delictivas entre "personas normales" (vid. supra), a partir de la ausencia de controles internos y de dispositivos de vigilancia natural en la vida interna de la empresa. ${ }^{148}$

En la identificación de la oportunidad de cometer un delito como factor relevante ("opportunity makes the thief") se encuentra implícita la distinción entre medios cognitivos y medios normativos. Desde las teorías de la prevención situacional, se tratará de convertir el entorno, en términos cognitivos, en un escenario resistente al delito (crime-resistant), modificando las condiciones mediante el sentido común

\footnotetext{
${ }^{145}$ FELSON/CLARKE, “Opportunity Makes the Thief”, cit. nota no 140 , p. 2. Tal vez sería preferible la utilización del concepto "causa última" (razón en la mente de la persona) en lugar de "causa próxima" (condición de su realización hodie et nunc). Mientras el primer concepto requiere una gradación de factores y condiciones (distintas condiciones o causas en un mismo caldo de cultivo), el segundo se refiere con mayor precisión a la oportunidad como condicionante último o factor desencadenante. En cuanto al concepto de causa próxima como la última causa en el tiempo en el Derecho inglés, vid. Pink v. Fleming (1890).

${ }^{146}$ Según los mismos autores, tiene más sentido referirse a enfoques que a teorías, en tanto no se trata de teorías formal y completamente definidas (vid. FELSON/CLARKE, "Opportunity Makes the Thief”, cit. nota $\mathrm{n}^{\mathrm{o}} 140$, p. 3). Para la distinción entre teorías de la criminalidad y teorías del crimen, vid. Gottfredson y Hirschi, 1990; MEDINA ARIZA, El control social del delito, cit. nota n 14., p. 283.

${ }^{147}$ El vigilante no debe ser necesariamente un agente de seguridad, sino cualquiera que mediante su simple presencia

${ }^{148}$ Tal vez no se apliquen directamente las conclusiones relativas a los delitos predatorios (por ej., el hecho de que cuanto más tiempo se halla la persona entre desconocidos y fuera de su propio hogar, mayor es el riesgo de victimiación personal y patrimonial), aunque es evidente que la sola presencia, visibilidad y disponibilidad del empresario es -en este sentido y en muchos otros- un factor decisivo en la empresa.
} 
AGUSTINA, JOSÉ R. "Fenomenología del employee crime: Bases para definir Estrategias de prevención del delito intraempresarial".

aplicado a las precauciones rutinarias (routine precautions: Clarke, 1997). Así, se definirán estrategias que incidan en el diseño de los productos, servicios, sistemas o ambientes -en la empresa o en otros contextos-, ya sea implementándolas de forma aislada o conjuntamente con otras acciones sociales tales como la vigilancia o las funciones presenciales de determinadas personas. ${ }^{149}$

La "teoría del patrón delictivo" analiza cómo se mueven en las coordenadas espaciotemporales aquellos sujetos y objetos involucrados en un hecho delictivo. ${ }^{150}$ Los elementos descriptivos que toma en consideración son tres: (1) los nodos de actividad, es decir, los movimientos de los individuos -desde dónde y hasta dónde se trasladan las personas-, en tanto que pueden determinar la localización de hot-spots interrelacionados; ${ }^{151}$ (2) las rutas entre tales nodos: siendo así que cada delincuente busca los objetivos delictivos alrededor de los nodos de actividad personal -domicilio, lugar de trabajo, zonas de ocio- y las rutas entre ellos; ${ }^{152} \mathrm{y}$, como consecuencia de lo anterior, (3) se establecen unos límites, es decir, aquellos confines del área donde los individuos habitan, trabajan, se relacionan y satisfacen sus necesidades -compras, ocio, relaciones sociales, etc.--

En relación a los límites, la distinción entre propios y extraños ayuda a subrayar su importancia: la configuración de barrios en las poblaciones urbanas influye en los lugares de comisión de delitos -es más seguro delinquir en los límites o más allá de los mismos y retirarse posteriormente a su área-. Es posible reducir los índices de criminalidad mediante intervenciones en el diseño y administración de poblaciones, ciudades, áreas comerciales que geográficamente tengan tasas de delito elevadas -por ejemplo, incidiendo en la orientación de las ventanas se puede generar una vigilancia natural por parte del vecindario-. ${ }^{153}$

Finalmente, la "perspectiva de la elección racional" surge al ampliarse el abanico de factores que deben considerarse en el concepto de oportunidad, aumentando la complejidad resultante de los modelos. En esta línea, Clarke presenta un modelo de estructura de la oportunidad delictiva que incorpora elementos tales como la estructura socio-económica, la percepción, el entorno físico y el proceso de información (Clarke, 1995). Esta forma de indagar en el delito se empezó a solapar con la visión del delincuente -reminiscencia de las teorías clásicas- como un sujeto motivado por el propio interés. ${ }^{154}$ La perspectiva de la elección racional (the rational choice theory) entiende que el mecanismo causal fundamental que debe utilizar las teorías de la prevención situacional debe centrarse en (1) aumentar el riesgo asociado

\footnotetext{
149 Vid. MCLAUGHLIN/MUNCIE, The Sage Dictionary of Criminology, cit. nota no 5, pp. 383-384. En el ámbito de la empresa se pueden implementar numerosos mecanismos de reducción de la oportunidad de comportamientos desviados. Desde el mero hecho de pedir cuentas al trabajador con la debida periodicidad, hasta revisar facturas de modo que constante y siendo una práctica que es conocida por los trabajadores, establecer firmas mancomunadas en las cuentas, implementar mecanismos de control sobre el uso de la fotocopiadora, etc.

${ }^{150}$ Vid. FELSON/CLARKE, “Opportunity Makes the Thief”, cit. nota no 140, p. 6.

${ }^{151}$ Así por ejemplo, un bar conflictivo puede generar más delitos fuera del local que en su interior (FELSON/CLARKE, “Opportunity Makes the Thief”, cit. nota $\mathrm{n}^{\circ} 140$, p. 6).

${ }^{152}$ Las rutas seguidas por las personas también están estrechamente relacionadas con los lugares donde son víctimas de un delito. La teoría del patrón delictivo se interesa por la distribución geográficamente el delito (mapas de delito).

${ }^{153}$ FELSON/CLARKE, “Opportunity Makes the Thief", cit. nota n 140 , p. 6.

${ }^{154}$ Cfr. MCLAUGHLIN/MUNCIE, The Sage Dictionary of Criminology, cit. nota $\mathrm{n}^{\circ}$ 5, p. 279.
} 
a la perpetración de específicos tipos de delitos (deterrence), y (2) requerir un mayor esfuerzo y/o proporcionar una menor recompensa por el delito (discouragement), o hacer menos confortable (removing excuses) su ejecución (Clarke, 1997). ${ }^{155}$

\subsubsection{La omisión de políticas de prevención situacional}

$\mathrm{Al}$ analizar las reflexiones que llevaban a poner en duda que la responsabilidad civil por daños derivados de delito pueda tener efectos en las políticas de prevención empresarial (vid. supra), se apuntó que la validez de una tal correlación se veía amenazada por la tendencia a evaluar la posible responsabilidad por daños en el conjunto del análisis de coste-beneficio de la empresa.

Conviene realizar, no obstante, algunas referencias a los elementos que pueden limitar o facilitar la declaración de responsabilidad civil del empresario, como pueden ser el tipo de actividad empresarial (probabilidad), la regulación jurídica aplicable (deberes estandarizados), y los tipos de delitos más comunes (gravedad del riesgo). No se incluyen -por tratarse de casos meridianamente claros a efectos civiles- aquellos patrones de riesgo de mayor gravedad que se aproximan al dolo eventual (vid. lo referido a los supuestos de "ceguera voluntaria" [wilful blindness]).

La combinación de los tres elementos en el caso concreto puede aportar argumentos objetivos que definan aquel deber de diligencia que un empresario medio habría observado en el supuesto particular objeto de análisis. Desde esta perspectiva, planteamos -a modo de prototipo- el examen de la posible responsabilidad por omisión de una empresa de metro que no instala cámaras de seguridad, ni despliega un dispositivo de vigilancia personal, ante los repetidos delitos cometidos en un punto peligroso dentro de su esfera de dominio, siendo así que con la introducción de tales medidas se habría descubierto o evitado la comisión de un concreto hecho delictivo. Es decir, ¿existe posición de garante en relación con las agresiones o atentados sufridos por los usuarios de la red metropolitana?

Emplearemos un caso real con ciertas similitudes, el recogido en la STS 20-12-2004 y que es objeto de comentario por Gómez Pomar:

"El 19 de septiembre de 1993, Dña. Regina, de 31 años, casada con D. José Luis, y con dos hijos, se encontraba en la estación de metro de Can Boixeras, de l'Hospitalet de Llobregat, cuando fue agredida por Rosendo. La agresión tuvo lugar antes de que la víctima hubiera marcado su billete multiviaje en el dispositivo electrónico de control de los pasajeros. A resultas de aquélla, la víctima falleció tras recorrer agonizante unos 45 metros en el vestíbulo de la estación sin que ningún empleado del metro o de seguridad se hallara presente y la atendiera. Rosendo fue condenado por la Audiencia Provincial de Barcelona, por esta y otras agresiones, a distintas penas así como a indemnizar a los herederos (sic) de Dña. Regina en 25 millones de pesetas (si bien la sentencia civil no lo aclara, parece que puede presumirse que el condenado no pagó tal cantidad, al no suscitarse en ningún momento la posible duplicidad indemnizatoria en relación con las acciones que luego se ejercitarán en vía civil contra otros potenciales responsables civiles de los daños).

${ }^{155}$ MCLAUGHLIN/MUNCIE, The Sage Dictionary of Criminology, cit. nota nº 5, p. 384. 
AGUSTINA, JOSÉ R. "Fenomenología del employee crime: Bases para definir Estrategias de prevención del delito intraempresarial".

En 1996 D. José Luis, en su propio nombre y en el de sus dos hijos menores, demanda a Ferrocarril Metropolità de Barcelona, S.A., entidad titular del servicio de ferrocarril suburbano de Barcelona, y a Protecsa, S.A., sociedad que había asumido contractualmente el servicio de seguridad de las instalaciones del metro, reclamando una indemnización de 40 millones de pesetas. Tanto el Juzgado de Primera Instancia como la Audiencia Provincial de Barcelona absolvieron a ambas demandadas". ${ }^{156}$

Sin embargo, el Tribunal Supremo resolvió el recurso de casación de los demandantes condenando a Ferrocarril Metropolità de Barcelona, S.A. a indemnizar en la cuantía pedida en la demanda - y manteniendo la absolución en lo relativo a Protecsa, S.A.-Dos son las cuestiones jurídicas que, esencialmente, ocupan el razonamiento judicial. En cuanto a la primera cuestión relevante que se plantea el Tribunal Supremo, la relativa al (1) ámbito espacio-temporal de los deberes de protección de la empresa de transporte metropolitano en relación con los viajeros, el Tribunal acoge la "doctrina de los deberes de protección" en el contrato, según la cual, junto a los estrictos deberes contractuales de prestación, existen ciertos deberes adicionales entre los contratantes. ${ }^{157}$ Con independencia de cual sea el punto de apoyo teórico o conceptual de tales deberes, parece claro que las empresas de transporte no pueden eludir, sin más, toda responsabilidad por lo que ocurre en las antesalas, vestíbulos, o espacios anejos -o de necesario uso previo- a la utilización en sí de los vehículos que se emplean para el transporte. ${ }^{158}$ En la segunda cuestión se plantea (2) la delimitación de la posición de garante en relación con los daños dolosos de los que el viajero pueda ser objeto en conexión con el contrato de transporte. ${ }^{159}$ Es esta cuestión la que suscita mayor complejidad en su fundamentación jurídica.

Como sostiene Gómez Pomar, el punto de partida en el análisis debiera ser, en términos teóricos, el criterio de la "prohibición de regreso" en la imputación objetiva -relevante, según matiza, tanto en sede de responsabilidad penal como en sede de responsabilidad civil-. De acuerdo con un importante sector de la doctrina civilista española, la prohibición de regreso veda el retroceso en el decurso de causalidad que media entre el comportamiento - de ordinario, la omisión de una conducta que podría haber conducido a quebrar el curso causal- del demandado y el resultado de daño que deriva de la conducta ilícita -dolosa, de ordinario, aunque en ocasiones también

\footnotetext{
${ }^{156}$ Relato fáctico extraído del comentario de la sentencia realizado por GÓMEZ POMAR, F., El guardián del viajero: la posición de garante de las empresas de transporte, 2005, p. 3, de donde proceden buena parte de las consideraciones subsiguientes.

157 Tales deberes complementarios o laterales consisten en evitar a la otra parte contratante consecuencias negativas en su esfera personal o patrimonial y que pueden derivar de la puesta en riesgo o peligro de los bienes jurídicos de la contraparte que provoca el contacto social resultante de la relación contractual entre los interesados.

${ }^{158}$ Como apunta Gómez Pomar, en Alemania se ha discutido largamente acerca de si el fundamento de la responsabilidad por vulneración de deberes de protección se encuentra en la responsabilidad extracontractual o delictual general, si en una relación social especial (Sonderverbindung), en la posibilidad de interferencia especial en bienes ajenos (besondere Einwirkungsmöglichkeit), en la responsabilidad por confianza (Anvertrauenshaftung), en una responsabilidad delictual especial (Sonderdelikt), etc. Actualmente, los deberes contractuales de protección tienen un fundamento legal expreso tras la reforma del Derecho de obligaciones en Alemania (vid. § 241.2 BGB).

${ }^{159}$ Vid. GÓMEZ POMAR, El guardián del viajero, cit. nota ${ }^{\circ} 156$.
} 
negligente- de un sujeto distinto del demandado y que "no se halla legalmente bajo la supervisión o control" de este último. ${ }^{160}$

Sin embargo, no queda el demandado exento de responsabilidad por el resultado dañoso en el que intervino el dolo o la culpa de un tercero cuando aquél ocupaba una posición de garante encaminada a lograr la indemnidad de los bienes o intereses que finalmente han quedado afectados. Citando a Jakobs, se argumenta que la posición de garante no es el producto exclusivo de situaciones y titularidades jurídicas, sino que depende de un complejo y variopinto conjunto de factores: el comportamiento previo del agente en cuanto al curso causal, la existencia de deberes legales o sociales de actuación, las posibilidades efectivas de control de dicho curso causal, la posición de organización del agente, etc. Así, la existencia de una competencia o un deber jurídico general de actuación no son bastantes para fundar la imputación objetiva de un resultado dañoso puesto en marcha por un tercero y que el titular de la competencia o sujeto del deber no ha evitado o aminorado: las Administraciones Públicas competentes en materia de seguridad ciudadana no son, por este simple hecho, responsables de los daños que deriven de acciones terroristas o actos de delincuencia común.

Desde un punto de vista material, un deber genérico guarda relación con la protección de un bien jurídico in genere, sin la necesidad de que responda a peligros específicos con un nivel de probabilidad alto. En cambio, un deber preciso suele dirigirse a evitar un riesgo estadísticamente previsible respecto de ciertas fuentes de peligro.

Un deber genérico de protección de la indemnidad del viajero no es condición suficiente, por tanto, para fundamentar la responsabilidad civil de la empresa transportista, en tanto que no se trata de ni de un deber abstracto ni incondicionado. Los deberes de protección, en efecto, no equivalen sin más a posición de garante a los efectos de la imputación objetiva del resultado dañoso, aunque, sin duda, constituyen un factor relevante para calificar la posición del transportista como de una verdadera posición de garante. Sin embargo, tales deberes de protección no son ilimitados, sino que la extensión del deber ha de ser proporcionada al riesgo de daño que el contacto entre las partes derivado del contrato de transporte ha creado. A sensu contrario, la posición de garante general supondría convertir al transportista en "asegurador universal de los infortunios que puedan tener lugar en los entornos temporales y físicos del contrato de transporte". ${ }^{161}$

En este sentido, a efectos de restringir el alcance de un deber exorbitante de responsabilidad en el marco del "deber de protección de la indemnidad del viajero", es preciso preguntarse si las conductas de evitación del resultado omitidas por la empresa de transportes han incidido, de forma negativa, en el riesgo preexistente de daño. Cuando aquéllas no han aumentado de forma significativa el riesgo subyacente del resultado de lesión, no debiera afirmarse la imputación objetiva de tal resultado a la empresa, a pesar de estar sujeta a deberes de protección. En cambio, cuando las medidas pudieran haber tenido, en abstracto, "eficacia reductora del coste de daño

\footnotetext{
${ }^{160}$ Así, SALVADOR CODERCH, P., Causalidad y responsabilidad, 2002; PANTALEÓN PRIETO, F., Causalidad e imputación objetiva, Libro Centenario del Código civil, Tomo II, Madrid, 1990, pp. 1561-1591 (vid. GÓMEZ POMAR, El guardián del viajero, cit. nota ${ }^{\circ} 156$, p. 3).

${ }^{161}$ GÓMEZ POMAR, El guardián del viajero, cit. nota ${ }^{\circ} 156$, p. 8.
} 
AGUSTINA, JOSÉ R. "Fenomenología del employee crime: Bases para definir Estrategias de prevención del delito intraempresarial".

esperado del resultado", la posición de garante debiera encontrarse justificada, y con ella, la imputación objetiva al demandado. En otras palabras, la determinación de la posición de garante debe asociarse en sustancia al criterio de la virtualidad reductora ex ante del riesgo de daño. ${ }^{162}$

La Sala $1^{\text {a }}$ del Tribunal Supremo ha defendido, en situaciones análogas a las de la sentencia que se comenta, posiciones curiosamente bastante alineadas con esta visión: STS, 1a, 23-12-1997 (ponente González Poveda) [taquillero de empresa de transportes fallecido a resultas de las heridas causadas en un robo a mano armada en las dependencias de la empresa: el Tribunal Supremo entiende que el daño no le es imputable a la empresa, pues más medidas razonables de seguridad no pueden afectar sustancialmente al riesgo de una acción violenta de delincuentes profesionales].

Ciertamente las medidas deseables o exigibles de prevención situacional frente a riesgos específicos variarán según el tipo de actividad empresarial. Sin embargo, el nivel de aversión al riesgo presente en una sociedad tiene un efecto multiplicador, ${ }^{163}$ tendencia -en ocasiones, cargada de subjetivismo- que requiere una tarea de objetivación de las necesarias pautas o expectativas sociales en cada ámbito o sector, de forma que se encuentren políticas equilibradas y razonables. Así, se pueden establecer medidas de vigilancia y control específicas sobre información sensible de la compañía, sin descartar que el control genérico sobre los movimientos y comunicaciones en el entorno tecnológico de la empresa puedan aportar-mediante la correlación entre mensajes, movimientos e incidencias registradas- información valiosa al respecto.

A este respecto, la OIT establece en su Repertorio de recomendaciones (1997) -vid. art. 5.4- que para garantizar la seguridad y el adecuado funcionamiento de los sistemas de información, se requieren medidas de orden técnico y de organización con respecto a su uso (vid. asimismo la sección séptima de dicho documento). Tales medidas comprenden, no obstante, "una vigilancia permanente, en particular de todas las personas que trabajan en los servicios informáticos". La OIT señala que en todas las reglamentaciones internacionales y nacionales que restringen el uso de datos personales existen reglas que establecen estas medidas para una eficiente protección de los datos y, probablemente, la introducción de tales medidas es "uno de los pocos casos en que se reconoce como indispensable la vigilancia continua de los trabajadores". Sin embargo, esta vigilancia prácticamente ilimitada debe compensarse mediante una limitación muy estricta de los usos que se hacen de los datos a los que se tiene acceso mediante tales medidas.

\footnotetext{
${ }^{162}$ GÓMEZ POMAR, El guardián del viajero, cit. nota n ${ }^{\circ} 156$, p. 8. Sustancialmente ésta es la visión desde el análisis económico del Derecho del conjunto de indicaciones agrupadas bajo las denominaciones de imputación objetiva -en la terminología de los sistemas continentales en los que se ha sentido, en mayor o menor grado, la influencia de la teoría del delito alemana- o proximate causation -en los sistemas de Common Law- (vid. SHAVELL, Steven (1998), "Causation", en: NEWMAN, Peter (ed.), The New Palgrave Dictionary of Economics and the Law, London-New York).

${ }^{163}$ En relación a la "institucionalización de la inseguridad", la incertidumbre en la vida social y la descripción del estado actual como el de una sociedad de la "inseguridad sentida", vid. SILVA SÁNCHEZ, La expansión del Derecho penal, cit. nota $\mathrm{n}^{\circ}$ 90, p. 32 y ss.
} 
Aunque advierta la OIT que dichos datos deben ser procesados únicamente para cumplir la finalidad para la cual se establece la vigilancia, es decir, el correcto funcionamiento del sistema $-\mathrm{y}$ que por tanto no deben utilizarse para controlar o vigilar el comportamiento y los desplazamientos de los trabajadores-introduce una excepción a renglón seguido. Así, se afirma que esta regla "no es aplicable a los casos en donde, por ejemplo, una persona que trabaje en un centro de informática haya infringido reglas de seguridad y los datos se procesen con fines disciplinarios. Este uso es perfectamente compatible con los fines para los cuales se han reunido los datos". Y concluye legitimando de forma extensa lo que podría denominarse la doctrina del hallazgo casual en el ámbito de la empresa: ${ }^{164}$ "dado que el propósito principal de esta disposición es el de prohibir un control permanente por medio de medidas de seguridad, el descubrimiento accidental de infracciones no relacionadas con el objetivo de las medidas no estaría en general sometido a esta restricción".

Considérese a este respecto la mayor capacidad de detección de una organización que se enfrenta a la comisión de un delito -en relación con los rastros informáticos que inevitablemente dejan todos los trabajadores-, cuando los incidentes se analizan y correlacionan en el conjunto del entorno de sistemas de la empresa (effective pattern detection: correlating messages and events across the IT environment). Así por ejemplo, una organización puede implementar una aplicación sensible a la que generalmente no se deba acceder a distancia. Si un trabajador accede sin haber pasado a través de puntos de acceso físico -como puede ser un lector de identificadores (badge reader) - un sistema integrado puede identificar de forma inmediata ese comportamiento como algo inusual y potencialmente peligroso. Sin esta correlación automática en tiempo real, el acceso remoto no puede detectarse lo suficientemente rápido. Un retraso -aunque tan sólo sea por unas horas- puede proporcionar una amplia ventana de oportunidades para alguien que quisiera atacar el sistema. ${ }^{165}$

\section{Consideraciones finales}

En primer lugar se ha analizado la fenomenología del delito perpetrado por quienes forman parte de una empresa u organización. La génesis de lo que hemos denominado employee crime, así como su finalidad, responde a una lógica distinta a la de los delitos de empresa (corporate crime), en los que la persona jurídica o corporación es la principal beneficiaria del hecho delictivo.

El perfil laboral y la posición que ocupa el empleado en el seno de la organización arroja mucha luz sobre las causas y ocasiones-para-el-delito que, desde el punto de vista preventivo, los responsables de la compañía no deberían despreciar. En este ámbito se revela de suma importancia el análisis pormenorizado y la obtención de información que la empresa lleve a cabo para disminuir los riesgos criminológicos derivados de la deslealtad del trabajador, o de su mera falta de motivación o vinculación con la empresa.

\footnotetext{
${ }^{164}$ Como es lógico, las restricciones en la finalidad de los registros y la investigación pública -ámbito en el que nació la doctrina del hallazgo casual- guardan escasa identidad de razón con las medidas de control y vigilancia en la empresa.

${ }^{165}$ Vid. "Stopping insider attacks: how organizations can protect their sensitive information", Security and privacy, IBM, September 2006, pp. 8-9.
} 
AGUSTINA, JOSÉ R. "Fenomenología del employee crime: Bases para definir Estrategias de prevención del delito intraempresarial".

Con todo, las estrategias preventivas no pueden obviar, a costa de llegar a ser contraproducentes, el factor humano. Los límites éticos, más aún, la gestión éticamente adecuada del capital humano y de los problemas e incidentes en la vida comunitaria de la empresa pueden resultar decisivos en la misma productividad de la compañía y en la satisfacción de los empleados. Sobre estos aspectos he profundizado en otro lugar. ${ }^{166}$

Junto a ello, las estrategias de prevención de riesgos criminológicos en la empresa son terreno más que abonado para la generación de delitos por parte de quienes gobiernan, delitos que, las más de las veces, consistirán en la violación de la intimidad o privacidad de sus subordinados. Sin duda, la cultura del control en la empresa, en el marco general de la sociedad de riesgos en que vivimos, está necesitada del contrapeso necesario que se deriva de la dignidad humana del trabajador. Por todo ello, más que nunca se necesita un enfoque integrador, interdisciplinar, que fomente un gobierno de la empresa en el que se tenga en cuenta que ésta no deja de ser nunca una comunidad de personas.

\footnotetext{
166 AGUSTINA SANLLEHÍ, José R., "El factor confianza y la lógica del control en la empresa: algunas reflexiones ético-jurídicas a propósito de las estrategias de prevención del delito de los trabajadores", Revista Empresa y Humanismo, XII, núm. 2, 2009, pp. 13-60.
} 
Polit. crim. Vol. 5, No 10 (Diciembre 2010), Art. 3, pp. 352-409.

[http://www.politicacriminal.cl/Vol_05/n_10/Vol5N10A3.pdf]

\section{BIBLIOGRAFÍA}

AGUSTINA SANLLEHÍ, J.R., "Estrategias de reacción frente al delito. A propósito del delito intraempresarial", Revista de Derecho Penal y Criminología, $3^{\mathrm{a}}$ Época, 2010, núm. 3, pp. 299-337.

AGUSTINA SANLLEHÍ, J.R., El delito en la empresa., Barcelona: Atelier, 2010.

ALDER, G.S., "Ethical Issues in Electronic Performance Monitoring: A Consideration of Deontological and Teleological Perspectives", Journal of Business Ethics 17: 729-743, 1998.

ALldRIDGE, P., BRANTS, C., Personal Autonomy, the Private Sphere and the Criminal Law. A Comparative Study, Oxford, 2001.

ALLEN, F.A., "The Morality of Means: Three Problems in Criminal Sanctions", 42 University of Pittsburg Law Review 737, 738 (1981).

AUSTRALIAN INSTITUTE OF CRIMINOLOGY, Crime against business: A review of victimisation, predictors and prevention, (Vol. 11), Canberra, Australia, 2004.

BARCELÓ DOMÉNECH, J., Responsabilidad extracontractual del empresario por actividades de sus dependientes, McGraw-Hill, 1995

BARNES, P., LAMBELL, J., Organisational Susceptability to Fraud: Does Fraud Strike Randomly or Are There Organisational Factors Affecting its Likelihood and Size?, Working Paper, Nottingham Business School, (2002).

BECKER, G., "Crime and punishment: an economic approach", Journal of Political Economy, 76, (1968), pp. 169-267.

BEN-YEHUDA, N., Betrayal and treason: violations of trust and loyalty, 2001.

BERNSTEIN, J., HOUSTON, E., Crime and Work. What we can learn from the lowwage labor market, 2000.

BIRKS, P. (ed.), Privacy and Loyalty, Oxford: Clarendon Press, 1997.

BLANPAIN, R. (ed.), On-line Rights for Employees in the Information Society. Use and Monitoring of E-mail and Internet at Work, Brussels 13-14 November 2000. Proceedings of the Conference by the Royal Flemish Academy of Belgium for Science and the Arts, Union Network International, UNI-Europa, The Euro-Japan Institute for Law and Business, Bulletin of Comparative Labour Relations 40-2002.

BLOUNT, E.C., Occupational Crime. Deterrence, Investigation, and Reporting in Compliance with Federal Guidelines, Florida, 2003.

BOLOGNA, J., SHAW, P., Corporate Crime Investigation, Washington, 1997.

BOOKMAN, Zachary F., "Convergences and Omissions in the Reporting of Corporate and White Collar Crime", Yale Law School Student Scholarship Series, 2007, paper 43. Disponible en http://1sr.nellco.org/yale/student/papers/43

BRAITHWAITE, J., Corporate Crime in the Pharmaceutical Industry, London, 1984.

BROWN, W.S. (1996). "Technology, workplace privacy, and personhood", Journal of Business Ethics, 15, 1237-1248.

BRISEBOIS, R., "Sobre la confianza", Cuadernos Empresa y Humanismo, Vol. 65, Pamplona, 1997.

BRUCE, A., FORMISAND, R., Building a high-morale workplace, New York, 2003.

BUSSMANN, K.-D., "Causes of Economic Crime and the Impact of Values: Business Ethics as a Crime Prevention Measure", paper presented at the Swiss Conference on Coping with Economic Crime. Risks and Strategies, Zurich, 2003. 
AGUSTINA, JOSÉ R. "Fenomenología del employee crime: Bases para definir Estrategias de prevención del delito intraempresarial".

BUSSMANN, K.-D., WERLE, M.M., "Addressing Crime in Companies. First Findings from a Global Survey of Economic Crime", British Journal of Criminology $\mathrm{N}^{\mathrm{o}}$ 46, (2006), 1128-1144.

BYRNE, J.M., REBOVICH, D.J., The new technology of crime, law and social control, Monsey, NY: Criminal Justice Press, 2007.

CABEZUELO ARENAS, A.L., Derecho a la intimidad, Valencia, 1998.

CID MOLINÉ, J., LARRAURI PIJOAN, E., Teorías criminológicas. Explicación y prevención de la delincuencia, Barcelona, 2001.

CLARKE, R.V., Situational Crime Prevention: Successful Case Studies, New York, 1992.

CLARKE, R.V., "Situational Crime Prevention", Crime and Justice No 91 (1995).

CLARKE, R.V., "Opportunity-based Crime Rates", British Journal of Criminology, 1984, 24:74-83.

CLUTTERBUCK, D., S. CRAINER, Los maestros del management. Hombres que llegaron más lejos. Barcelona: Grijalbo, 1991.

COFFEE, J.C., JR, Gatekeepers: The Professions and Corporate Governance, Oxford, 2006.

COHEN, L.E., FELSON, M. (1979) "Social change and crime rate tends: a routine activities approach", American Sociological Review No 44, pp. 588-608.

COLE, E., RING, S., Insider Threat: Protecting the Enterprise from Sabotage, Spying, and Theft, 2006.

COLEMAN, JAMES W., The Criminal Elite, New York, 1989.

CRUZ CRUZ, J., Valores éticos, Cuadernos Empresa y Humanismo, Vol. 50, Pamplona 1995.

DAVIS, P., FRANCIS, P., JUPP, V., "Crime-Work Connections: Exploring the 'Invisibility' of Workplace Crime”, en: DAVIS, P., FRANCIS, P., JUPP, V., Invisible Crimes. Their Victims and their Regulation, London, 1999, pp. 54-74.

DE VICENTE PACHÉS, F., El Derecho del Trabajador al Respeto de su Intimidad, Madrid, 1998.

DICKENS, W.T., KATZ, L.F., LANG, K., SUMMERS, L.H., "Employee crime and the monitoring puzzle", Journal of Labour Economics No 7, (1989), pp. 331347.

DODD N.J., “'Troublemaker' and 'Nothing to Lose' Employee Offenders Identified from a Corporate Crime Data Sample", Crime Prevention and Community Safety: An International Journal 2004, 6 (3), 23-32.

DOUGLAS, M., Cultural Bias, London, 1978.

DOUGLAS, M., ISHERWOOD, B., The World of Goods: Towards an Anthropology of Compsumption, Harmondsworth, 1978.

DOUGLAS, M., Natural Symbols, London, 1970.

DUFF, R.A., Answering for Crime. Responsability and Liability in the Criminal Law, Oxford, 2007.

DUFF, R.A., GREEN, S.P., Defining Crimes. Essays on the Special Part of the Criminal Law, Oxford, 2005.

ECK, J.E., "Do premises liability suits promote business crime prevention?" en: FELSON, M., CLARKE, R.V. (eds.), Business and Crime Prevention, New York, 1997, pp. 125-150.

ETZIONI, A., The limits of privacy, New York, 1999.

EVERETT, A.M., WONG, Y.-Y., PAYNTER, J., "Balancing employee and employer rights: an international comparison of e-mail privacy in the 
Polit. crim. Vol. 5, № 10 (Diciembre 2010), Art. 3, pp. 352-409.

[http://www.politicacriminal.cl/Vol_05/n_10/Vol5N10A3.pdf]

workplace", Journal of Individual Employment Rights, Vol. 11(4) 291-310, 2004-2005 (2006).

FALGUERA BARÓ, M.A., "Trabajadores, empresas y nuevas tecnologías”, artículo publicado en Cuadernos y Estudios de Derecho Judicial, de 2004, pp. 187-221.

FELSON, M., Crime and Everyday life. Insights and Implications for Society, California, 1994.

FELSON, M., CLARKE, R.V. (eds.), Business and Crime Prevention, New York, 1997.

FELSON, M., CLARKE, R.V., "La ocasión hace al ladrón. Teoría práctica para la prevención del delito" (trad. de M. DÍAZ I PONT y D. FELIP I SABORIT), Police Research Series, Paper 98. Home Office, Policing and Reducing Crime Unit, London 1998.

FELSON, M., "Technology, Business and Crime", en: FELSON, M., CLARKE, R.V. (eds.), Business and Crime Prevention, New York, 1997.

FENNELLY, L.J., Handbook of loss prevention and crime prevention, Burlington, MA: Elsevier Butterworth-Heinemann, 2004.

FINKIN, M.W., "Employee Privacy and the 'Theory of the Firm'”, Journal of Labor Research, Volume XXVI, No 4, Fall 2005, pp. 711-723.

FINKIN, M.W., 'Information Technology and workers' privacy: the United States Law", en: JEFFERY, M., "Information Technology and workers' privacy: a comparative study", Comparative Labor Law \& Policy Journal, volume 23, N ${ }^{\circ}$ 2, 2002.

FISHMAN, C.S., MCKENNA, A.T., Wiretapping \& Eavesdropping: Surveillance in the Internet Age, $3^{\text {rd }}$ ed., 2007.

FLETCHER, G.P., Loyalty. An Essay on the Morality of Relationships, Oxford, 1993.

FOLLETT, M.P., Creative experience. New York: Peter Smith, 1971.

FONTRODONA FELIP, J. Y GARCÍA CASTRO, R., Estudio sobre politicas, hábitos de uso y control de Internet y correo electrónico en las principales empresas 2002, españolas, disponible en http://www.iese.edu/es/files/5 6604.pdf

FORD, M., "Two Conceptions of Worker Privacy", Industrial Law Journal, Vol. 31, $\mathrm{N}^{\mathrm{o}}$ 2, June 2002, pp. 135-155.

FRANKEL, T., Trust and Honesty. America's Business Culture at a Crossroad, Oxford, 2006.

FRIEDRICHS, D.O., "Occupational crime, occupational deviance, and workplace crime: Sorting out the difference", Criminal Justice, Vol. 2, No 3, 243-256 (2002).

GARCÍA RUIZ, P., "La lógica del directivo: el control necesario y la confianza imposible", Cuadernos Empresa y Humanismo, Vol. 47, Pamplona, 1994.

GARLAND, D., La cultura del control (trad. de M. SOZZO), Barcelona, 2005.

GEIS, G., "El delito de cuello blanco como concepto analítico e ideológico", en: Derecho Penal y Criminología como fundamento de la política criminal. Estudios en homenaje al profesor Alfonso Serrano Gómez, 2006.

GILL, M., Crime at Work: Studies in Security and Crime Prevention, Leicester, UK, 1994.

GILL, M., The handbook of security, 2006.

GILlIOM, J., Surveillance, Privacy, and the Law. Employee Drug Testing and the Politics of Social Control, Estados Unidos: University of Michigan Press, 1994.

GÓMEZ POMAR, F., "El guardián del viajero: la posición de garante de las empresas de transporte" (comentario a la STS, $1^{\mathrm{a}}, 20.12 .2004$ ), InDret $2 / 2005$. 
AGUSTINA, JOSÉ R. "Fenomenología del employee crime: Bases para definir Estrategias de prevención del delito intraempresarial".

GOOLD, BENJAMIN J., "Privacy rights and public spaces: CCTV and the problem of the unobservable observer", Criminal Justice Ethics, vol. 21, no. 1, pp. 2127, 2002.

GRAY, G.C., "The Regulation of Corporate Violations. Punishment, Compliance, and the Blurring of Responsibility", British Journal of Criminology $\mathrm{N}^{\mathrm{o}} 46$ (2006), pp. 875-892.

GREEN, G.S., Occupational Crime, Second Edition, Chicago, 1997.

GREEN, S.P., Lying, Cheating, and Stealing. A Moral Theory of White-Collar Crime, Oxford University Press, 2006.

GUERIN, L., Workplace Investigations: a step by step guide, 2004.

GUILLÉN, M., "La Ética empresarial: una aproximación al fenómeno", Cuadernos Empresa y Humanismo, Vol. 58, Pamplona, 1996.

GUP, B.E., Targeting Fraud. Uncovering and Deterring Fraud in Financial Institutions, First edition 1990, Chicago, 1995.

HAERLE, CINDY M., "Employer Liability for the Criminal Acts of Employees Under Negligent Hiring Theory: Ponticas v. K.M.S. Investments," Minnesota Law Review, Vol. 68: 1303-1326.

HAGGERTY, K.D., ERICSON, R.V., The New Politics of Surveillance and Visibility, University of Toronto Press, 2006.

HARFIELD, C., HARFIELD, K., Covert Investigation, Oxford, 2006.

HARRIS, P.M., KELLER, K. S., "Ex-offenders need not apply: The criminal background check in hiring", Journal of Contemporary Criminal Justice, vol. 21, No 1 (2005), pp. 6-30.

HENDRICKX, F., Employment Privacy Law in the European Union: Surveillance and Monitoring, Antwerp-Oxford-New York, 2002.

HENRY, S., Can I Have It In Cash? A Study Of Informal Institutions and Unorthodox Ways of Doing Things, London, 1981.

HOME OFFICE RESEARCH, Public attitudes towards CCTV: Results from the preintervention public attitude survey carried out in areas implementing CCTV, Development and Statistics Directorate, London, United Kingdom, 2005.

HUNTER, R., World Without Secrets: Business, Crime and Privacy in the Age of Ubiquitous Computing, 2002.

INFESTAS GIL, Sociología de la empresa, Salamanca, 1991.

JAKOBS, G., La imputación objetiva en Derecho Penal, (trad. GONZÁLEZ SUÁREZ, CANCIO MELIÁ), 1996.

JAKOBS, G., Derecho Penal. Parte General. Fundamentos y teoría de la imputación, $2^{\circ}$ ed., Madrid, 1997.

JEFFERY, M., "Information Technology and workers' privacy: a comparative study." Comparative Labor Law \& Policy Journal, volume 23, No 2 (2002).

JEFFERY, M., ¿Carta Blanca para espiar a los trabajadores? Perspectivas inglesas sobre poder informático e intimidad. Ponencia presentada el 30 de marzo de 2001 en el Seminario "Poder informático e intimidad: límites jurídico-laborales y penales al control empresarial", organizado por los Estudios de Derecho y Ciencias Políticas de la UOC.

JUPP, V.R., DAVIS, P., FRANCIS, P., "The features of Invisible Crimes" en: DAVIS, P., FRANCIS, P. AND JUPP, V.R., Invisible Crimes. Their Victims and their Regulation, London, 1999.

KADLECK, C., "Police employee organizations", Policing: An International Journal of Police Strategies \& Management, vol. 26, No 2 (2003), pp. 341-351. 
Polit. crim. Vol. 5, № 10 (Diciembre 2010), Art. 3, pp. 352-409.

[http://www.politicacriminal.cl/Vol_05/n_10/Vol5N10A3.pdf]

KATYAL, N.K., "Digital Architecture as Crime Control", 111 Yale Law Journal 1039 (2002).

KELling, G.L., COLES, C.M., Fixing Broken Windows: Restoring Order and Reducing Crime in Our Communities. New York: Touchstone Books, 1996.

KIDWELL, R.E., MARTIN, C.L. (eds), Managing organizational deviance, 2005.

KUPRITZ, F.J., et altri, "Privacy in the workplace: the impact of building design", Journal of Environmental Psychology, 18 (1998), pp. 341-356.

LANE III, F.S., The naked Employee. How technology is compromising workplace privacy, New York, 2003.

LARSSON, P., "Soft and hard strategies of regulating economic crime", Journal of Financial Crime, Vol. 14, No 2 (2007), pp. 209-220.

LASPROGATA, G., KING, N.J., PILLAY, S., "Regulation of electronic employee monitoring: identifying fundamental principles of employee privacy through a comparative study of data privacy legislation in the European Union, United States and Canada", 2004 Stanford Technology Law Review 4. Artículo disponible en Internet en http://stlr.stanford.edu/pdf/LasprogataRegulationElectronic.pdf

LITTON, R.A., "Crime Prevention and Insurance", The Howard Journal of Penology and Crime Prevention, 1982, 21:6-22.

LITTON, R.A., "Crime Prevention and the Insurance Industry", en: FELSON, M., CLARKE, R.V. (eds.), Business and Crime Prevention, New York, 1997, pp. 151-195

LLEBOT MAJO, J.O., Los deberes de los administradores de la Sociedad Anónima, Madrid, 1996.

LOCKER, J.P., GODFREY, B., "Ontological Boundaries and Temporal Watersheds in the Development of White-Collar Crime", British Journal of Criminology $\mathrm{N}^{\mathrm{o}}$ 46 (2006), pp. 976-992.

LORENTE, J., El uso laboral y sindical del correo electrónico e Internet en la empresa. Aspectos constitucionales, penales y laborales, Valencia, 2007.

LUHMANN, N., Confianza, (trad. FLORES, Amada), Santiago de Chile, 2005.

LUHMANN, N., Sociedad, norma y persona en una teoría de un Derecho penal funcional, trad. M. CANCIO MELIÁ Y B. FEIJOO SÁNCHEZ), Madrid, 1996.

LUQUE PARRA, M., Los límites jurídicos de los poderes empresariales en la relación laboral, Zaragoza, 1999.

LYON, D., Surveillance as Social Sorting. Privacy, risk, and digital discrimination, London, 2003.

MANSELL, R., COLLINS, B.S., Trust and crime in information societies, Cheltenham: Edward Elgar, 2005.

MARCHENA GÓMEZ, M., "Dimensión jurídico-penal del correo electrónico", Diario La Ley, n. 6475, 4 de mayo de 2006, ref. D-114.

MARÍN DE ESPINOSA CEBALLOS, E., Criminalidad de empresa, Valencia, 2002.

MARMOR, R.I., TOMAINE, J.J., Commercial Crime Policy, Chicago, 2005.

MARS, G., Cheats at Work. An Anthropology of Workplace Crime, London, 1982.

MCCAHILL, M., NORRIS, C., "Watching the workers: Crime, CCTV and the Workplace", en: DAVIS, P., FRANCIS, P., JUPP, V., Invisible Crimes. Their Victims and their Regulation, London, 1999, pp. 208-231.

MCCAHILL, M., The Surveillance Web. The rise of visual surveillance in an English city, USA-Canada, 2002.

MCLAUGHLIN, E., MUNCIE, J., The Sage Dictionary of Criminology, reprinted 2007. 
AGUSTINA, JOSÉ R. "Fenomenología del employee crime: Bases para definir Estrategias de prevención del delito intraempresarial".

MCNEIL, B.F., BRIAN, B.D. (eds.), Internal Corporate Investigations, (third edition), Chicago, 2007.

MEDINA ARIZA, J.J., "El control social del delito a través de la prevención situacional", Revista de Derecho Penal y Criminología, núm. 2 (1998), pp. 281323.

MONKS, ROBERT A.G., MINOW, N., Corporate Governance, 1995, Massachussets, 2000.

MORRIS, G.S., "Fundamental Rights: Exclusion by Agreement?", Industrial Law Journal, Vol. 30, № 1 (Marzo 2001), pp. 49-71.

NAGEL, T., "Concealment and Exposure", Philosophy \& Public Affairs, Vol. 27, No 1 (winter 1998), pp. 3-30.

NAGIN, D.S., PATERNOSTER, R., REBITZER, J.B., SANDERS, S., TAYLOR, L.J., "Monitoring, motivation, and management: the determinants of opportunistic behaviour in a field experiment", American Economic Review (2002), 92, pp. 850-873.

NEMESIO RUIZ, “Organización de la empresa”, en: Organización y Trabajo: Temas de Sociología de la Empresa, Valencia, 1992, pp. 15 y ss.

NOUWT, S., DE VRIES, B.R., PRINS, C., Reasonable Expectations of Privacy? Eleven Country Reports on Camera Surveillance and Workplace Privacy, The Netherlands, 2005.

OGBURN, W.F., On Culture and Social Change: Selected Papers, O.D. DUNCAN (ed.), Chicago, 1964.

O'SUlLIVAN, J.R., Federal White Collar Crime, 2nd edition, 2003.

OZ, E., GLASS, R., BEHLING, R., "Electronic workplace monitoring: what employees think", Omega, The International Journal of Management Science No 27 (1999), pp. 167-177.

PASTOR MUÑOZ, N., "La respuesta adecuada a la criminalidad de los directivos contra la propia empresa: ¿Derecho penal o autorregulación empresarial?”, Barcelona, 4/2006, InDret 380.

PAYNE, B.K., GAINEY, R.R., "Ancillary consequences of employee theft”, Journal of Criminal Justice $\mathrm{N}^{\circ} 32$ (2004), pp. 63-73.

PÉREZ LÓPEZ, J.A., "El sentido de los conflictos éticos originados por el entorno en que opera la empresa", Cuadernos Empresa y Humanismo, Vol. 4.

PÉREZ LÓPEZ, J.A., Fundamentos de la Dirección de Empresas, quinta edición, Madrid, 2002.

PHILLIPS, D.J., "Privacy and Data protection in the workplace: the US case", publicado en: NOUWT, S., DE VRIES, BEREND R., PRINS, C., Reasonable Expectations of Privacy? Eleven Country Reports on Camera Surveillance and Workplace Privacy, The Netherlands, 2005, pp. 39-60.

PIÑA ROCHEFORT, J.I., Rol social y sistema de imputación. Una aproximación sociológica a la función del Derecho Penal, Barcelona, 2005.

PIQUERO, N.L., TIBBETTS, S.G., BLAKENSHIP, M.B., "Examining the role of differential association and techniques of neutralization in explaining corporate crime", Deviant Behavior, 26: 159-158, 2005.

PORTER II, W.G., GRIFFATON, M.C., "Between the Devil and the Deep Blue Sea: Monitoring the Electronic Workplace. Employers should have Detailed, Understandable and Fair Computer, E-Mail and Internet Usage Policies Impartially Administered", Defense Counsel Journal, January 2003.

PRENZLER, T., Private investigators in Australia: Work, law, ethics, and regulation, Brisbane, Australia: School of Criminology and Criminal Justice, 2001. 
Polit. crim. Vol. 5, No 10 (Diciembre 2010), Art. 3, pp. 352-409.

[http://www.politicacriminal.cl/Vol_05/n_10/Vol5N10A3.pdf]

RICE, P.R., Electronic Evidence. Law and Practice, Chicago, 2005.

RICKMAN, N., WITT, R., "The Determinants of Employee Crime in the UK", Economica $\mathrm{N}^{\mathrm{o}} 74$ (2007), pp. 161-175.

SCHNATTERLY, K., "Increasing firm value trough detection and prevention of white-collar crime", Strategic Management Journal, 24: 587-614 (2003).

SCHOEMAN, F.D., Privacy and social freedom, Cambridge University Press, 1992.

SCOTT, J.C., Seeing Like a State, New Haven, 1998.

SILVA SÁNCHEZ, J.M., "Criterios de asignación de responsabilidad en estructuras jerárquicas", en: Empresa y delito en el nuevo Código penal, II, Cuadernos de Derecho Judicial. CGPJ Madrid 1997, pp. 9-58.

SIMONS, R., "Strategic orientation and top management attention to control systems", Strategic Management Journal, 12 (1), 1991, pp. 49-62.

SIMPSON, S.S., Corporate Crime, Law, and Social Control, Cambridge, 2002.

SIPIOR, J.C., "Ethical management of employee e-mail privacy", Information Systems Management $\mathrm{N}^{\mathrm{o}} 15$ (1998), pp. 41-47.

SLOBOGIN, C., Privacy at Risk. The New Government Surveillance and the Fourth Amendment, Chicago, 2007.

SNIDER, L., "Cooperative Models and Corporate Crime: Panacea or Cop-Out?", Crime and Delinquency No 36 (1990).

SNIDER, L., "Crimes against capital: Discovering theft of time", Social Justice, vol. 28, No 3 (2001), pp. 105-120.

SOLOVE, D.J., Understanding Privacy, London, 2008.

SPEED, M., "Reducing Employee Dishonesty: In Search of the Right Strategy", en: Managing Security. Crime at Work (Volume III), Leicester, 2003, Chapter 10, pp. 157-179.

STANTON, J.M., STAM, K.R., The Visible Employee. Using workplace monitoring and surveillance to protect information assets without compromising employee privacy or trust, New Jersey, 2006.

STRADER, J.K., JORDON, S., White Collar Crime: cases, materials and problems, Estados Unidos: Lexis Publishing, 2005.

STRADER, J.K., Understanding White Collar Crime, (2nd ed.), Estados Unidos: Lexisnexis, 2006.

SUNDBY, S.E., “Everyman's Fourth Amendment: Privacy or Mutual Trust Between Government and Citizen?", Columbia Law Review No 94 (1994): 1789-1790.

SUTHERLAND, E.H., White-Collar Crime, New York, 1949.

SUTHERLAND, E.H., "White-Collar Criminality", American Sociological Review, Vol. 5, No 1 (Feb. 1940), pp. 1-12.

TAYLOR, N., "State Surveillance and the Right to Privacy", 2002 Surveillance \& Society 1 (1): 66-85.

TRAUB, S.H., "Battling Employee Crime: A Review of Corporate Strategies and Programs", Crime \& Delinquency, Vol. 42 No 2 (April 1996), pp. 244-256.

VON HIRSCH, A., Cuestiones éticas en torno a la vigilancia en espacios públicos mediante cámaras de televisión (trad. de J.R. AGUSTINA SANLLEHÍ), en: VON HIRSCH, A., GARLAND, D., WAKEFIELD, A. (eds), Ethical and Social Perspectives on Situational Crime Prevention, London: Hart, 2000, (publicado en InDret 4/2007).

VON HIRSCH, A., The Ethics of Situational Crime Prevention, ponencia leída como clase magistral de despedida en la Escuela de Justicia Criminal, Rutgers, The State University of New Jersey, en mayo de 1996. 
AGUSTINA, JOSÉ R. "Fenomenología del employee crime: Bases para definir Estrategias de prevención del delito intraempresarial".

VON HIRSCH, A., ASHWORTH, A., "Not Not Just Deserts: A Response to Braithwaite and Pettit", Vol. 12 Oxford Journal of Legal Studies, 83, 1992.

WALTERS, G.J., "Privacy and Security: An Ethical Analysis", Computers and Society (Junio 2001). Extracto del Capítulo 5 de: Human Rights in an Information Age: A Philosophical Analysis, University of Toronto Press, 2001.

WATSON, G., "E-mail surveillance in the UK workplace - a management consulting case study", Aslib Proceedings, Vol. 54, № 1 (2002), pp. 23-40.

WECKERT, J., Electronic monitoring in the workplace: controversies and solutions, 2005.

WEN, H.J., GERSHUNY, P., "Computer-based monitoring in the American workplace: Surveillance technologies and legal challenges", Human Systems Management $\mathrm{N}^{\mathrm{o}} 24$ (2005), pp. 165-173, IOS Press.

WHITAKER, R., El fin de la privacidad (The End of Privacy), 1999.

WIKSTRÖM, P.-O.H., "Personas, entornos y actos delictivos: mecanismos situacionales y explicación del delito", en: VV.AA., Derecho Penal y Criminología como fundamento de la política criminal. Estudios en homenaje al profesor Alfonso Serrano Gómez, 2006.

WIKSTRÖM, P.-O.H., SAMPSON, R.J., The Explanation of Crime. Context, Mechanisms and Development, New York: Cambridge University Press, 2006.

WILDING, E., Information risk and security: preventing and investigating workplace computer crime, 2006.

WILLIAMS, J.W., "Reflections on the private versus public policing of economic crime", British Journal of Criminology No 45 (2005), pp. 316-339.

WILLISON, R., "Understanding the perpetration of employee computer crime in the organizational context", Information and Organization N ${ }^{\circ} 16$ (2006), pp. 304324.

YAR, M., "The Novelty of 'Cybercrime'. An Assessment in Light of Routine Activity Theory”, European Journal of Criminology, Volume 2 (4), 2005, pp. 407-427.

ZUREIK, E., "Theorizing surveillance. The case of the workplace", en: LYON, D., Surveillance as Social Sorting. Privacy, risk, and digital discrimination, London 2003. 